\title{
Alkaline Rock Complexes in the Wet Mountains Area, Custer and Fremont Counties, Colorado
}

GEOLOGIGAL SURVEY PROFESSIONAL PAPER 1269

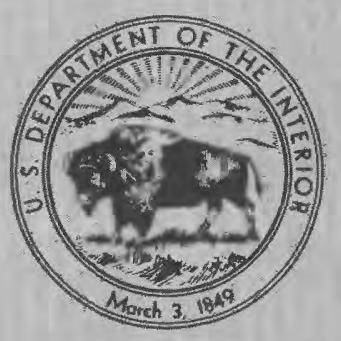




\section{Alkaline Rock Complexes in the Wet Mountains Area, Custer and Fremont Counties, Colorado}

By THEODORE J. ARMBRUSTMACHER

GEOLOG I CAL S URVEY PROFESS1ONAL PAPER 1269

Geology and petrology of rocks of the

McClure Mountain Complex, Gem Park Complex, and complex at Democrat Creek

and associated alkaline rocks

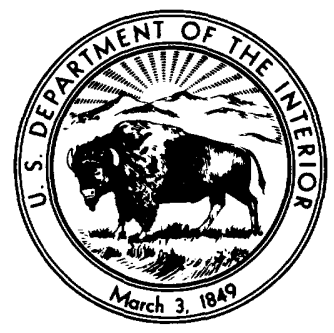

UNITED STATES GOVERNMENT PRINTING OFFICE, WASHINGTON : 1984 


\section{UNITED STATES DEPARTMENT OF THE INTERIOR}

WILLIAM P. CLARK, Secretary

GEOLOGICAL SURVEY

Dallas L. Peck, Director

Library of Congress Cataloging in Publication Data

Armbrustmacher, Theodore J., 1946-

Alkaline Rock complexes in the Wet Mountains area, Custer and Fremont Counties, Colorado.

(Geological Survey Professional Paper 1269)

Bibliography: 33 p.

Supt. of Docs. No.: I 19.16:1269

1. Alkalic igneous rocks. 2. Petrology-Colorado-Wet Mountains. I. Title. II. Series. QE462.A4A76 $552^{\prime} .3$ 82-600104 AACR2 


\section{CONTENTS}

\begin{tabular}{|c|c|c|c|}
\hline & Page & & Page \\
\hline$\ldots \ldots \ldots \ldots \ldots$ & 1 & Ages of the complexes & \\
\hline$\ldots \ldots \ldots \ldots \ldots$ & 1 & Geochemistry ...... & \\
\hline$\ldots \ldots \ldots$ & 1 & Major elements . . . . . . . . . & 15 \\
\hline$\ldots \ldots \ldots$ & 2 & Mafic-ultramafic rocks ..... & 15 \\
\hline IcClure Mountain Complex & 2 & Leucocratic rocks $\ldots \ldots \ldots \ldots$ & 16 \\
\hline nafic rocks & 2 & Mafic nepheline-clinopyroxene rocks & 19 \\
\hline$\ldots \ldots \ldots$ & 2 & Additonal observations . . . . . . . . . & 19 \\
\hline intrusions & 6 & Minor elements $\ldots \ldots \ldots \ldots \ldots$ & \\
\hline Leucocra & 6 & Mafic-ultramafic rocks & 22 \\
\hline yenite $\ldots \ldots \ldots \ldots \ldots \ldots$ & 7 & Leucocratic rocks . . & 2 \\
\hline le-biotite syenite . . . . . . . . . & 8 & Mafic nepheline-clinopyroxene rocks & \\
\hline e-clinopyroxene rocks . . . . . . . . & 10 & Rubidium-strontium systematics and rare-earth- & \\
\hline$x \ldots \ldots \ldots \ldots \ldots \ldots \ldots$ & 1 & element distribution patterns $\ldots \ldots$ & \\
\hline 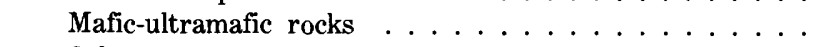 & 12 & Rare-earth elements . . . . . . . . & \\
\hline 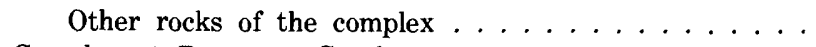 & 12 & Initial ${ }^{87} \mathrm{Sr} /{ }^{86} \mathrm{Sr}$ ratios $\ldots$. & \\
\hline 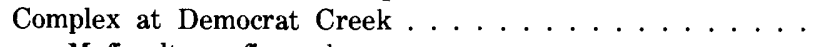 & 12 & Rubidium/strontium ratios . . & \\
\hline he rocks. & 13 & Petrologic conclusions . . . . . . . & \\
\hline Quartz syenite & 13 & References cited ... & \\
\hline Carbonatites $\ldots \ldots \ldots \ldots \ldots$ & & & \\
\hline
\end{tabular}

\section{ILLUSTRATIONS}

FIGURE 1. Map of Wet Mountains area showing location of alkaline complexes . . . . . . . . . . . . . . . .

2. Geologic map of the Wet Mountains area alkaline complexes . . . . . . . . . . . . . . . . .

3. Ternary diagram of modal variation in plagioclase, clinopyroxene, and olivine from the McClure Mountain and Gem

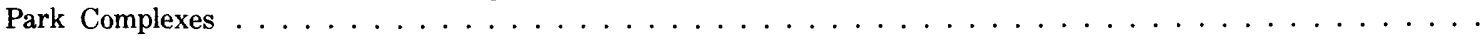

4. Photomicrograph showing adcumulus growth of clinopyroxene on clinopyroxene $\ldots \ldots \ldots \ldots$

5. Photomicrograph of crystallographically oriented iron oxide exsolving from clinopyroxene . . . . . . . . . .

6. Photomicrograph of anorthositic rock with abundant triple-point grain boundaries meeting at $120^{\circ} \ldots \ldots \ldots$

7. Photomicrograph of plagioclase with exsolved iron oxide $\ldots \ldots \ldots \ldots \ldots \ldots$

8. Photomicrograph of abundant cracks between nearby olivine grains . . . . . . . . . . . . . .

9. Photograph of outcrop of mafic-ultramafic rocks cut by nepheline syenite dikes along McClure Gulch . . . . . . . .

10. Photograph of outcrop of nepheline syenite showing heterogeneous nature of grain size and heterogeneous distribution

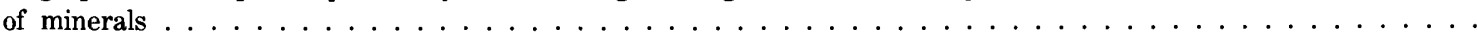

11. Photograph of xenoliths contained in nepheline syenite $\ldots \ldots \ldots \ldots \ldots \ldots \ldots$

12. Photomicrograph of aegirine-augite rimmed by sodic amphibole in nepheline syenite . . . . . . . . . . .

13. Photomicrograph of myrmekitic intergrowth of climopyroxene and nepheline in nepheline syenite ........

14. Quaternary diagram of modal variation in quartz alkali feldspar, plagioclase, and feldspathoid from the McClure Mountain Complex and the complex at Democrat Creek . . . . . . . . . . . . . . . . .

15. Ternary diagram of modal variation in nepheline, mafic minerals, and potassic feldspar from the McClure Mountian

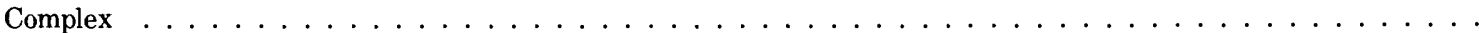

16. Photograph of outcrop of homogeneous hornblende-biotite syenite . . . . . . . . . . . . . .

17. Photomicrograph showing the alteration of clinopyroxene to green amphibole in hornblende-biotite syenite ....

18. Photograph of outcrop of mottled mafic nepheline-clinopyroxene rock . . . . . . . . . . . .

19. Photomicrograph of poikilitic mafic nepheline-clinopyroxene rock $\ldots \ldots \ldots \ldots \ldots$

20. Photograph of cumulus layering in mafic-ultramafic rocks of the Gem Park Complex . . . . . . . . . . . . .

21. Whole-rock isochron of nepheline syenites of McClure Mountain Complex $\ldots \ldots \ldots \ldots$

22. Whole-rock isochron of quartz syenites of the complex at Democrat Creek . . . . . . . . . . . . . .

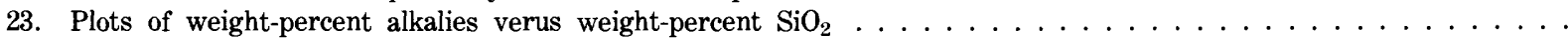

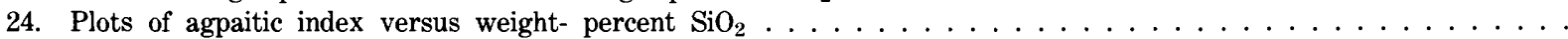

25. Plots of differentiation index (DI) versus oxide weight percents $\ldots \ldots \ldots \ldots \ldots$ 
FiguRE 26. Diagram of chondrite-normalized rare-earth element data for mafic rocks from McClure Mountain Complex and the

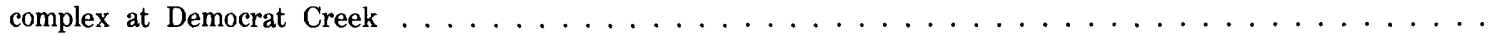

27. Diagram of chondrite-normalized rare-earth element data for liquids from which mafic rocks at the McClure Mountain

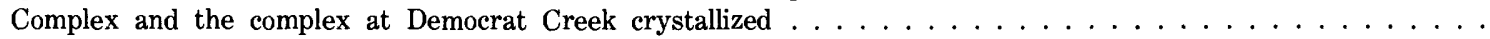

28. Diagram of rare-earth element patterns for hornblende-biotite syenites from the McClure Mountain Complex . . .

29. Diagram of rare-earth element patterns for nepheline syenites from the McClure Mountain Complex ....... .

30. Diagram of rare-earth element patterns for quartz syenites from the complex at Democrat Creek ........

31. Diagram showing distribution of initial ${ }^{87} \mathrm{Sr}{ }^{86} \mathrm{Sr}$ ratios for rocks of the alkaline complexes . . . . . . . . . .

32. Diagram showing rubidium/strontium ratios of rocks from the McClure Mountain Complex . . . . . . . . . . .

33. Diagram showing rubidium/strontium ratios of rocks from the complex at Democrat Creek . . . . . . . . . .

34. Summary of rock distributions in the Wet Mountains area $\ldots \ldots \ldots \ldots \ldots$

\section{TABLES}

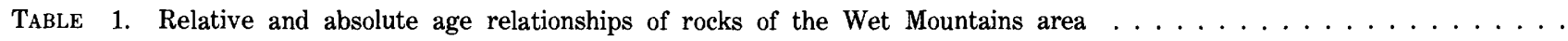

2. Chemical and normative data of mafic-ultramafic rocks from the Iron Mountain area of the McClure Mountain Complex .

3. Chemical and normative data of mafic-ultramafic rocks from the Gem Park Complex and the complex at Democrat Creek .

4. Chemical and normative data of hornblende-biotite syenites, nepheline syenites, and mafic nepheline-clinopyroxene rocks, McClure Mountian Complex . . . . . . . . . . . . . . . . . . . . . . .

5. Chemical and normative data of quartz syenites from the complex at Democrat Creek and nepheline syenite pegmatite

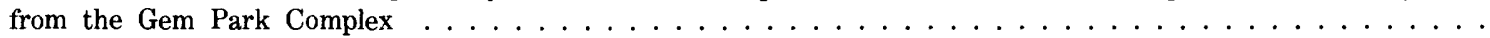

6. Summary of minor-element analyses of samples from the McClure Mountain Complex . . . . . . . . . . .

7. Summary of minor-element analyses of samples from the complex at Democrat Creek and the Gem Park Complex .

8. Abundance of elements in several types of rocks $\ldots \ldots \ldots \ldots \ldots \ldots \ldots$

9. Rubidium and strontium content and several ratios for rocks from the McClure Mountain Complex and the complex

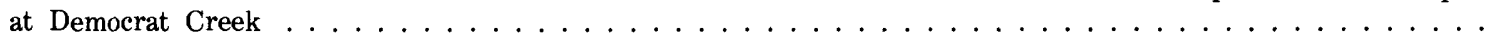

10. Rare-earth element content of rocks from the McClure Mountain Complex and the complex at Democrat Creek . . 


\title{
ALKALINE ROCK COMPLEXES IN THE WET MOUNTAINS AREA, CUSTER AND FREMONT COUNTIES, COLORADO
}

\author{
By Theodore J. Armbrustmacher
}

\begin{abstract}
Three alkaline intrusive complexes of Cambrian age occur in the Wet Mountains area, Colorado. The McClure Mountain Complex consists of mafic-ultramafic cumulates, hornblende-biotite syenites, nepheline syenites, and mafic nepheline-clinopyroxene rocks intruded by carbonatite, several kinds of syenite, and lamprophyre, mainly as dikes, and by thorium-bearing veins. The Gem Park Complex consists chiefly of mafic-ultramafic cumulates intruded by carbonatite, lamprophyre, and nepheline syenite pegmatite. The complex at Democrat Creek contains subordinate amounts of mafic-ultramafic rocks and abundant quartz syenite bordered partly by a zone of brecciation; the complex is intruded by syenite dikes and a quartz-barite-thorite vein.

Contents of major and minor elements, including rare-earth elements, rubidium, strontium, and strontium isotopic ratios, show that these rocks did not form through fractionation of a single magma, but formed as end products of at least three separate magma groups. The mafic-ultramafic rocks in the McClure Mountain and Gem Park Complexes and the hornblende-biotite syenite in the McClure Mountain Complex appear to have been derived from an alkali basalt parent; the nepheline syenite, mafic nepheline-clinopyroxene rock, and carbonatite from the McClure Mountain Complex and the carbonatite from the Gem Park Complex appear to have had a more alkaline parent rock such as nephelinite; and the quartz syenite and mafic-ultramafic rock of the complex at Democrat Creek appear to have evolved from a tholeiitic basalt parent.
\end{abstract}

\section{INTRODUCTION}

Alkaline rocks in the Wet Mountains area of southcentral Colorado, located about $20 \mathrm{~km}$ southwest of Canon City, Colo., about $5 \mathrm{~km}$ south of the Arkansas River, and northeast of the Sangre de Cristo Range and the Wet Mountain Valley, occur in three distinct complexes: the McClure Mountain Complex, the Gem Park Complex, and the complex at Democrat Creek. Additional spatially and presumably genetically related lamprophyre, carbonatite, and red syenite occur mainly as dikes. Quartz-barite-thorite veins also appear to be related to the episode of alkaline magmatism.

The McClure Mountain Complex contains nepheline syenite, hornblende-biotite syenite, mafic nephelineclinopyroxene rocks, and mafic-ultramafic cumulate rocks (Shawe and Parker, 1967). The Gem Park Complex contains mafic-ultramafic rocks nearly identical to those in the McClure Mountain Complex, and a single exposure of nepheline syenite pegmatite (Parker and
Sharp, 1970). The complex at Democrat Creek contains quartz syenite and breccia, and mafic-ultramafic rocks that were mapped by Brock and Singewald (1968) as Precambrian gabbroic gneisses and metamorphosed ultramafic rocks, but that were thought by Heinrich and Dahlem (1966) to be similar to the gabbros and pyroxenites of the Gem Park and McClure Mountain Complexes. The rocks at Democrat Creek are less notable for their similarities to the rocks of the other two complexes than for their differences.

The intrusive complexes and associated dikes are 520 m.y. old according to Olson and others (1977). However, their dating of leucocratic rocks from the McClure Mountain Complex and the complex at Democrat Creek by fission-track, potassium-argon, and rubidium-strontium techniques could not resolve any differences in the ages of the various complexes or in the ages of different syenites at McClure Mountain. Subsequent rubidium and strontium isotopic determinations by C. E. Hedge (Armbrustmacher and Hedge, 1982) yielded ages of $535 \pm 5$ m.y. for syenites at McClure Mountain and $511 \pm 8 \mathrm{~m}$.y. for syenites at Democrat Creek.

The petrology of the Wet Mountains alkaline rocks, as outlined by major- and minor-element contents, suggests the presence of several different rock series. Data on rubidium, strontium, rare-earth elements, and strontium isotopes show that rocks of the complexes did not form through fractionation of a single magma, but formed instead as end products of several magmas generated from different source materials.

\section{AGKNOWLEDGMENTS}

Studies of the Wet Mountains alkaline rocks benefited from discussions with U.S. Geological Survey geologists, especially R. L. Parker, W. N. Sharp, M. R. Brock, and J. C. Olson. Determinations of rubidium and strontium isotopes and rare-earth elements by $\mathrm{C}$. E. Hedge of the U.S. Geological Survey and discussions with Hedge regarding their interpretation resulted in invaluable insight into the petrology of the alkaline complexes. I. K. Brownfield assisted in the field and in the laboratory. 
ALKALINE ROCK COMPLEXES IN THE WET MOUNTAINS AREA, COLORADO

\section{GEOLOGIC SETTING}

The alkaline rocks of the Wet Mountains area intrude Proterozoic X metamorphic rocks-chiefly layered granitic gneisses, hornblende gneisses, and amphibolites-and Precambrian intrusive granitic rocks of Boulder Creek or Proterozoic X age (1,720 m.y.) and Silver Plume or Proterozoic Y age $(1,450$ m.y.) (Taylor and others, 1975a, b). The western edge of the Gem Park Complex is bordered by Tertiary welded tuffs, boulder gravels, and water-laid tuffs (Parker and Sharp, 1970). According to Scott and Taylor (1975), these rocks are correlative with the Oligocene East Gulch, Thorn Ranch, and Gribbles Park Tuffs of the Thirtynine Mile volcanic field.

The host rocks adjacent to the alkaline complexes, carbonatite dikes, and thorium deposits, and parts of the complexes themselves, are typically fenitized (Heinrich and Alexander, 1976). Quartzo-feldspathic host rocks commonly show loss of quartz; their feldspars are replaced by potassic feldspar containing abundant ferric-oxide inclusions, their mafic minerals are destroyed or replaced by blue and green sodic amphiboles and pyroxenes, and their fractures are lined with these minerals or with epidote. Where mafic- ultramafic host rocks are fenitized, the most conspicuous result is the replacement of mafic minerals by vermiculite; in some places the concentrations are nearly high enough to be commercially valuable.

The alkaline complexes, carbonatites, and thorium deposits appear to be bounded by the Ilse fault on the east and the Texas Creek and Westcliffe faults on the west (fig. 1). Relative movement along the Texas Creek fault ('Taylor and others, 1975a) and along the Ilse fault (Scott and others, 1976) is east-side upward; this movement suggests that the alkaline intrusive rocks may occupy a different structural level than do the blocks west of the Texas Creek fault and east of the Ilse fault. To date, rocks related to the alkaline complexes have not been observed in the structural blocks east and west of the one containing the complexes. This structural block is in turn broken by a set of predominantly northwest-striking vertical faults that likely served as conduits for fluids that formed thorium veins, lamprophyres, red syenite dikes, and carbonatites, especially southeast of the alkaline complexes.

\section{MCGLURE MOUNTAIN COMPLEX}

The largest of the three complexes, the McClure Mountain Complex (fig. 2), consists chiefly of a series of mafic-ultramific rocks at Iron Mountain, leucocratic hornblende-biotite syenite and nepheline syenite, mafic nepheline-clinopyroxene rocks, and various dike rocks including carbonatites, lamprophyres, and syenites. Distance across its widest east-west dimension is about $11 \mathrm{~km}$ and across its north-south dimension is $10 \mathrm{~km}$. Exposures of the mafic-ultramafic rocks at Iron Mountain are about $5.8 \mathrm{~km}$ long in a northwest-southeast direction and $2-3.5 \mathrm{~km}$ wide in a northeast-southwest direction.

Apparently, Parker and Hildebrand (1963) first mentioned the McClure Mountain Complex and its alkaline nature. The mafic-ultramafic part of the complex at Iron Mountain has been discussed by Shawe and Parker (1967), who also adopted and defined the McClure Mountain Complex as a formal term. Although the leucocratic part of the complex has been mentioned many times (Shawe and Parker, 1967; Parker and Sharp, 1970; Heinrich and Dahlem, 1966; Heinrich, 1966; Heinrich and Moore, 1970), detailed information on the rocks is sparse. Rock relationships in the complex have been interpreted by Heinrich and Alexander (1979) to represent a "mafic-alkalic ring complex."

The rocks of the McClure Mountain Complex do not appear to have much economic potential. Small-scale production of iron from titaniferous magnetite in the mafic-ultramafic rocks at the Iron Mountain mine occurred as early as 1873 (Becker and others, 1961); however, the high titanium content of the magnetite, as much as 14 percent $\mathrm{TiO}_{2}$, and the low tonnage have hindered further development. Several carbonatite dikes intruding rocks of the complex have been prospected for thorium and rare-earth elements.

\section{MAFIC-ULTRAMAFIC ROCKS}

Mafic and ultramafic rocks of the Iron Mountain part of the McClure Mountain Complex form a funnel-shaped layered series of rocks intruded by small, discordant bodies of similar mafic and ultramafic rocks as well as by dikes of carbonatite and syenite (Shawe and Parker, 1967). Mineral content of rocks in the layered series and in the discordant intrusions is similar. The rocks differ mainly on the basis of texture; rocks in the layered series show stratification, but rocks in the discordant intrusion do not. These two rock types are not distinguished on figure 2, but are shown by Shawe and Parker (1967, pl. 1).

\section{LAYERED SERIES}

The stratified rocks consist of igneous cumulates comprising essentially five cumulus minerals-plagioclase, a calcium-rich clinopyroxene, olivine, magnetite, and spinel-that occur in varying proportions. All these minerals, except spinel, along with reddish-brown amphibole and red biotite are present as intercumulus material; considerable variations in mineral proportions and in grain size can occur within a distance of a few 


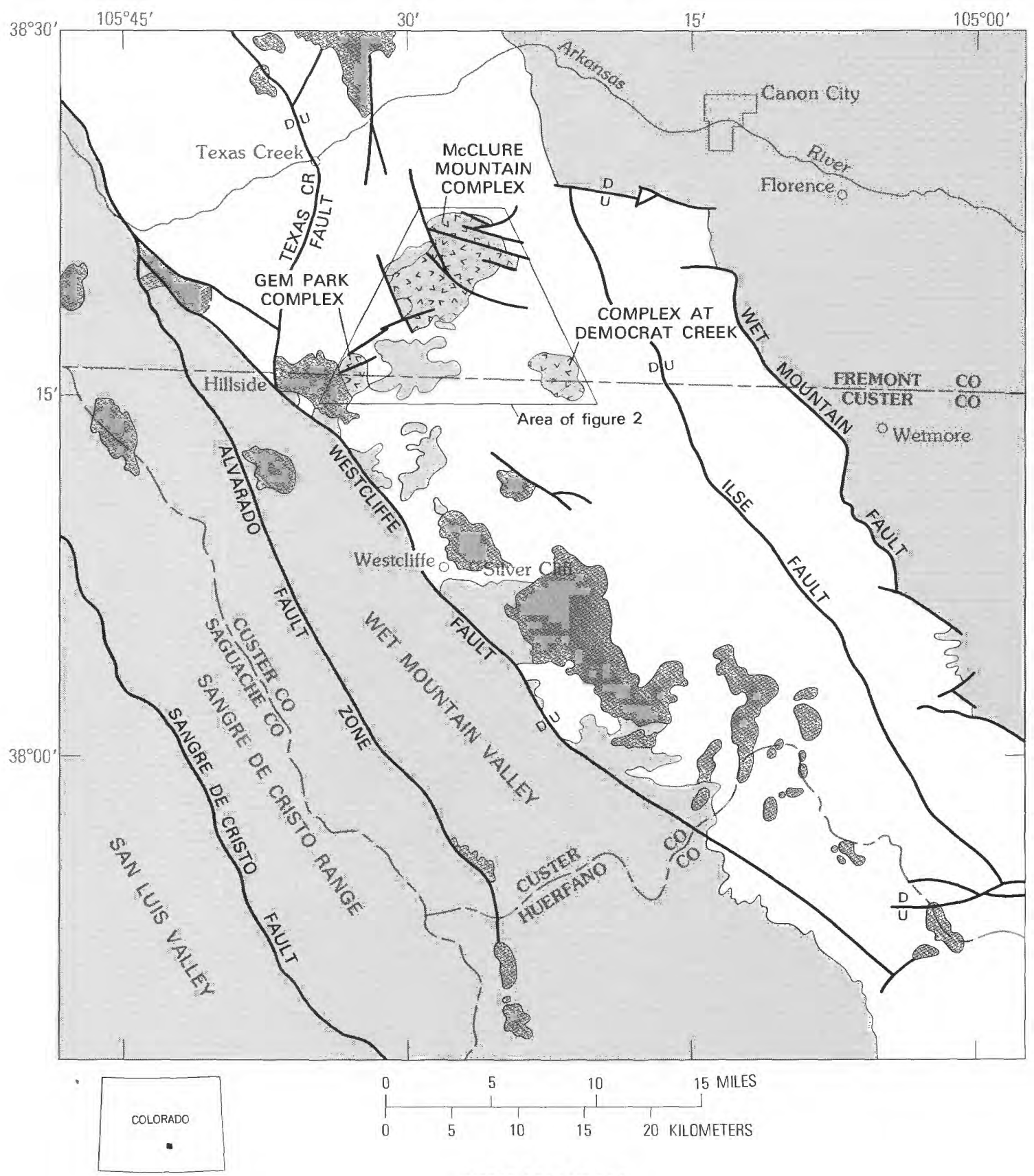

\section{EXPLANATION}

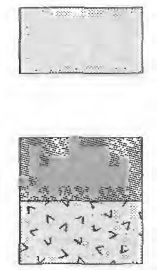

Tertiary, Mesozoic, and Paleozoic sedimentary rocks

recambrian metamorphic and igneous rocks

Tertiary volcanogenic rocks

Cambrian alkaline complexes

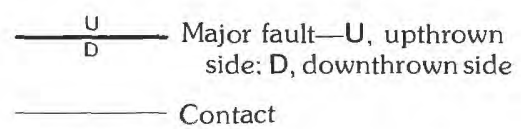

FIGURE 1.-Map of Wet Mountains area showing location of alkaline complexes, Fremont and Custer Counties, Colo. Geology modified from Scott and others (1976).

centimeters. These characteristics are typical of igneous cumulates (Jackson, 1961). Plots of modal plagioclase, clinopyroxene, and olivine for 20 mafic-ultramafic rocks (fig. 3) show the diversity of rock types found. These rock types include clinopyroxene adcumulates, plagioclase adcumulates, and orthocumulates that consist of 


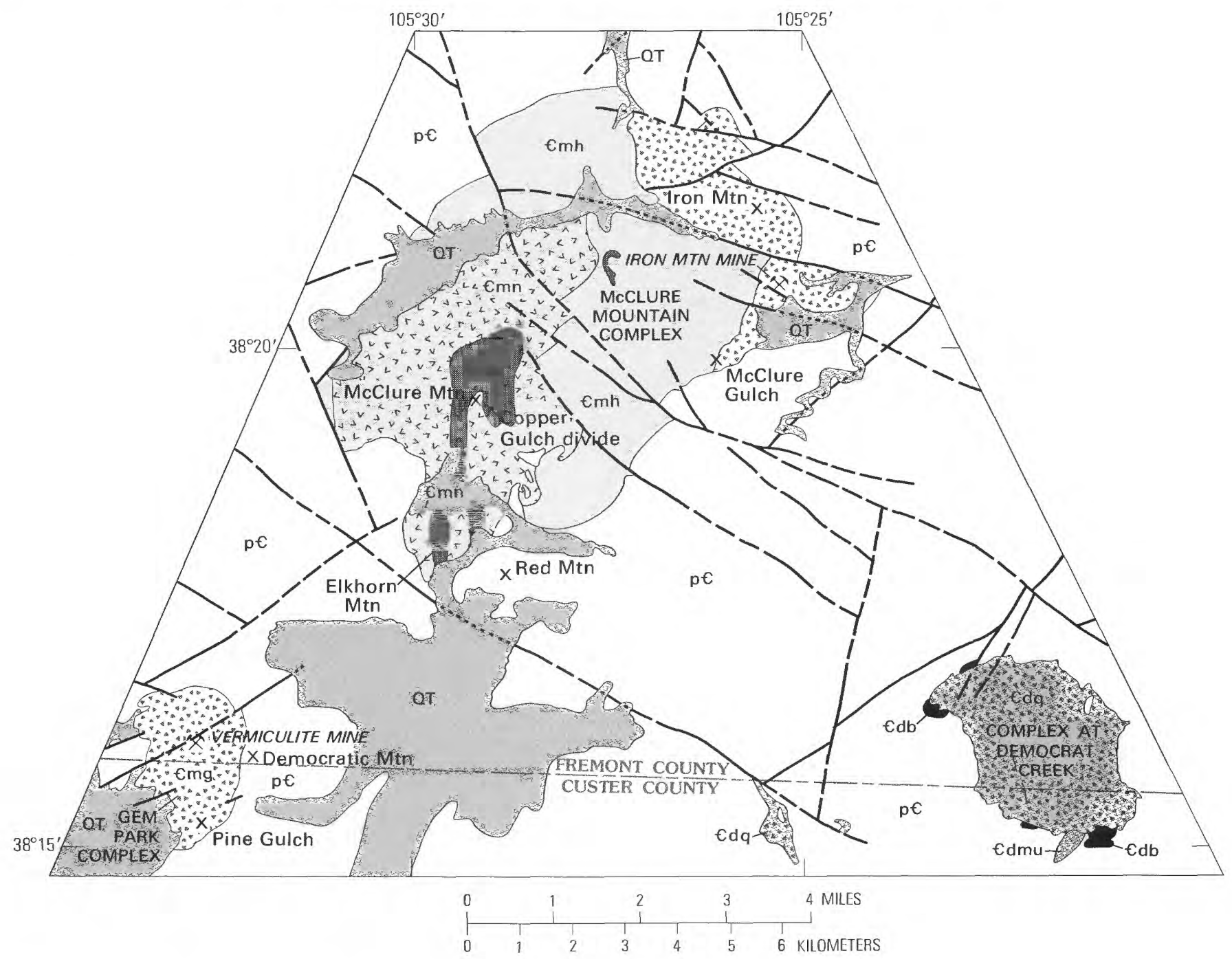

Figure 2.-Alkaline complexes of the Wet Mountains, Fremont and Custer Counties, Colo. Geology modified from Taylor and others (1975a and 1975b) and Olson and others (1977).

the cumulus minerals clinopyroxene, plagioclase, olivine, magnetite, and rarely spinel in various proportions.

Most clinopyroxene appears in thin section as a tanto neutral-colored, unzoned, sometimes pleochroic cumulus mineral - most likely titaniferous augite; rarely does it occur as an intercumulus mineral. In augite-rich rocks, adcumulus growth of the augite is sometimes apparent owing to slight differences in optical orientation of the augite primocryst and the later, interstitial augite (fig. 4). Augite can also exhibit crystallographically controlled, exsolved, opaque iron oxides (fig. 5).

Plagioclase primocrysts commonly exhibit adcumulus growth; triple-point junctions near $120^{\circ}$ are abundant in plagioclase-rich rocks (fig. 6). Most optical measure- ments place the plagioclase in the labradorite range. Clouded plagioclase-plagioclase that contains crystallographically controlled, exsolved iron oxide-occurs in some rocks, especially in those in which the associated augite also contains exsolved iron-oxide inclusions (fig. 7). This exsolution of crystallographically oriented iron oxide is due to subsolidus cooling at rates slow enough to allow exsolution of structural iron (iron in lattice sites; Armbrustmacher and Banks, 1974). Plagioclase is not obviously zoned.

In this study, olivine adcumulates have not been observed and intercumulus olivine is not abundant. The maximum modal olivine content observed thus far is about 58 percent by volume. Some olivine is partly altered to pale yellowish-green serpentine-type minerals 
CORRELATION OF MAP UNITS
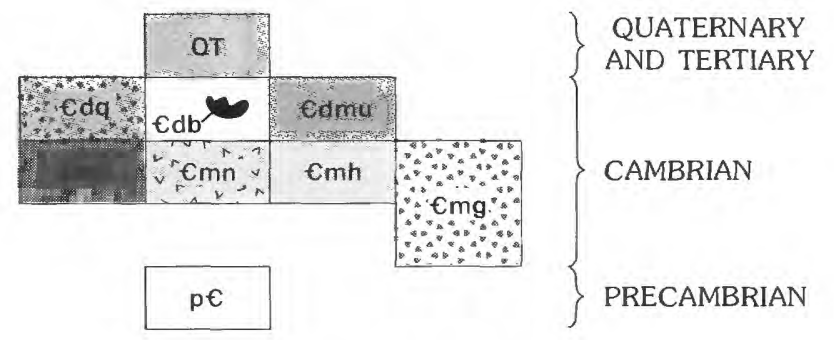

\section{LIST OF MAP UNITS}

\begin{tabular}{|c|c|}
\hline QT & $\begin{array}{l}\text { Quaternary and Tertiary } \\
\text { clastic and volcaniclastic } \\
\text { deposits }\end{array}$ \\
\hline & $\begin{array}{l}\text { Cambrian }(511-535 \text { m.y. } \\
\text {-old rocks) }\end{array}$ \\
\hline Cedge & $\begin{array}{l}\text { Quartz syenite of complex } \\
\text { at Democrat Creek }\end{array}$ \\
\hline$\epsilon \mathrm{db}^{2}$ & $\begin{array}{l}\text { Breccia of complex at } \\
\text { Democrat Creek }\end{array}$ \\
\hline ramu & $\begin{array}{l}\text { Mafic-ultramafic rocks of } \\
\text { complex at Democrat } \\
\text { Creek }\end{array}$ \\
\hline$x_{2}=1$ & $\begin{array}{l}\text { Mafic nepheline-clinopyroxene } \\
\text { rocks of McClure Mountain } \\
\text { Complex }\end{array}$ \\
\hline 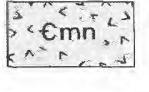 & $\begin{array}{l}\text { Nepheline syenite of McClure } \\
\text { Mountain Complex }\end{array}$ \\
\hline$€ m h$ & $\begin{array}{l}\text { Hornblende-biotite syenite } \\
\text { of McClure Mountain } \\
\text { Complex }\end{array}$ \\
\hline$\therefore \mathrm{Cmg}$ & $\begin{array}{l}\text { Mafic-ultramafic rocks of } \\
\text { Mountain and } \\
\text { Gem Park Complexes }\end{array}$ \\
\hline$p \in$ & $\begin{array}{c}\text { Precambrian metamorphic } \\
\text { and igneous rocks }\end{array}$ \\
\hline & $\begin{array}{l}\text { Fault-Dashed where approximately } \\
\text { located; dotted where concealed }\end{array}$ \\
\hline$x$ & Localities mentioned in text \\
\hline
\end{tabular}

FIGURE 2.-Continued.

and opaque iron oxides. Rocks containing fairly abundant olivine that is partly altered show abundant, closely spaced fractures that connect olivine grains (fig. 8). This feature suggests that the alteration process introduced a volume change and that the resultant stress is relieved by fracturing.

Magnetite occurs both as cumulus and as intercumulus minerals. Exploitation of layers of nearly 98 percent cumulus magnetite occurred at the Iron Moun-

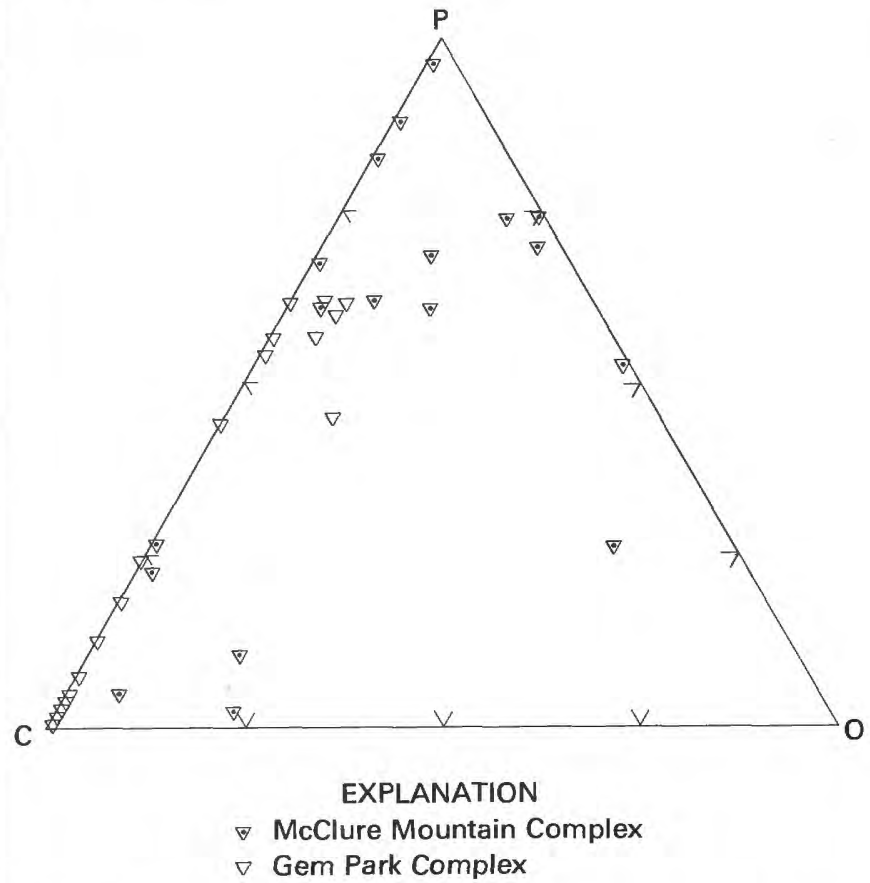

Figure 3.-Modal variation in plagioclase (P), clinopyroxene $(\mathrm{C})$, and olivine $(0)$ of mafic-ultramafic rocks from the McClure Mountain and Gem Park Complexes. Values are in percent by volume.

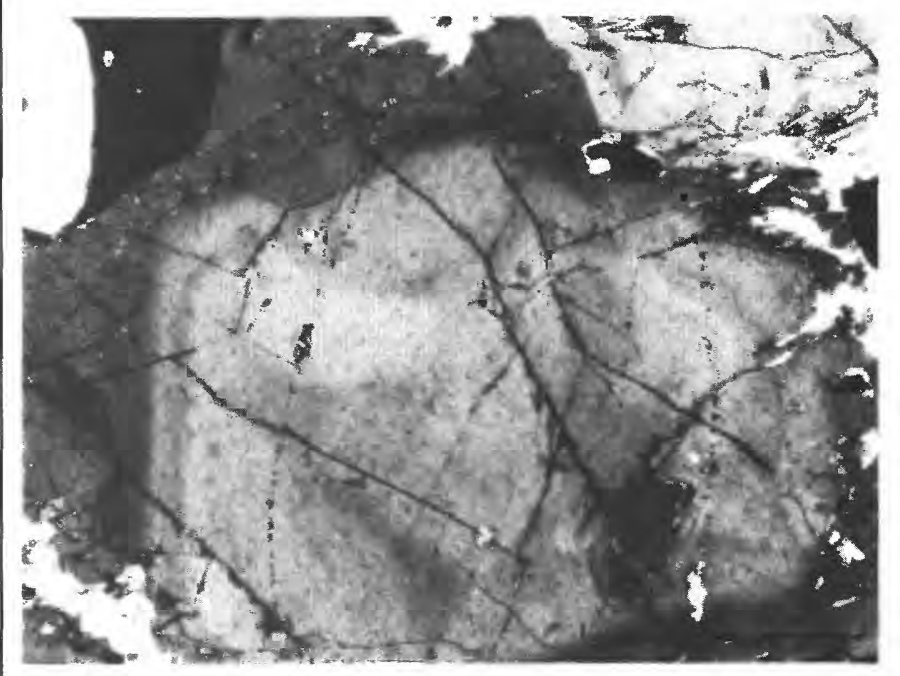

FIGURE 4.-Adcumulus growth of clinopyroxene on clinopyroxene. Sample 359; partly crossed nicols; bar is $0.5 \mathrm{~mm}$.

tain mine. Green spinel is invariably associated with magnetite, and the spinel/magnetite ratio increases as the total magnetite content of a rock increases. Most spinel appears to be associated with cumulus magnetite, and it is rarely associated with intercumulus magnetite.

Strongly pleochroic reddish-brown amphibole, which has a large optic angle, is most similar to kaersutite in optical properties. The amphibole, which may poikilitically enclose cumulus augite and magnetite, appears to have formed from intercumulus fluids. Some 


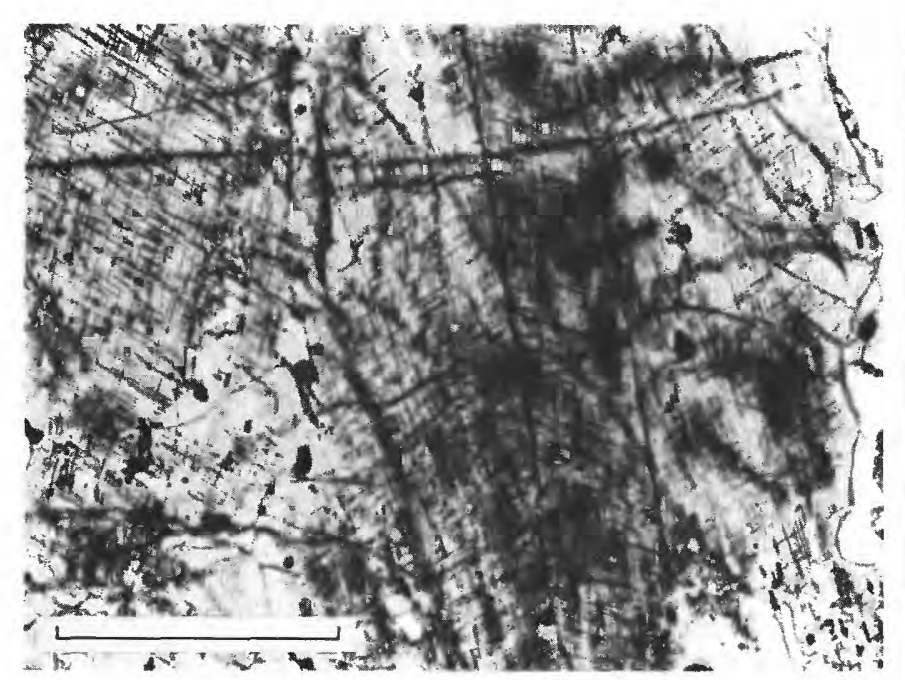

Figure 5.-Crystallographically oriented iron oxide exsolving from clinopyroxene. Sample 392; plane light; bar is $0.5 \mathrm{~mm}$.

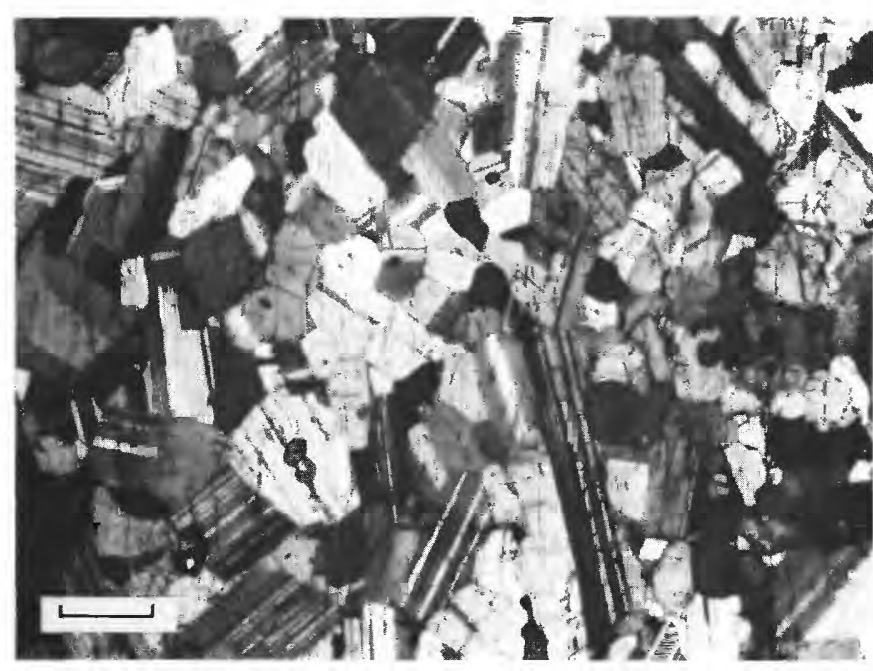

Figure 6.-Anorthositic rock with abundant triple-point grain boundaries meeting at $120^{\circ}$. Sample 457 ; partly crossed nicols; bar is $0.5 \mathrm{~mm}$.

of the amphibole also forms reaction rims around both augite and magnetite. Sparse green amphibole appears to be a product of the alteration of clinopyroxene.

Most strongly pleochroic biotite, red to neutral, is associated with magnetite. A few rocks contain euhedral apatite, which appears to have coprecipitated with magnetite.

The presence of both a single calcium-rich clinopyroxene, as opposed to two pyroxenes, and a sodic amphibole verifies the alkaline nature of these mafic-ultramafic rocks.

\section{DISCORDANT INTRUSIONS}

Field evidence for recognizing the ultramafic discordant intrusions include their discordant nature, the

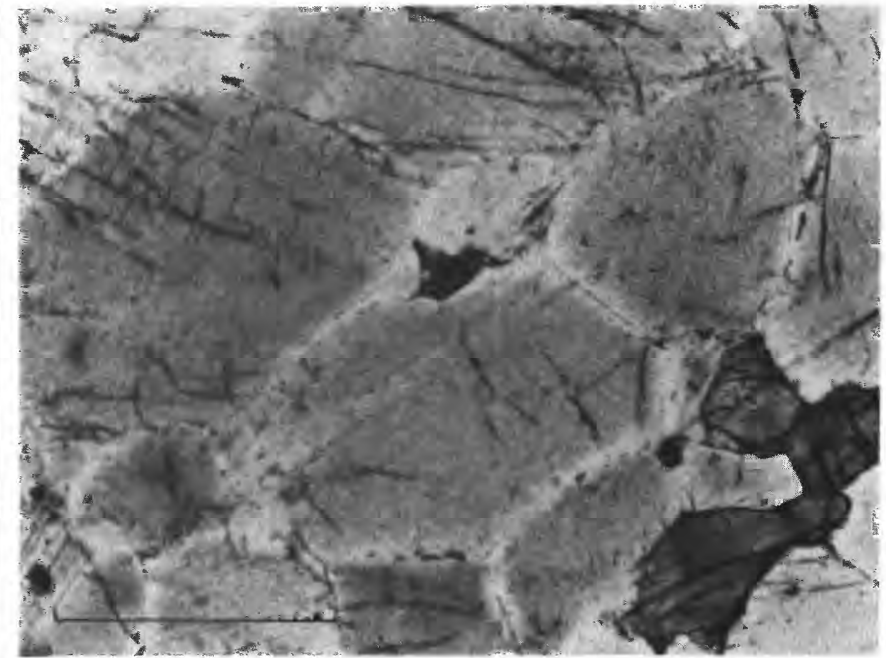

Figure 7.-Plagioclase with exsolved iron oxide. Sample number 402Z; plane light; bar is $0.5 \mathrm{~mm}$.

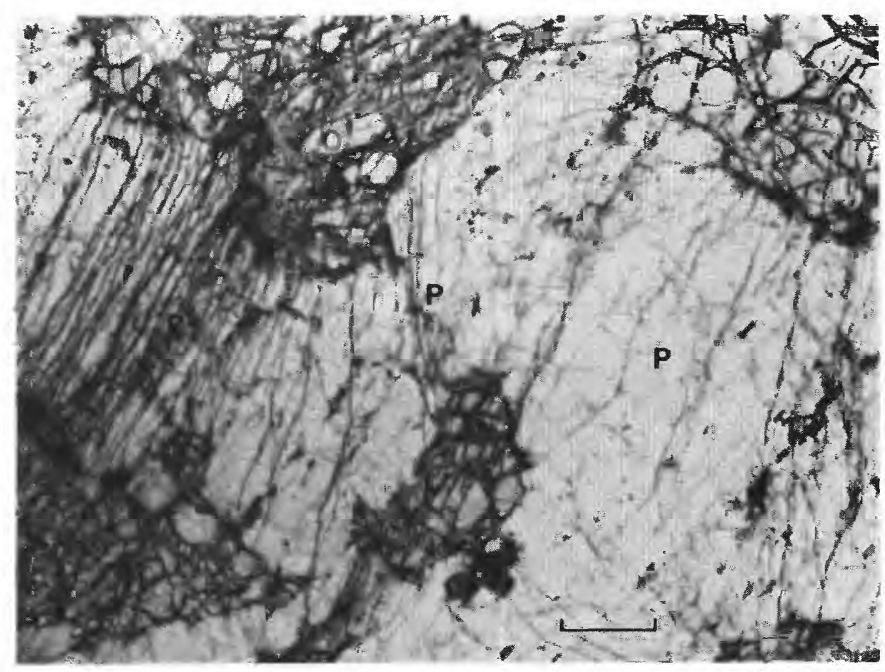

Figure 8.-Closely spaced fractures in plagioclase (P) connecting olivine grains $(O)$. Sample 396; plane light; bar is $0.5 \mathrm{~mm}$.

xenoliths of rocks of the layered complex near contacts, and the lack of layering (Shawe and Parker, 1967). Rocks of the discordant intrusions consist of minerals that commonly are identical to those in rocks of the layered intrusions. In thin section, these rocks tend to be equigranular, and the distribution of various minerals tends to be more homogeneous than that in the layered rocks.

\section{LEUCOCRATIC ROCKS}

Two distinct, mappable types of leucocratic rocks, hornblende-biotite syenite and younger nepheline syenite, occur in the McClure Mountain Complex; neither contains modal or normative quartz. These rocks intrude the mafic-ultramafic rocks at Iron Mountain and 
are in turn intruded by red syenite dikes, carbonatite dikes, and lamprophyre dikes. The nepheline syenite intrudes the hornblende-biotite syenite. Precambrian host rocks adjacent to syenite contacts are fenitized to varying degrees; one of the best examples is at Red Mountain (fig. 2), just south of the McClure Mountain Complex. Fenitization of mafic-ultramafic rocks at Iron Mountain adjacent to the syenites is generally not apparent, probably because of structural complicationsmuch of that contact is a fault contact. However, at McClure Gulch, the mafic-ultramafic rocks are cut by nepheline syenite dikes (fig. 9). The syenites are fenitized along narrow zones adjacent to later dikes of carbonatite and red syenite. The development of ferricoxide-bearing potassic feldspars has turned the lightgray syenite host rock to pink; the original mafic minerals tend to be destroyed or replaced by a vermiculitelike mica. Breccia zones have not been observed in the vicinity of rocks of the McClure Mountain Complex, although breccia pipes at nearby Piñon Peak, $5.5 \mathrm{~km}$ north of the complex (Taylor and others, 1975b), have been related to the episode of development of alkaline rocks at McClure Mountain by Heinrich and Dahlem (1967).

\section{NEPHELINE SYENITE}

Nepheline syenite in the McClure Mountain Complex is centrally located relative to the hornblende-biotite syenite, but is peripheral to the mafic nephelineclinopyroxene rocks (fig. 2). According to Heinrich and Alexander (1979), the nepheline syenite occurs as a stock that intrudes the central core of an alkaline ring complex.

Outcrops of nepheline syenite vary considerably in lithologic details (fig. 10). Outcrop colors range from

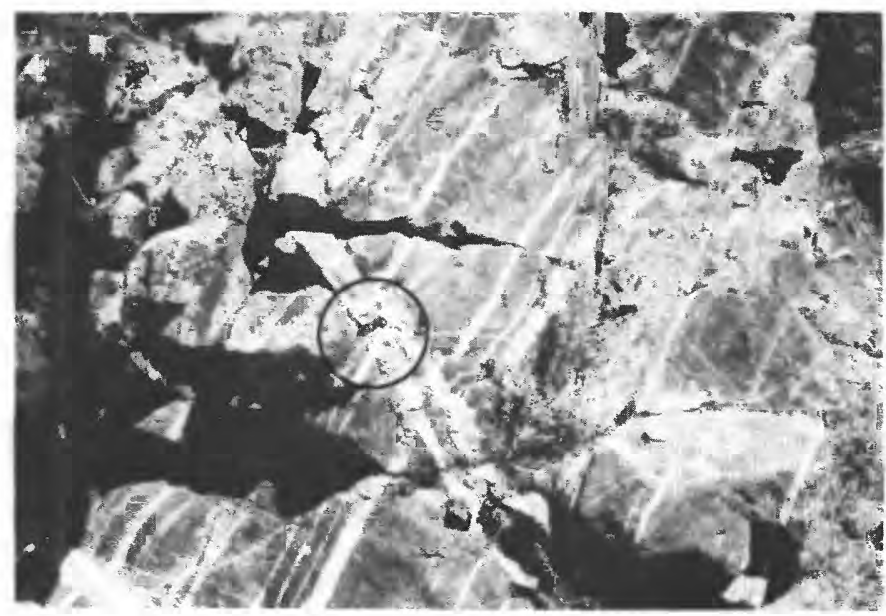

Figure 9.-Outcrop of mafic-ultramafic rocks cut by nepheline syenite dikes (light-colored). This location is along McClure Gulch near contact of mafic-ultramafic rocks and hornblende-biotite syenite. Hammer within circle is $31 \mathrm{~cm}$ long. medium bluish gray to light gray, and grain sizes range from medium to coarse. The medium-grained rocks tend to form sharp, angular outcrops, whereas the very coarse grained rocks form rounded outcrops because of exfoliation, and weather more readily to grus. At a few localities, the coarse-grained rocks are foliated; these rocks have some of the characteristics of cumulus rocks, such as abrupt changes in grain size and mineral proportions. At some localities, the nepheline syenites contain abundant xenoliths, most of which are rounded to subangular fragments of medium- to dark gray nepheline- and sodic pyroxene-rich rocks (fig. 11).

Petrographic examination of nepheline syenite shows several textural types, including hypidiomorphic-granular, allotriomorphic-granular, and porphyritic. In hypidiomorphic-granular rocks, the sodic amphiboles are typically euhedral; as the amphiboles become anhedràl, the texture becomes allotriomorphic-granular. In

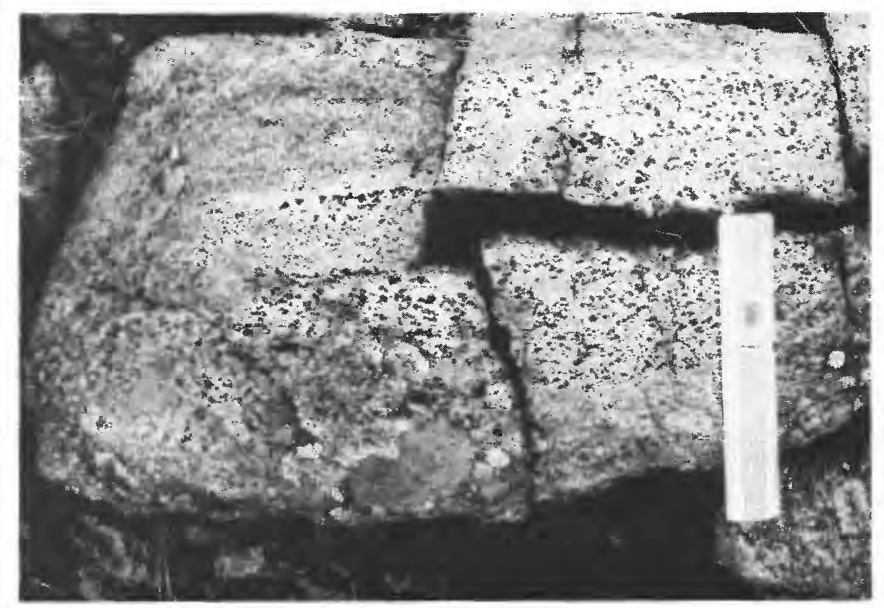

FIGURE 10.-Outcrop of nepheline syenite showing heterogeneous nature of grain size and heterogeneous distribution of minerals. Scale is $17.5 \mathrm{~cm}$ long.

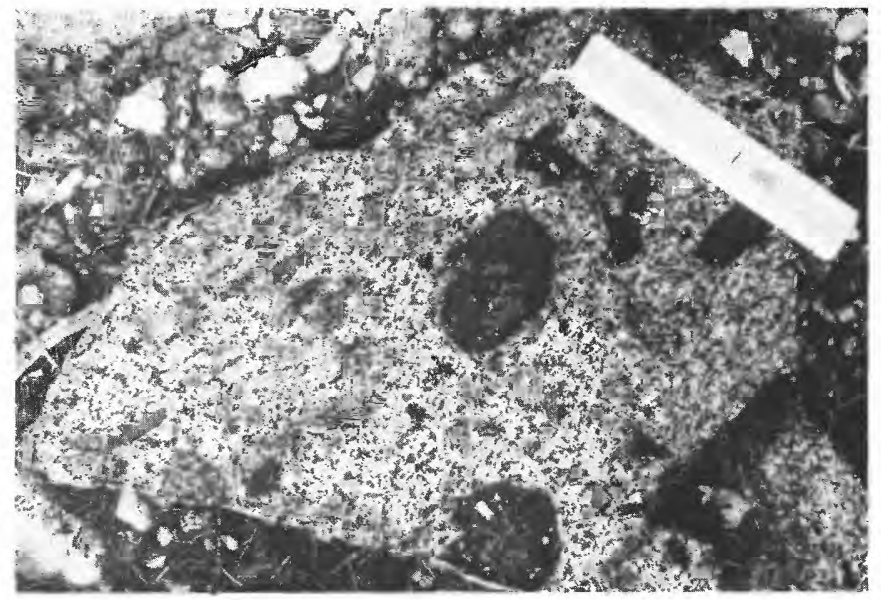

Figure 11.-Xenoliths contained in nepheline syenite. Scale is 17.5 cm long. 
the porphyritic rocks, phenocrysts are nepheline, microperthite, and sodic amphibole in various combinations. In one glomero-porphyritic rock with euhedral nepheline phenocrysts, synneusis structures and groundmass lath-shaped microperthites that swirl around phenocrysts (trachytic texture) give evidence of magmatic turbulence.

The major components of nepheline syenites are microperthite, nepheline, and sodic amphibole, although plagioclase and potassic feldspar are abundant in some samples. The major components also vary widely between samples: microperthite ranges between 0 and 84 percent by volume, nepheline ranges between 0.2 and 38 percent, and sodic amphibole ranges between 0 and 26 percent. The inverse relationship of the abundance of potassic feldspar to the abundance of microperthite suggests that the potassic feldspar may be cryptoperthitic. Sodic pyroxene, which optically best fits aegirine-augite, commonly shows a reaction relationship with sodic amphibole, which optically best fits eckermannite-arfvedsonite (fig. 12). However, sodic pyroxene also occurs independent of the sodic amphibole, commonly in the more nepheline-rich samples. Brown to yellow-brown biotite occurs in nearly every sample in amounts as much as about 10 percent by volume, but averages about 2.5 percent; biotite occurs alone or clotted together with sodic amphibole and magnetite. Sphene, apatite, and magnetite generally are ubiquitous, but rarely exceed about 2.5 percent by volume; they occur separately or clotted together with mafic minerals. Apatite may also form poikilitic inclusions in sodic amphibole. Carbonate minerals, muscovite, and an unidentified isotropic mineral associated with nepheline are all present in small amounts and appear to have a secondary origin. A few samples contain myrmekitic intergrowths of light-green clinopyroxene and nepheline (fig. 13). At Copper Gulch divide (fig. 2), a sodalite-bearing variety of nepheline syenite occurs.

Modal components of the nepheline syenites have been plotted on a QAPF (quartz-alkali feldspar-plagioclase-feldspathoid) diagram (fig. 14). Most of the samples plot in the alkali syenite and foyaite fields, reflecting their typically low plagioclase content. Those samples containing greater amounts of plagioclase plot in the plagifoyaite, essexite, and diorite gabbro fields. Modal nepheline-potassic feldspar-mafic minerals of the same rocks (fig. 15) fall chiefly in the nepheline syenite and adjoining fields. Variation in nepheline/potassic feldspar ratios appears to be considerably greater than variation in mafic-mineral abundance.

\section{HORNBLENDE-BIOTITE SYENITE}

The hornblende-biotite syenite crops out mainly in the northern and eastern parts of the McClure Moun-

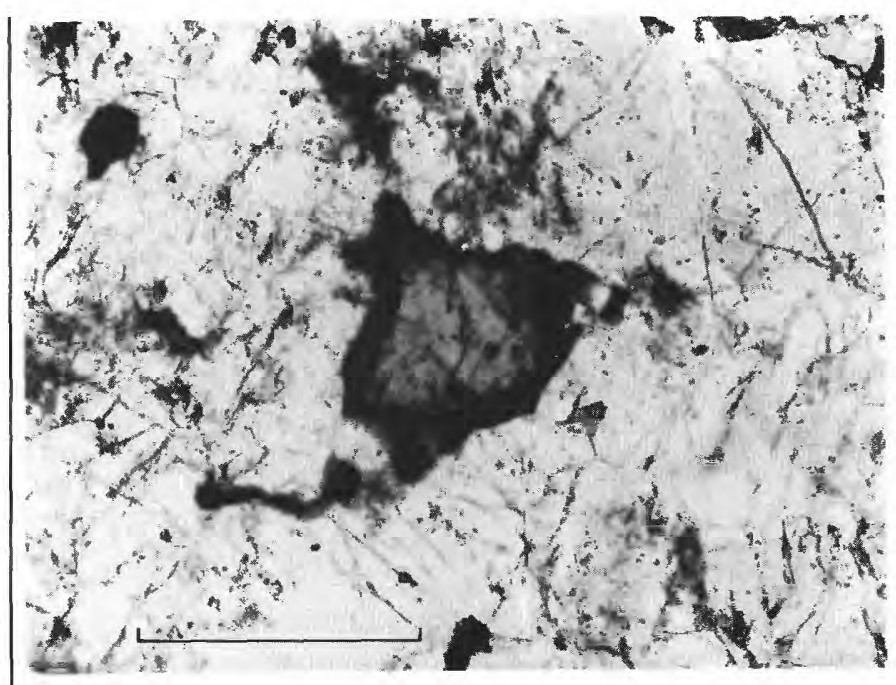

FIGURE 12.-Aegirine-augite rimmed by sodic amphibole in nepheline syenite. Sample $394 \mathrm{X}$; plane light; bar is $0.5 \mathrm{~mm}$.

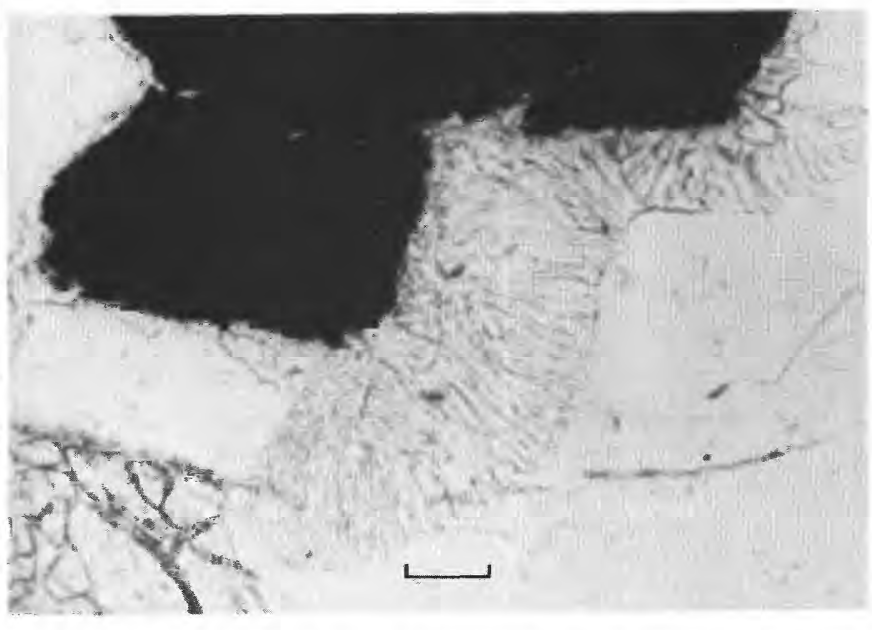

Figure 13.-Myrmekitic intergrowth of clinopyroxene and nepheline in nepheline syenite. Sample WM-62-73; plane light; bar is $0.5 \mathrm{~mm}$.

tain Complex. In addition, the occurrence of hornblende-biotite syenite at the west side of the complex suggests that the syenite forms a nearly circular outerop pattern that surrounds nepheline syenite (fig. 2).

In the field, the hornblende-biotite syenite is considerably more homogeneous at the outcrop scale than nepheline syenite (fig. 16). As discussed later, this homogeneous aspect is characteristic of this rock.

Outcrop colors are predominantly light gray and tan, although some pink varieties also occur. Almost all the rocks are coarse grained, and the outcrops weather to rounded boulders that yield abundant grus. The hornblende-biotite syenite tends to cause rolling meadowland if the land is not dissected locally by streams. 


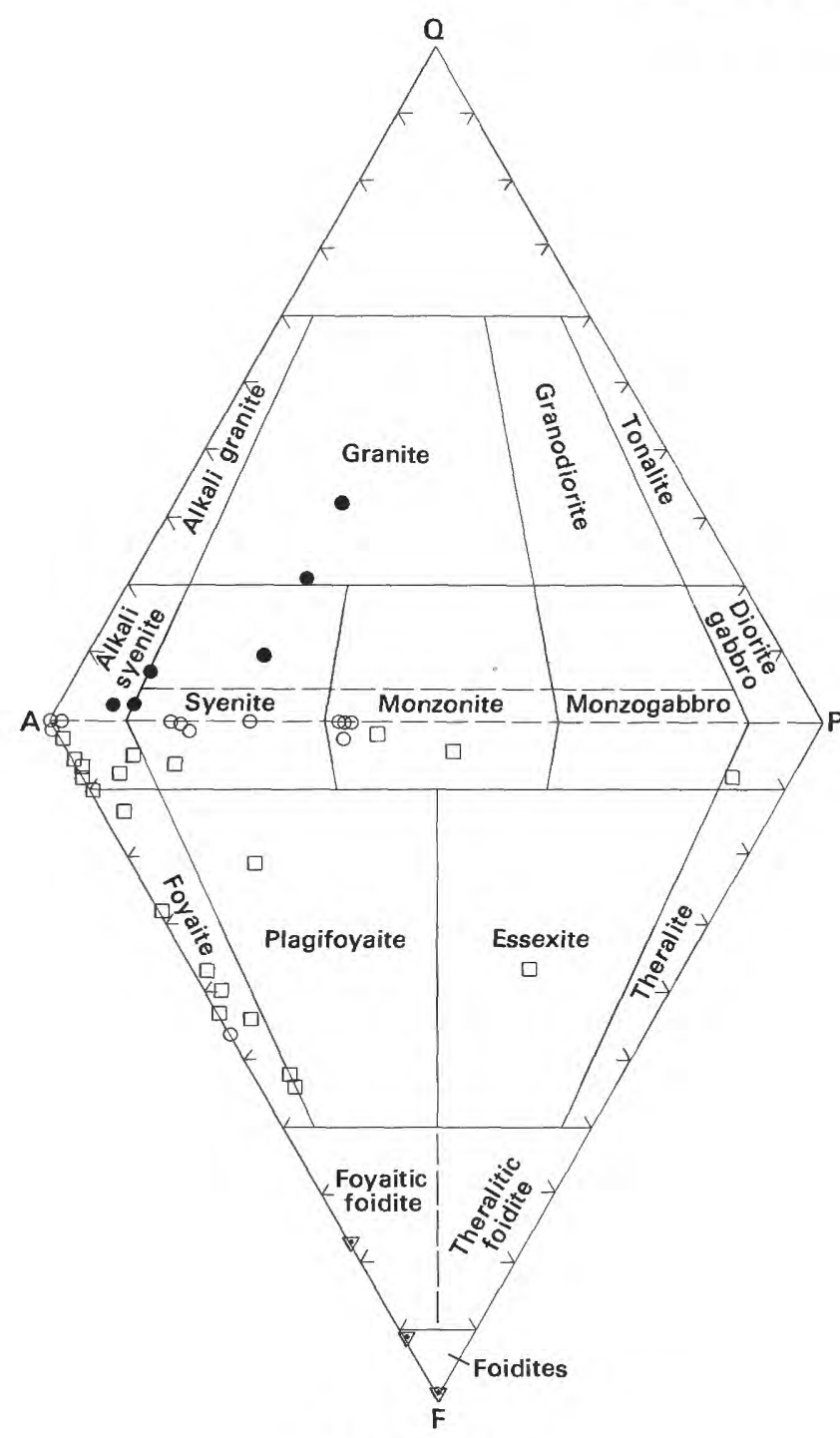

EXPLANATION

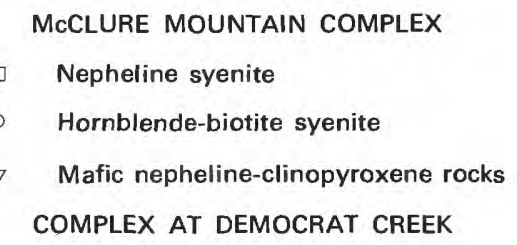

- Quartz syenite

Figure 14.-Modal variation in quartz $(\mathrm{Q})$, alkali feldspar and plagioclase $\left(A n_{0-5}\right)(A)$, plagioclase $\left(A n_{>5}\right)(P)$, and feldspathoid (F) of syenites and mafic nepheline-clinopyroxene rocks from the McClure Mountain Complex and quartz syenites from the complex at Democrat Creek (modified from Sorensen, 1974a, p. 16). Values are in percent by volume.

Petrographic examination shows that the texture of most homblende-biotite syenite is allotriomorphicgranular. Grain sizes range from medium (1-5 mm) to coarse $(>5 \mathrm{~mm})$. A few samples collected in the vicinity of contacts are porphyritic, and the phenocrysts form

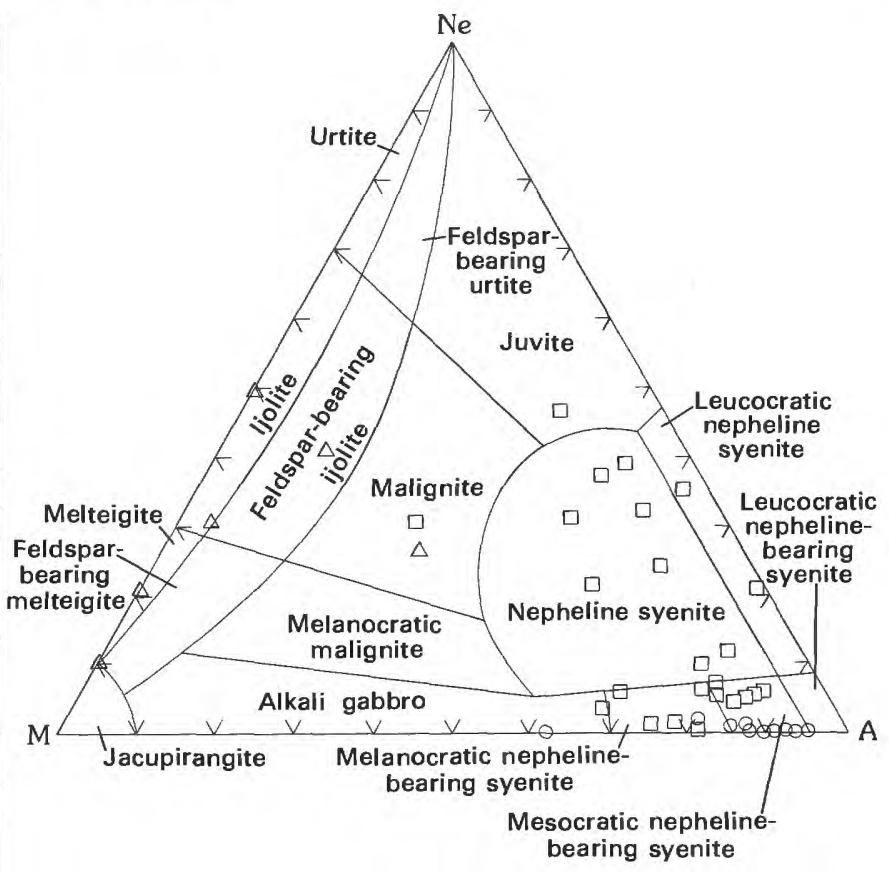

EXPLANATION

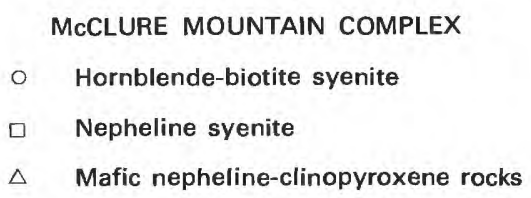

FIGURE 15.-Modal variation in nepheline (Ne), mafic minerals (M), and potassic feldspar (A) of rocks from the McClure Mountain Complex (from Sorensen, 1974a, p. 17). Values are in percent by volume.

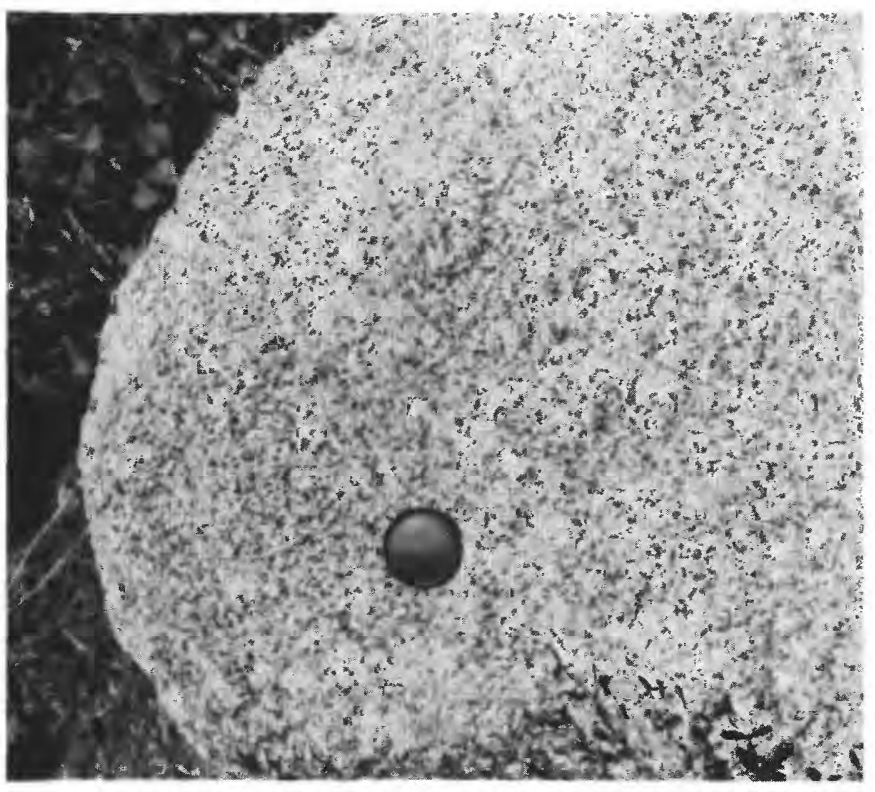

FigURE 16.-Outcrop of homogeneous hornblende-biotite syenite. Lens cover is $6 \mathrm{~cm}$ in diameter. 
medium-grained microperthite. The allotriomorphicgranular rocks consist of medium- to coarse-grained, anhedral, lath-shaped, Carlsbad-twinned microperthite with roughly random orientation. Microperthite ranges from 48 to 93 percent by volume. Some samples contain abundant sodic plagioclase, as much as about 34 percent, but other samples contain no apparent plagioclase except that in microperthite. The mafic minerals and accessory minerals commonly occur together in clots, and these clots may be $10-15 \mathrm{~mm}$ across. Clinopyroxene rarely exceeds 1 percent by volume; it nearly always shows a reaction relationship with sodic amphibole, which ranges from 0.3 to 11 percent, and occurs mainly as remanent cores within the pleochroic, dark-greenishbrown sodic amphibole (fig. 17). Magnetite in some rocks is rimmed by sphene, but euhedral sphene independent of magnetite also is a common constituent. Magnetite, apatite, and sphene, which typically occur in amounts near 2-3 percent, are ubiquitous; muscovite and carbonate appear to be secondary minerals.

Modal components of the hornblende-biotite syenite on a QAPF diagram (fig. 14) plot in alkali syenite, syenite, and monzonite fields primarily because of variations in the microperthite/plagioclase ratio. Modal components of the nepheline-potassic feldspar-mafic minerals (fig. 15) show that the nepheline-bearing samples plot in the melanocratic and mesocratic nepheline-bearing syenite fields.

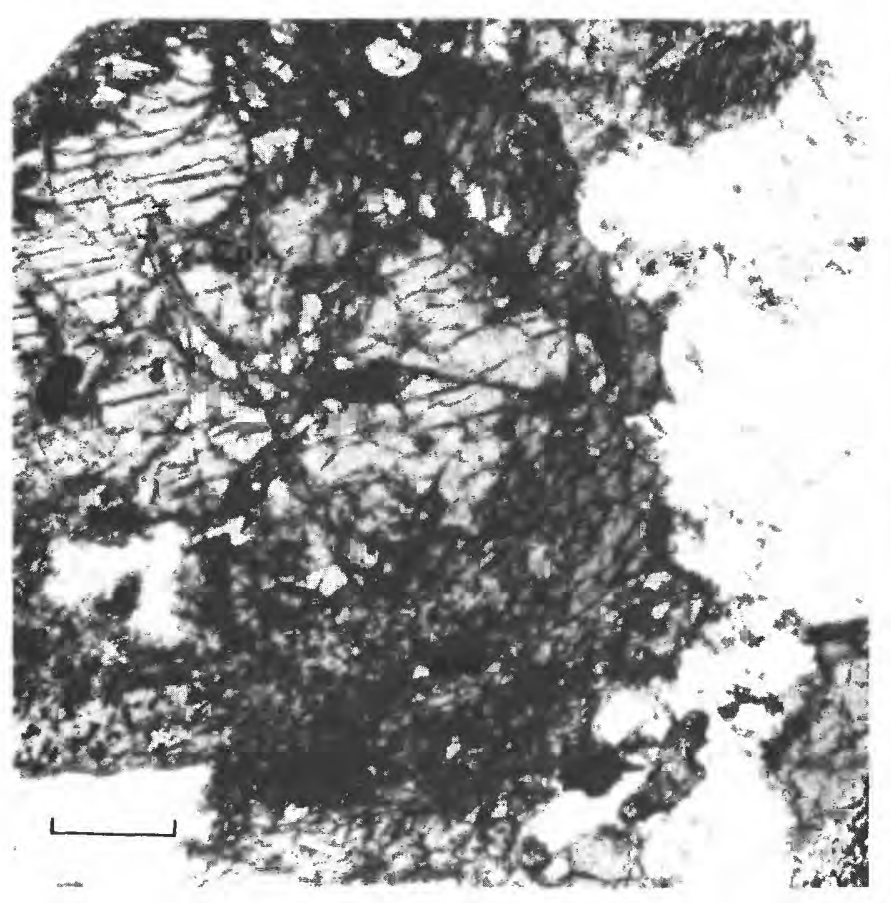

FIGURE 17.-Alteration of clinopyroxene (Cpx) to green amphibole (Am) in hornblende-biotite syenite. Sample 387BX; plane light; bar is $0.5 \mathrm{~mm}$.

\section{MAFIC NEPHELINE-CLINOPYROXENE ROCKS}

Mafic nepheline-clinopyroxene rocks, termed "ijolite" by Heinrich (1966), intrude nepheline syenites in the southern part of the McClure Mountain Complex. Outcrops are dark greenish gray in the field and are texturally inhomogeneous. One outcrop found on the southwest side of Elkhorn Mountain (fig. 2) has a mottled texture owing to large poikilitic grains of nepheline (fig. 18). These rocks weather rather readily and yield a dark-gray soil mantle.

Petrographic studies show at least two textural types, allotriomorphic-granular and poikilitic, and most minerals are medium grained. In the poikilitic type, large grains of nepheline, with or without potassic feldspar, engulf subhedral sodic clinopyroxenes and amphiboles (fig. 19). Nepheline and sodic clinopyroxene, a pale-green aegirine-augite, are the most abundant components. Nepheline ranges from 10 to about 45 percent by volume, and sodic clinopyroxene ranges chiefly between about 30 and 40 percent. One sample containing nearly 30 percent microperthite, the only sample that has identifiable microperthite, contains only 8.4 percent sodic clinopyroxene. Biotite is present in variable amounts, 5-50 percent, and is thus a major component in some samples. Potassic feldspar and sodic amphibole are present in some samples, whereas sphene, magnetite, and apatite are present in all samples examined.

Plots of modal components of mafic nephelineclinopyroxene rocks on a QAPF diagram (fig. 14) are not too informative because of the lack of plagioclase

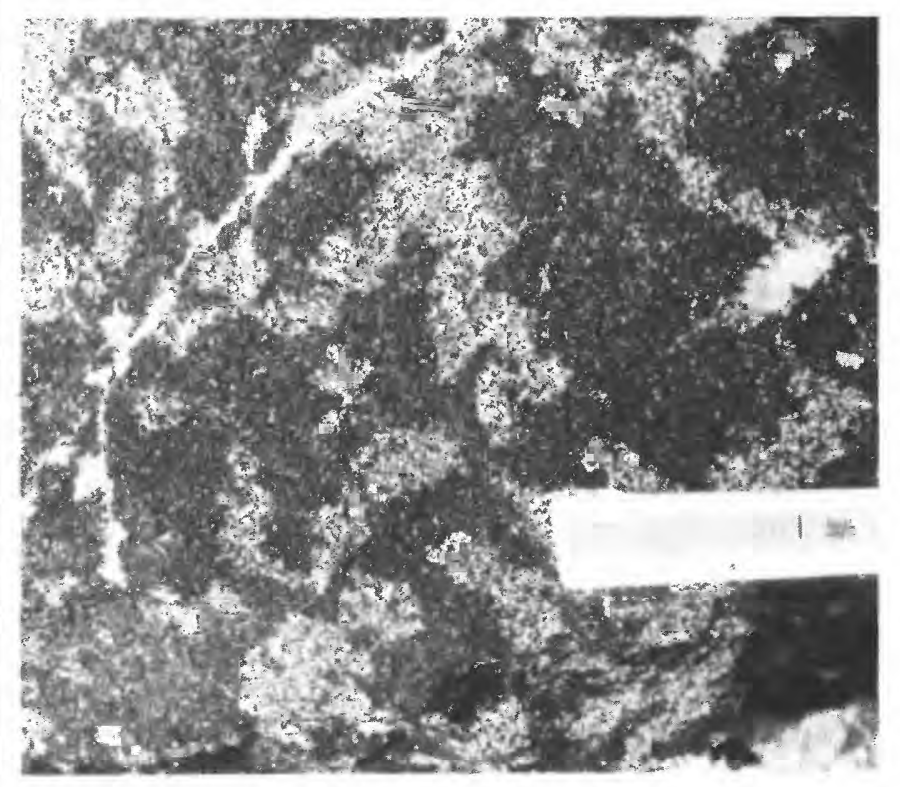

FigURE 18.-Outcrop of mottled mafic nepheline-clinopyroxene rocks. Approximately $12 \mathrm{~cm}$ of scale is shown. 


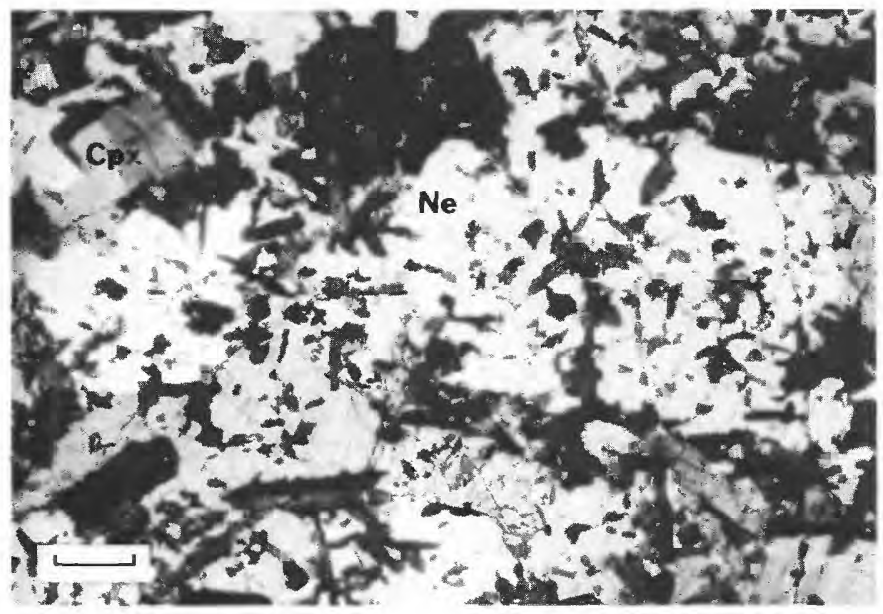

FiguRE 19.- Sodic clinopyroxene (Cpx) and nepheline (Ne) in poikilitic mafic nepheline-clinopyroxene rock. Sample 415X; partly crossed nicols; bar is $0.5 \mathrm{~mm}$.

in these rocks. The plots show only the variation in the sodic feldspar/nepheline ratio, which ranges from 1:1 to 0:1. Plots of modal nepheline-potassic feldsparmafic minerals (fig. 15) show the paucity of potassic feldspar and the greater abundance of mafic minerals relative to the nepheline syenites. Most of the rocks plot in or near the ijolite and feldspar-bearing ijolite fields.

\section{GEM PARK COMPLEX}

The oval-shaped Gem Park Complex is a maximum of about $2.9 \mathrm{~km}$ along a north-south axis and $2.0 \mathrm{~km}$ along an east-west axis (fig.2). The first indication that the rocks at Gem Park were part of an alkaline complex was given by Parker and others (1962); the Gem Park Complex was later adopted as a formal term and described in detail by Parker and Sharp (1970). Various mineral commodities, including nickel, silver, vermiculite, niobium, magnetite, and ornamental stone, have been sought at Gem Park in or adjacent to the complex. Recently, diamond drilling has blocked out an area containing economically interesting amounts of $\mathrm{Nb}_{2} \mathrm{O}_{5}$ in stockwork carbonatite that intrudes rocks of the complex (D. W. Fieldman, oral commun., 1978).

At Gem Park, the mafic-ultramafic rocks weather at a rate greater than that of the surrounding Precambrian granitic gneisses. As a result, rocks tend to be, at best, only moderately well exposed, and are mainly restricted to low, rubbly outcrops. The stratiform nature of the complex is well exhibited in a small shaft just west of the center of the complex (fig. 20) by compositional layering exposed adjacent to a road along Pine Gulch at the south end of the complex, and by layering in core drilled by several companies. The mineral layer-

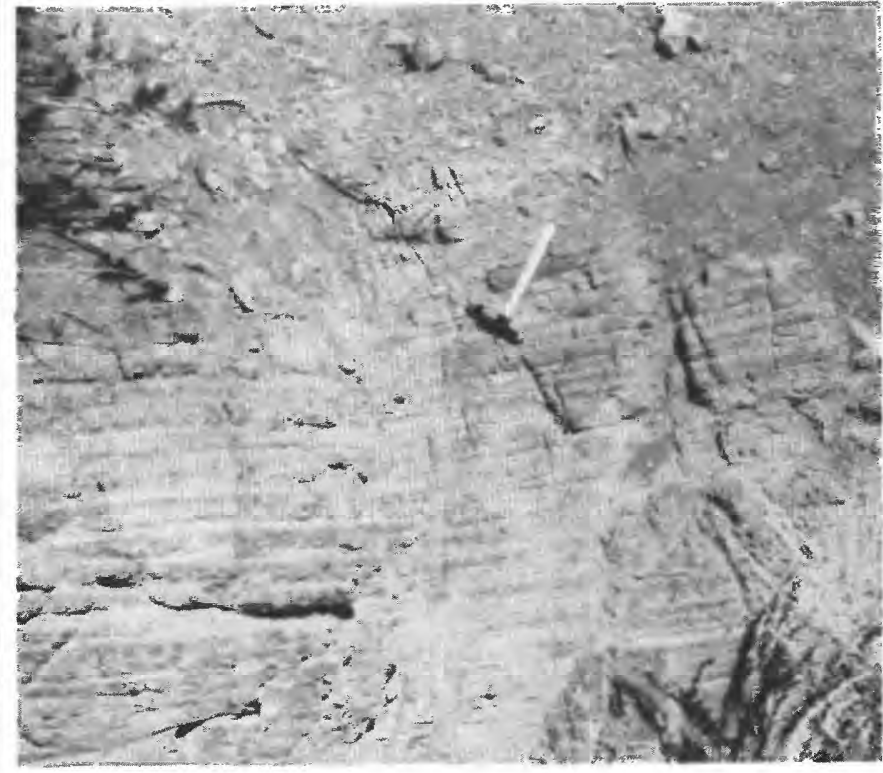

Figure 20.-Cumulus layering in stratiform mafic-ultramafic rocks of the Gem Park Complex. Hammer is $31 \mathrm{~cm}$ long.

ing in the mafic-ultramic rocks dipping consistently toward the center of the complex suggests that the Gem Park Complex may be a funnel-shaped intrusion similar in gross shape to the mafic- ultramafic body at Iron Mountain in the McClure Mountain Complex. The Gem Park Complex is cut by several high-angle normal faults that also cut the volcanic rocks immediately to the west of the complex, the age of the faults is post-Oligocene (Parker and Sharp, 1970).

At least two general types of fenitization occur in the Gem Park Complex: fenitization of enclosing Precambrian granitic gneisses because of metasomatic alteration accompanying intrusion of the rocks of the complex, and fenitization of rocks of the complex because of metasomatic alteration accompanying intrusion of later rocks, mainly carbonatites. An example of the first type of alteration occurs on Democratic Mountain just east of the complex, where Precambrian granitic rock has been fenitized to a pink granitic rock with abundant green, fracture-controlled epidote. This rock has been quarried as an ornamental building stone. An example of the second type of alteration occurs in the north-central part of Gem Park at the Vermiculite mine, where mafic-ultramafic rocks have been metasomatized to an assemblage of aegirine, tremolite-actinolite, augite, phlogopite, vermiculite, dolomite, calcite, barite, apatite, magnetite, and fibrous, blue, sodic amphibole (Parker and Sharp, 1970, p. 10). The source of these fenitizing solutions has been postulated by Parker and Sharp (1970, p. 23) to be a buried central carbonatite core. However, Rock (1976) suggested an incompatibility between calcic plagioclase and carbonatite in alkaline 
complexes. This incompatibility would preclude the possibility of a central carbonatite core, but would not explain the occurrence of carbonatite in a calcic plagioclase-rich alkaline-rock complex.

\section{MAFIC-ULTRAMAFIC ROCKS}

The mafic-ultramafic rocks in the Gem Park Complex, which are predominantly igneous cumulates, comprise the cumulus minerals plagioclase, clinopyroxene, olivine, and magnetite. The most abundant rock types are plagioclase-clinopyroxene orthocumulates-the gabbro of Parker and Sharp (1970)-and clinopyroxene adcumulates-the pyroxenite of Parker and Sharp (1970). Locally, plagioclase adcumulates and magnetite orthocumulates are also found. Plagioclase, clinopyroxene, and magnetite also form intercumulus material along with reddish-brown sodic amphibole and red biotite. Modal variation in plagioclase, clinopyroxene, and olivine is shown in the ternary diagram in figure 3 . The most obvious characteristic of mafic-ultramafic rocks in the Gem Park Complex, as compared with the McClure Mountain Complex, is the low amounts of olivine. Parker and Sharp (1970, table 2) reported as much as 6 percent olivine by volume in several samples of gabbro, whereas the current study shows 1 percent or less olivine in any given rock. In thin section, the cumulus minerals clinopyroxene, plagioclase, and olivine appear identical to the minerals in the mafic-ultramafic rocks in the McClure Mountain Complex at Iron Mountain. Pleochroic reddish-brown sodic amphibole, whose optical properties best fit kaersutite, occurs as intercumulus material and appears to have a reaction relationship with magnetite. Pleochroic green amphibole also appears to be an alteration product of kaersutite and clinopyroxene; it occurs in amounts of less than 2 percent by volume. Biotite, pleochroic neutral to red, does not exceed 1.5 percent by volume and is chiefly associated with magnetite. Apatite containing clusters of small two-phase fluid inclusions is also intercumulus and is typically anhedral. Sphene has been identified in only a few rocks.

Drill core from the northern part of the Gem Park Complex has intersections of coarse-grained clinopyroxene adcumulates that contain abundant epigenetic sulfide minerals. These minerals include pyrite, pyrrhotite, and chalcopyrite.

Most of the layered mafic-ultramafic rocks in the Gem Park Complex are similar to the layered mafic-ultramafic rocksat Iron Mountain in the McClure Mountain Complex. Because of these similarites, the cumulus rocks at Gem Park and at Iron Mountain likely share a common origin.

\section{OTHER ROCKS OF THE COMPLEX}

Lensoid, conformable bodies rich in opaque minerals were mapped by Parker and Sharp (1970) along the contacts of clinopyroxene adcumulates and plagioclaseclinopyroxene orthocumulates mainly in the southern and southeastern parts of the Gem Park Complex. These rocks are best described as magnetite orthocumulates and they typically contain more than $\mathbf{9 5}$ percent euhedral magnetite and minor amounts of green spinel, pale-yellow-green biotite, and interstitial finegrained aggregates of silicate minerals. These syngenetic rocks are part of the layered sequence and are similar to the magnetite-rich rocks at the Iron Mountain mine.

Near the center of the complex a small, shallow pit exposes nepheline syenite pegmatite that most likely intrudes the mafic-ultramafic rocks (Parker and Sharp, 1970 , p. 6). These coarse-grained rocks contain untwinned and microperthitic potassic feldspar, nepheline, aegirine-augite, several amphiboles, including redbrown kaersutite and green hornblende, sphene, muscovite, apatite, opaque minerals, albite, and sodalite(?). Parker and Sharp (1970) also noted the presence of natrolite and analcite.

The mafic-ultramafic rocks at Gem Park are intruded by several dikes of lamprophyre and syenite porphyry. These types of dikes are found throughout the Wet Mountains area and have been described by Heinrich and Dahlem (1969); dikes at Gem Park were also discussed by Parker and Sharp (1970). Dikes and irregularly shaped intrusions of carbonatite also intrude the rocks of the Gem Park Complex as well as the Precambrian host rocks; these intrusions also were discussed by Parker and Sharp (1970).

\section{COMPLEX AT DEMOGRAT GREEK}

The complex at Democrat Creek is about $14 \mathrm{~km}$ east of the Gem Park Complex and $7 \mathrm{~km}$ southeast of the McClure Mountain Complex. It is a maximum of 4.5 $\mathrm{km}$ along a northwest-southeast axis and $3 \mathrm{~km}$ along a northeast-southwest axis (fig. 2).

Rocks of the complex at Democrat Creek were partly mapped by Christman and others (1954), who referred to them as "metamorphosed gabbroic and ultramafic rocks," "breccia," and "albite syenite." This reference appears to be the first mention of the complex at Democrat Creek, although the associated mafic-ultramafic rocks were considered to be Precambrian in age and therefore not part of the complex. Christman and others (1954) reported an age of 595 m.y. by the Larsen zircon method. Essentially the same data were pre- 
sented by Singewald and Brock (1956), Christman and others (1959), and Brock and Singewald (1968). Parker and Hildenbrand (1963), who mentioned the albite syenite intrusion and the 595-m.y. date, suggested that the syenite at Democrat Creek and the rocks of the McClure Mountain Complex are probably the same age. Heinrich and Dahlem (1966) coined the name "Democrat Creek complex" and related the complex to the McClure Mountain and Gem Park Complexes. They reinterpreted the "metamorphosed gabbroic and ultramafic rocks" of Christman and others (1954) as resembling the gabbros of the other complexes and therefore as being part of the complex at Democrat Creek in the sequence gabbro, breccia, albite syenite, alkalic dikes, and thorium veins and carbonatites. Armbrustmacher (1979) noted that close examination of rocks of the complex at Democrat Creek reveals more differences than similarities between these rocks and those of the McClure Mountain and Gem Park Complexes.

Most of the rocks in the complex at Democrat Creek are leucocratic, and they show different types of textures and grain sizes. The contact of the leucocratic rocks with the Precambrian host rocks is marked by a breccia zone in some places. The mafic-ultramafic rocks of the complex appear to be restricted to the southern part of the complex. Several satellitic intrusions of leucocratic rock also surround the main part of the complex. Rocks of the complex are cut by a quartz-barite-thorite vein and by several syenitic dikes, but neither carbonatite dikes nor red syenite dikes have been found within the complex.

\section{MAFIC-ULTRAMAFIC ROCKS}

The most significant petrographic aspect of the maficaltramafic rocks, from outcrops south of the large quartz syenite intrusion, is the association of two pyroxenes-a calcium-rich clinopyroxene and a calcium-poor orthopyroxene. According to Wilkinson (1974), this association is characteristic of tholeitic, not alkaline, mafic rocks. On the basis of petrographic data, the clinopyroxene is augite and the faintly pleochroic orthopyroxene is hypersthene. Plagioclase either is absent, as in the pyroxenites, or constitutes nearly 25 percent of the rock, as in the gabbros. The plagioclase is clear, but is saussuritized to varying degrees. Oriented rodlike inclusions of apatite (?) occur in some plagioclase grains. Interstitial to the pyroxenes, and having the appearance of intercumulus material, is a pale-yellowish-green, faintly pleochroic amphibole that has optical and X-ray-diffraction properties similar to those of minerals in the tremolite-actinolite group. Sparse biotite, pleochroic in shades of green and brown, is also interstitial; apatite and magnetite are accessory minerals. Evidence of stratification is not obvious at the outcrop.

Compared with mafic-ultramafic rocks from the McClure Mountain and Gem Park Complexes, which contain minerals typical of alkaline mafic rocks, the mafic-ultramafic rocks from the complex at Democrat Creek contain a mineral assemblage characteristic of tholeiitic mafic rocks. Chemical data discussed later verify the tholeiitic nature of these rocks.

\section{QUARTZ SYENITE}

The leucocratic rocks in the complex at Democrat Creek have been called "albite syenite" by Christman and others (1959) and Heinrich and Dahlem (1966), "medium-grained syenite" by Scott and others (1976), "fine- to medium-grained syenite" by Taylor and others (1975b), and "quartz syenite" by Olson and others (1977). In this report, they are termed "quartz syenites." In the field, several varieties of rocks, mainly light gray, tan, and pink, are present: medium-grained rocks with equigranular textures, coarsely crystalline rocks with pegmatitic textures, and medium-grained porphyritic rocks, all intermixed at about the $1-10 \mathrm{~m}$ scale. In hand specimen, the pegmatitic rocks have gradational contacts with the equigranular rocks; in some places, the porphyritic rocks cut the pegmatitic rocks. Whether several episodes of intrusion are represented or whether localized variations in crystallization, such as abundances of volatile constituents, are present is not clear. Lithologic variations also result from variations in modal mineralogy. The abundance of mafic minerals varies from near zero to moderately abundant at the outcrop; in some specimens, the mafic minerals are acicular. At some localities, quartz appears to be abundant in the hand specimens, but at other localities quartz is difficult to identify. Xenoliths of both mafic rocks and granitic gneiss have been observed, sometimes at localities distant from contacts with the country rock. The mafic rocks are altered, and perhaps represent fenitized equivalents of the mafic-ultramafic rocks, such as those occurring south of the leucocratic part of the complex. Fenitization of the country rock Precambrian granitic gneisses adjacent to rocks of the complex is not obvious.

Quartz, which usually occurs as an interstitial mineral, ranges from 2 to 32 percent by volume. Small fluid inclusions containing daughter minerals are abundant in the quartz, which partly replaces the feldspars.

The feldspars, microperthite, microcline, and albite are the most abundant constituents of the quartz syenites; they collectively range from 64 to over 93 percent. Microperthite is the most abundant mineral, but 
microcline is absent in some samples. Albite may replace microcline and form discrete grains chiefly interstitial to larger microperthite grains. Microperthite ranges from 32 to 83 percent by volume, microcline ranges from 0 to 20 percent, and albite ranges from 6 to nearly 20 percent. Sodic amphibole in the quartz syenites ranges from 0 to 10 percent, has a small extinction angle, is biaxial with a moderate $2 \mathrm{~V}$, and is pleochroic olive green to dark blue. This mineral appears to be a member of the eckermannite-arfvedsonite group. Aegirine(?) and riebeckite are sparse. Biotite tends to be altered and replaced, and is pleochroic through shades of reddish brown. Zircon, fluorite, magnetite, and sparse sphene are accessory minerals that occur in amounts of less than 1 percent.

Plots of modal data on a QAPF diagram (fig. 14) show that most of the quartz syenites plot in the syenite and alkali syenite fields; two of the quartz-rich varieties plot in the granite field.

\section{CARBONATITES}

Carbonatites associated with alkaline rocks of the McClure Mountain and Gem Park Complexes and the complex at Democrat Creek can be classified into two groups, replacement and primary magmatic, on the basis of distinctive petrographic differences (Armbrustmacher, 1979). These two groups also show distinctive differences in mineralogy and geochemistry. Textures of replacement carbonatites indicate nearly complete pseudomorphous replacement of originally porphyritic or hypidiomorphic-granular igneous dike rocks by carbonate minerals. They contain an element suite characteristic of carbonatites as well as a traceelement signature indicative of a mafic silicate precursor. Minerals that contain thorium, niobium, and rareearth elements as essential constituents generally are rare. Primary magmatic carbonatites, which do not show the distinctive replacement textures, are also enriched in elements characteristic of carbonatites, but contain greater average amounts of these elements than do replacement carbonatites. Thorite, bastnaesite, synchysite, ancylite, and monazite are chiefly responsible for the high thorium and rare-earth-element content of these rocks compared to that in other igneous rocks. Primary magmatic carbonatites are spatially more closely associated with the alkaline intrusions than are replacement carbonatites, which have a somewhat wider distribution. Field data and $\delta^{18} \mathrm{O}$ and $\delta^{13} \mathrm{C}$ values support an igneous origin for primary magmatic carbonatites; isotopic values indicate that the carbonatite replacing the earlier alkaline dikes also was derived from igneous sources. Exchange of isotopes between both types of carbonatite and nonigneous reservoirs appears to be minimal.
Abundances of rare-earth elements and niobium in carbonatites of the Wet Mountains area are somewhat lower than those at other carbonatite localities that contain economic or near-economic concentrations. Thorium is more abundant in spatially related vein-type deposits than in the carbonatites.

\section{AGES OF THE COMPLEXES}

The first known age determinations of Wet Mountains alkaline rocks were reported by Jaffe and others (1959). Two samples of nonmetamict zircon from the "albite syenite" at Democrat Creek gave ages of 580 and $601 \mathrm{~m} . \mathrm{y}$. by the Larsen zircon method. A K-Ar age reported by Brock and Singewald (1968) for biotite from the syenite at Democrat Creek is $500 \pm 25 \mathrm{~m} . \mathrm{y}$. Fenton and Faure (1970) calculated a whole-rock $\mathrm{Rb}-\mathrm{Sr}$ isochron for rocks from the McClure Mountain Complex that indicated an age of $517 \pm 14 \mathrm{~m}$.y. and an initial ${ }^{87} \mathrm{Sr} /$ ${ }^{86} \mathrm{Sr}$ ratio of $0.7059 \pm 0.0003$. Using a variety of dating techniques, Olson and others (1977) reported ages from a variety of alkaline rocks. Their results for rocks from the McClure Mountain Complex are: 520 m.y. (average hornblende $\mathrm{K}-\mathrm{Ar}$ age), $521 \mathrm{~m} . \mathrm{y}$. (Rb-Sr isochron), 508 m.y. (average biotite K-Ar ages), and 506 m.y. (sphene fission-track age); the quartz syenite in the complex at Democrat Creek has average K-Ar ages of 512 m.y. (biotite) and 534 m.y. (hornblende). Their data showed that red syenite dikes associated with rocks of the three complexes have an age of $495 \mathrm{~m} . \mathrm{y}$. ( $\mathrm{Rb}-\mathrm{Sr}$ isochron), but attempts to date rocks from the Gem Park Complex gave unsuitable results (Olson and others, 1977, p. 683).

In more recent studies (Armbrustmacher and Hedge, 1982), whole-rock isochrons were prepared for leucocratic rocks from the McClure Mountain Complex and for the complex at Democrat Creek by C. E. Hedge of the U.S. Geological Survey. The hornblende-biotite syenites and nepheline syenites from the McClure Mountain Complex lie along the same whole-rock isochron (fig. 21), and, although field relationships indicate that the nepheline syenite is younger than the hornblende-biotite syenite, these differences cannot be resolved with these data. The age of these syenites is $535 \pm 5$ m.y.; and the initial ${ }^{87} \mathrm{Sr} /{ }^{86} \mathrm{Sr}$ ratio is $0.7037 \pm 0.0002$. The quartz syenites from the complex at Democrat Creek show a greater variation in $\mathrm{Rb} / \mathrm{Sr}$ ratios; the whole-rock isochron gives an age of $511 \pm 8$ m.y. and an initial ${ }^{87} \mathrm{Sr} /{ }^{86} \mathrm{Sr}$ ratio of $0.7032 \pm 0.0002$ (fig. 22). Thus, an age difference of about $24 \mathrm{~m} . \mathrm{y}$. exists between the syenites in the McClure Mountain Complex and the quartz syenites in the complex at Democrat Creek. The relative and absolute age relationships of the rocks of the Wet Mountains area are given in table 1. 


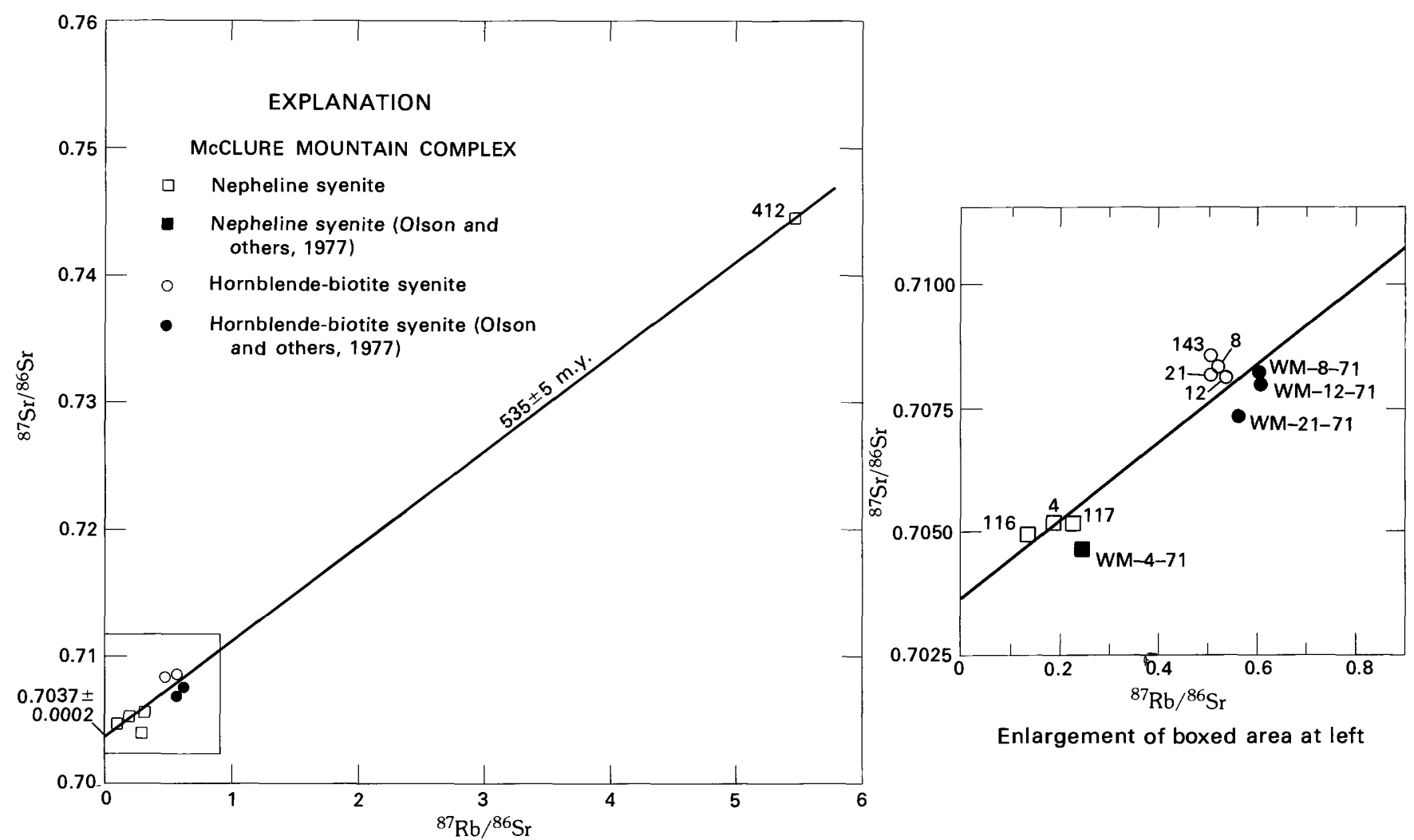

Figure 21.-Whole-rock isochron of nepheline syenites of McClure Mountain Complex.

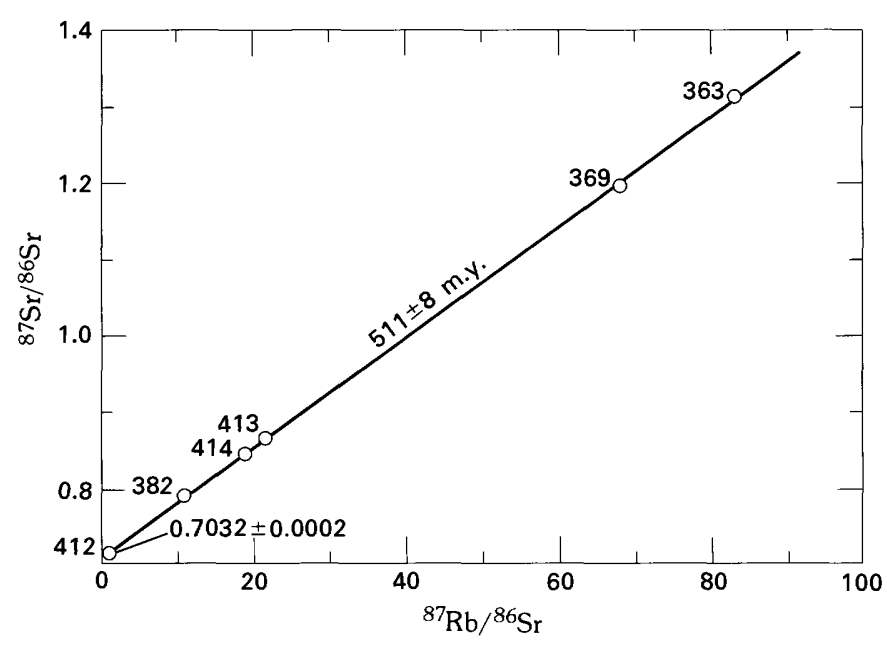

FIGURE 22.-Whole-rock isochron of quartz syenites of the complex at Democrat Creek.

\section{GEOCHEMISTRY}

Discussion of the geochemistry of the alkaline rock complexes is based on data from several sources. Majorelement analyses of mafic-ultramafic rocks from the Gem Park Complex are from Parker and Sharp (1970, table 1), and analyses of rocks from the Iron Mountain part of the McClure Mountain Complex, as well as minor- and trace-element contents of some of the rocks are from Shawe and Parker (1967, table 3). The remaining whole-rock analyses are new. Geochemical data based mainly on carbonatites have been presented by Armbrustmacher (1979) and Armbrustmacher and Brownfield (1978). Radiometric ages of rocks in the complexes have been reported by Jaffe and others (1959, p. 127), Fenton and Faure (1970), Olson and Marvin (1971), and Armbrustmacher and Hedge (1982). Additonal minor-element and isotopic data have been reported by Roden and Cullers (1976) and Armbrustmacher, Brownfield, and Osmonson (1979). The major- and minor-element distributions in the alkaline rocks have been summarized by Armbrustmacher (1980).

\section{MAJOR ELEMENTS \\ MAFIC-ULTRAMAFIC ROCKS}

Chemical and normative data of mafic-ultramafic rocks from the Iron Mountain area of the McClure Mountain Complex are given in table 2; similar data for mafic-ultramafic rocks from the Gem Park Complex and the complex at Democrat Creek are given in table 3. Analyses 1-9 in table 2 are from Shawe and Parker (1967, table 3), except that the norms have been recalculated from analyses adjusted to 100 percent. Analysis 
TABLE 1.-Relative and absolute age relationships of rocks of the Wet Mountains area, Colorado

\begin{tabular}{|c|c|c|}
\hline $\begin{array}{r}\text { Geolog } \\
\text { ages }\end{array}$ & Rock types & $\begin{array}{l}\text { Absolute } \\
\text { ages }\end{array}$ \\
\hline 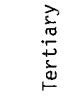 & Volcaniclastic rocks & \\
\hline 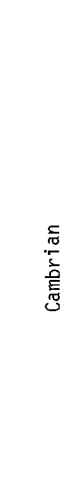 & $\begin{array}{l}\text { Quartz-barite-thorite veins; various leucocratic dikes } \\
\text { Complex at Democrat Creek: } \\
\qquad \begin{array}{r}\text { puartz syenite } \\
\text { mafic-ultramafic rocks }\end{array} \\
\begin{aligned} & \text { Carbonatites, red syenites, lamprophyres (?) } \\
& \text { McClure Mountain Complex: } \text { nepheline syenite } \\
& \text { nornblende-biotite syenite } \\
& \text { mafic nepheline-clino- } \\
& \text { pyroxene rock }\end{aligned} \\
\text { Gem Park Complex: } \\
\text { Gem Park and McClure Mountain cumulates syenite pegmatite }\end{array}$ & $\begin{array}{l}535 \text { m.y. } \\
535 \text { m.y. }\end{array}$ \\
\hline 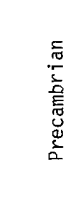 & $\begin{array}{l}\text { Silver Plume or Proterozoic } Y \text { age: granitic intrusive } \\
\text { rocks } \\
\text { Boulder Creek or Proterozoic } X \text { age: granitic } \\
\text { intrusive rocks } \\
\text { Proterozoic } X \text { metamorphic rocks }\end{array}$ & $\begin{array}{l}1,450 \text { m.y. } \\
1,720 \text { m.y. }\end{array}$ \\
\hline
\end{tabular}

10 (table 2), a plagioclase-clinopyroxene orthocumulate, was obtained by Shawe and Parker but was not included in their 1967 Iron Mountain report. In table 3, the two analyses of Gem Park rocks are from Parker and Sharp (1970, table 1); the norms also have been recalculated as in table 2. The four analyses of Democrat Creek mafic-ultramafic rocks are new.

None of the mafic-ultramafic rocks from the McClure Mountain and Gem Park Complexes and only one from the complex at Democrat Creek contain normative quartz. Seven rocks from McClure Mountain, both rocks from Gem Park, and no rocks from Democrat Creek contain normative nepheline. Only three rocks from McClure Mountain contain normative hypersthene, all in amounts of less than 3 percent; neither of the rocks from Gem Park contains normative hypersthene, but all rocks from Democrat Creek contain normative hypersthene in amounts exceeding 37 percent. All McClure Mountain rocks contain normative olivine in variable amounts; Gem Park rocks contain some normative olivine, and Democrat Creek rocks contain normative olivine in amounts of less than 2.1 percent. According to Wilkinson $(1974$, p. 67$)$, basaltic rocks containing normative nepheline and normative olivine are alkali basaltic types, but rocks containing normative hy- persthene are saturated tholeiitic basaltic types. Rocks from the McClure Mountain and Gem Park Complexes appear to be alkali basaltic, whereas rocks from the complex at Democrat Creek appear to be tholeiitic basaltic. Figure 23, which is modified from Currie (1976, fig. 1), incorporates the boundary line conventionally used to partition alkaline basalts from tholeiitic or subalkaline basalts (MacDonald and Katsura, 1964). The plagioclase-bearing rocks from the McClure Mountain and Gem Park Complexes plot as members of the alkali basalt family. Plagioclase-poor pyroxenitic rocks plot as subalkaline rocks because of their deficiency in $\mathrm{Na}_{2} \mathrm{O}+\mathrm{K}_{2} \mathrm{O}$, and plagioclase-rich anorthositic rocks plot near the boundary. Mafic-ultramafic rocks from the complex at Democrat Creek cluster together, well within the subalkaline rock field. Plots of agpaitic index (molecular proportions $\mathrm{Na}+\mathrm{K} / \mathrm{Al}$ ) versus weight percent $\mathrm{SiO}_{2}$ (fig. 24) of Gem Park rocks place them in the alkaline basalt family, whereas McClure Mountain rocks occur within the alkaline basalt family and subalkaline rocks fields regardless of lithologic type. The Democrat Creek rocks again cluster in the subalkaline rock field.

On the basis of whole-rock chemical composition, the mafic-ultramafic rocks of the McClure Mountain and Gem Park Complexes appear to be similar to and to be derived from an alkaline basalt parent. Wager and Brown $(1967$, p. 540$)$ stated that they “***are not aware of any major layered intrusion likely to have stemmed from an alkali-basalt parent magma." Currie $(1976$, p. 5) also stated that "*** plutonic complexes of alkaline basalt composition are rare, although subvolcanic complexes such as the Monteregian Hills are common." However, Brown (1973) pointed out that layered intrusions of alkaline basalt parentage, such as Lilloise in east Greenland, are not unknown, and Currie (1976) described a few occurrences in Canada in addition to that in the Monteregian Hills. Mafic-ultramafic rocks at Democrat Creek appear to have subalkaline, saturated, tholeiitic affinities.

\section{LEUCOCRATIC ROCKS}

Chemical and normative data of hornblende-biotite syenites and nepheline syenites from the McClure Mountain Complex are given in table 4, and those of quartz syenites from the complex at Democrat Creek and of nepheline syenite pegmatite from the Gem Park Complex are given in table 5. The quartz syenites from the McClure Mountain Complex that have the WM sample-number prefix were collected by R. L. Parker and W. N. Sharp of the U.S. Geological Survey; the syenites from Democrat Creek were collected for this study. None of the analyses has been published previously. 
TABLE 2.-Chemical and normative data of mafic-ultramafic rocks from the Iron Mountain area of the McClure Mountain Complex, south-central Colorado

[Values in weight percent. Leaders (---) indicate no data. Analyses 1-9 are from Shawe and Parker, 1967, table 3; analysis 10 by Shawe and Parker, unpublished data, 1980]

\begin{tabular}{|c|c|c|c|c|c|c|c|c|c|c|}
\hline $\begin{array}{c}\text { Analysis No.* } \\
\text { Field No. }\end{array}$ & $\frac{1}{I M-10-64}$ & $\begin{array}{c}2 \\
W M-64-827\end{array}$ & $\begin{array}{c}3 \\
\text { IM-20-64 }\end{array}$ & $\begin{array}{c}4 \\
W M-62-73\end{array}$ & $\begin{array}{c}5 \\
W M-64-828\end{array}$ & $\begin{array}{c}6 \\
W M-64-829\end{array}$ & $\begin{array}{c}7 \\
\text { WM- } 64-824\end{array}$ & $\begin{array}{c}8 \\
I M-28-64\end{array}$ & $\stackrel{9}{1 M-31-64}$ & $\begin{array}{c}10 \\
W M-64-896 A\end{array}$ \\
\hline \multicolumn{11}{|c|}{ Chemical Compositions } \\
\hline $\mathrm{SiO}_{2}$ & 40.31 & 42.81 & 43.28 & 46.74 & 46.88 & 46.99 & 44.00 & 46.07 & 51.05 & 46.59 \\
\hline $\mathrm{Al}_{2} \mathrm{O}_{3}$ & 7.31 & 17.08 & 24.82 & 21.10 & 11.18 & 11.47 & 9.67 & 8.73 & 26.94 & 23.32 \\
\hline $\mathrm{Fe}_{2} \mathrm{O}_{3}$ & 2.81 & 5.53 & 1.54 & 1.51 & 3.47 & 3.09 & 4.36 & 4.07 & .80 & 1.92 \\
\hline $\mathrm{Fe} 0$ & 15.61 & 7.49 & 3.22 & 4.93 & 5.12 & 4.73 & 4.95 & 3.83 & 1.08 & 3.01 \\
\hline $\mathrm{MgO}$ & 25.22 & 6.53 & 9.41 & 7.48 & 10.61 & 10.68 & 13.66 & 11.95 & 1.29 & 4.89 \\
\hline $\mathrm{CaO}$ & 5.34 & 13.59 & 12.44 & 13.62 & 19.47 & 20.02 & 20.01 & 21.42 & 12.47 & 15.26 \\
\hline $\mathrm{Na}_{2} \mathrm{O}$ & .88 & 2.18 & 1.55 & 2.41 & 1.07 & .94 & .47 & .94 & 3.78 & 2.69 \\
\hline $\mathrm{K}_{2} \mathrm{O}$ & .14 & .22 & .19 & .21 & .09 & .07 & .12 & .18 & .62 & .26 \\
\hline $\mathrm{H}_{2} \mathrm{O}$ & 1.24 & .69 & 2.89 & .74 & .36 & .29 & .69 & .48 & 1.00 & .70 \\
\hline $\mathrm{TiO}_{2}$ & .54 & 2.57 & .11 & .72 & 1.83 & 1.71 & 1.57 & 1.81 & .28 & .74 \\
\hline $\mathrm{P}_{2} \mathrm{O}_{5}$ & .05 & .37 & .03 & .13 & .08 & .03 & .04 & .06 & .02 & .14 \\
\hline Mn0 & .29 & .15 & .07 & .10 & .13 & .13 & .13 & .11 & .03 & .07 \\
\hline $\mathrm{CO}_{2}$ & .38 & .78 & .39 & .33 & .02 & .03 & .56 & .37 & .48 & .57 \\
\hline $\mathrm{Cl}$ & .01 & .02 & .02 & .03 & -- & -- & .01 & .02 & .01 & .03 \\
\hline$F$ & .01 & .04 & .01 & .02 & .02 & .02 & .02 & .04 & .02 & .16 \\
\hline \multicolumn{2}{|c|}{ Total-- 100.14} & 100.05 & 99.97 & 100.07 & 100.33 & 100.20 & 100.26 & 100.08 & 99.87 & 100.35 \\
\hline \multicolumn{11}{|c|}{ Normative Composition } \\
\hline C & -- & -- & 0.47 &.- & -- & --- & -- & --- & 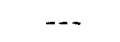 & $\cdots$ \\
\hline Or & 0.83 & 1.30 & 1.12 & 1.24 & 0.53 & 0.41 & -- & -- & 3.67 & 1.53 \\
\hline $\mathrm{Ab}$ & 7.36 & 18.24 & 12.97 & 18.05 & 4.14 & 2.66 & $\cdots$ & $\cdots$ & 31.95 & 17.24 \\
\hline An & 15.60 & 36.23 & 59.02 & 46.22 & 25.35 & 26.82 & 23.90 & 19.13 & 54.82 & 50.73 \\
\hline LC & $\cdots$ & -- & -- & --- & --- & -- & .56 & .83 & -- & -- \\
\hline $\mathrm{Ne}$ & $\cdots$ & .03 & -- & 1.14 & 2.65 & 2.86 & 2.11 & 4.22 & -- & 2.83 \\
\hline $\mathrm{HI}$ & .02 & .03 & .03 & .05 & -- & -- & .02 & .03 & .02 & .05 \\
\hline Wo & 3.38 & 9.92 & -- & 7.64 & 29.30 & 29.98 & 26.70 & 33.53 & 1.60 & 7.99 \\
\hline En & 3.80 & 6.89 & .28 & 5.17 & 22.85 & 23.52 & 21.56 & 28.34 & 3.02 & 5.86 \\
\hline Fs & 1.57 & 2.21 & .06 & 1.89 & 3.25 & 3.14 & 1.99 & .84 & .86 & 1.37 \\
\hline Fo & 41.29 & 6.56 & 16.23 & 9.42 & 2.44 & 2.12 & 8.67 & .98 & .14 & 4.40 \\
\hline $\mathrm{Fa}$ & 18.83 & 2.32 & 3.50 & 3.79 & .38 & .31 & .88 & .03 & .04 & 1.13 \\
\hline Cs & -- & $-\cdots$ &.- & -- & - &.- & 2.25 & 1.16 & -- & -.- \\
\hline Mt & 4.07 & 8.01 & 2.23 & 2.19 & 5.02 & 4.47 & 6.30 & 5.90 & 1.16 & 2.77 \\
\hline [1] & 1.02 & 4.88 & .21 & 1.37 & 3.46 & 3.24 & 2.97 & 3.44 & .53 & 1.40 \\
\hline$A p$ & .12 & .88 & .07 & .31 & .19 & .07 & .09 & .14 & .05 & .33 \\
\hline $\mathrm{Fr}$ & .01 & .01 & .02 & .02 & .03 & .04 & .03 & .07 & .04 & .30 \\
\hline $\mathrm{Cc}$ & .86 & 1.77 & .89 & .75 & .04 & .07 & 1.27 & .84 & 1.09 & 1.29 \\
\hline Di & 6.52 & 19.02 &.-- & 14.70 & 55.40 & 56.63 & 50.25 & 62.72 & 3.05 & 15.22 \\
\hline $\mathrm{Hy}$ & 2.23 & --- & .34 & -. & --- & -- & --- & --- & 2.43 & --- \\
\hline 01 & 60.12 & 8.88 & 19.73 & 13.22 & 2.82 & 2.43 & 9.55 & 1.01 & .18 & 5.53 \\
\hline
\end{tabular}

*Analysis Nos. are:

1. Clinopyroxene-plagioclase-olivine orthocumulate.

6. Clinopyroxene-plagioclase cumulate.

2. Plagioclase-clinopyroxene orthocumulate.

3. Plagioclase-olivine orthocumulate.

4. Plagioclase-clinopyroxene-ol ivine cumulate.

7. Pyroxenite from discordant intrusion.

8. Pyroxenite from discordant intrusion.

5. Clinopyroxene-plagioclase cumulate.

9. Anorthosite from discordant intrusion.

10. Plagioclase-clinopyroxene orthocumulate. 
TABLE 3.-Chemical and normative data of mafic-ultramafic rocks from the Gem Park Complex and the complex at Democrat Creek, south-central Colorado

[Values in weight percent. Leaders (---) indicate no data]

\begin{tabular}{|c|c|c|c|c|c|c|}
\hline \multicolumn{3}{|c|}{ Gem Park Complex } & \multicolumn{4}{|c|}{ Complex at Democrat Creek } \\
\hline $\begin{array}{l}\text { Analysis No.* } \\
\text { Field No. } \mathrm{W}\end{array}$ & 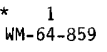 & $\begin{array}{c}2 \\
W M-64-875\end{array}$ & $\begin{array}{c}3 \\
75 A-299\end{array}$ & $\begin{array}{c}4 \\
75 A-300\end{array}$ & $\begin{array}{c}5 \\
75 A-302\end{array}$ & $\begin{array}{c}6 \\
75 A-297\end{array}$ \\
\hline \multicolumn{7}{|c|}{ Cnemical Composition } \\
\hline $\mathrm{SiO}_{2}$ & 39.16 & 45.31 & 52.8 & 52.6 & 53.1 & 53.4 \\
\hline $\mathrm{Al}_{2} \mathrm{O}_{3}$ & 13.72 & 7.03 & 9.3 & 4.8 & 7.4 & 4.8 \\
\hline $\mathrm{Fe}_{2} \mathrm{O}_{3}$ & 7.50 & 3.98 & 1.2 & 3.0 & .5 & 1.9 \\
\hline $\mathrm{FeO}$ & 9.79 & 6.05 & 6.5 & 6.5 & 7.8 & 7.8 \\
\hline Mgo & 6.68 & 12.84 & 16.8 & 22.2 & 18.2 & 22.5 \\
\hline $\mathrm{CaO}$ & 12.12 & 19.99 & 10.5 & 8.2 & 10.1 & 7.5 \\
\hline $\mathrm{Na}_{2} \mathrm{O}$ & 2.56 & .82 & 1.3 & .59 & .97 & .67 \\
\hline $\mathrm{K}_{2} \mathrm{O}$ & .45 & .17 & .22 & .15 & .11 & .34 \\
\hline $\mathrm{H}_{2} \mathrm{O}$ & 1.16 & .84 & .82 & .57 & .68 & .66 \\
\hline $\mathrm{TiO}_{2}$ & 4.42 & 2.50 & .34 & .39 & .45 & .38 \\
\hline $\mathrm{P}_{2} \mathrm{O}_{5}$ & 1.06 & .14 & .08 & .05 & .08 & .09 \\
\hline $\mathrm{MnO}$ & .21 & .15 & .13 & .17 & .13 & .18 \\
\hline $\mathrm{CO}_{2}$ & .99 & .40 & .02 & .01 & -- & .04 \\
\hline $\mathrm{Cl}$ & .04 & .02 & -- & --- & --- & --- \\
\hline $\mathrm{F}$ & .12 & .04 & $\cdots$ & --- & --- & $--\cdot$ \\
\hline Total -- & 99.98 & 100.28 & 100.0 & 99.2 & 99.5 & 100.3 \\
\hline \multicolumn{7}{|c|}{ Normative Composition } \\
\hline$Q$ & --- & --- & --- & 0.5 & $\cdots$ & -- \\
\hline or & 2.66 & 1.00 & 1.3 & .9 & .7 & 2.0 \\
\hline$A b$ & 18.84 & .12 & 11.0 & 5.0 & 8.2 & 5.7 \\
\hline An & 24.78 & 15.04 & 18.9 & 10.1 & 15.6 & 9.1 \\
\hline $\mathrm{Ne}$ & 1.37 & 3.60 & --- & -- & -- & -- \\
\hline $\mathrm{HI}$ & .07 & .03 & --- & $-\infty$ & --- & --- \\
\hline Wo & 9.18 & 33.50 & 13.6 & 12.7 & 14.3 & 11.4 \\
\hline En & 6.49 & 26.45 & 40.0 & 55.7 & 44.8 & 53.5 \\
\hline Fs & 1.90 & 3.29 & 10.1 & 9.2 & 13.3 & 11.9 \\
\hline Fo & 7.11 & 3.81 & 1.3 & --- & .5 & 1.6 \\
\hline $\mathrm{Fa}$ & 2.30 & .52 & .4 & -- & .2 & .4 \\
\hline Mt & 10.88 & 5.76 & 1.7 & 4.4 & .7 & 2.7 \\
\hline Il & 8.40 & 4.74 & .6 & .7 & .9 & .7 \\
\hline Ap & 2.51 & .33 & .2 & .1 & .2 & .2 \\
\hline $\mathrm{Fr}$ & .05 & .06 & -.- & -- & -.- & --- \\
\hline$C_{c}$ & 2.25 & .91 & .04 & .02 & -- & .09 \\
\hline$D i$ & 17.57 & 63.23 & 25.9 & 24.1 & 27.4 & 21.6 \\
\hline $\mathrm{Hy}$ & -.. & -.- & 37.8 & 53.5 & 45.0 & 55.2 \\
\hline 01 & 9.41 & 4.33 & 1.7 & --- & .7 & 2.1 \\
\hline
\end{tabular}

*Analysis Nos, are:

1. Plagioclase-clinopyroxene orthocumulate (Parker and Sharp, 1970, table 1). Clinopyroxene adcumulate (Parker and Sharp, 1970, Table 1) Gabbro (analyst Floyd Brown).

Pyroxenite (analyst Floyd Brown)

6yroxentte (analyst Z. A. Haml in)

All hornblende-biotite syenites and nepheline syenites from McClure Mountain contain normative nepheline (less than 1 percent and 9-25 percent respectively). However, none of the rocks contains normative quartz. The syenites from Democrat Creek typically contain abundant normative quartz and lack normative nepheline. Three feldspars exist in the norms of hornblende-biotite syenite and nepheline syenite from McClure Mountain: normative $\mathrm{Ab}>\mathrm{Or}>\mathrm{An}$ and norma-

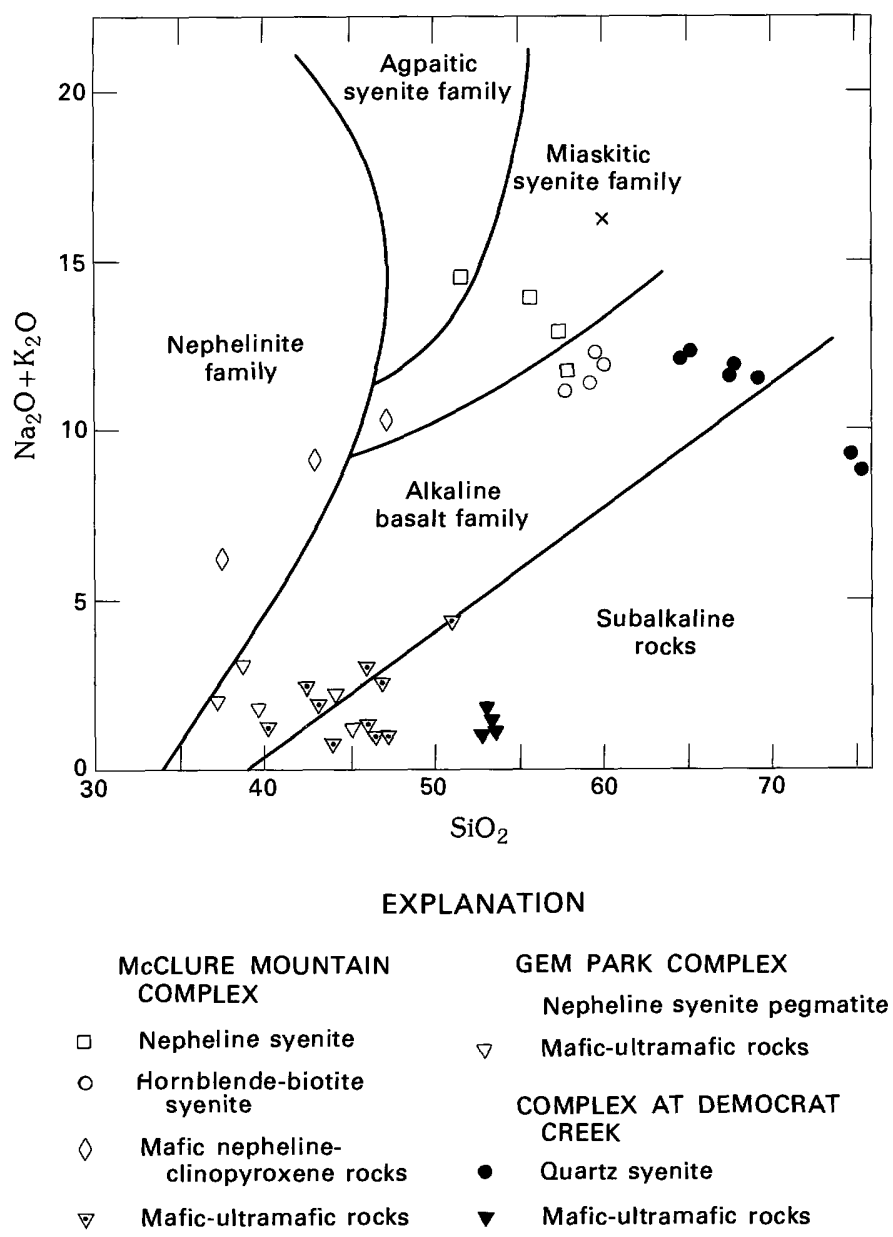

FIGURE 23.-Plots of weight-percent alkalies versus weight-percent silica for samples from the McClure Mountain Complex, Gem Park Complex, and complex at Democrat Creek (modified from Currie, 1976, fig. 1).

tive $\mathrm{Or}>\mathrm{Ab}>\mathrm{An}$, respectively in most norms. Nearly all the quartz syenites from Democrat Creek contain two normative feldspars with $\mathrm{Ab}>\mathrm{Or}$. The $\mathrm{CaO}$ content of both hornblende-biotite syenites and nepheline syenites totals several percent by weight. The $\mathrm{CaO}$ content of quartz syenites, which rarely exceeds 1 percent, is so low in several samples that occurs not enough $\mathrm{CaO}$ to combine with all the fluorine to make normative $\mathrm{Fr}$ (fluorite) in the norm; therefore, excess fluorine must be listed as normative $\mathrm{F}$ (fluorine). This relation reflects the abundance of modal fluorite and the paucity of modal plagioclase in the quartz syenites from Democrat Creek. All the hornblende-biotite syenites and nepheline syenites are devoid of normative hypersthene, whereas all the quartz syenites contain it. The presence of normative olivine as well as normative nepheline in the hornblende-biotite syenites and nepheline syenites indicates that they are chemically undersaturated; neither normative olivine nor normative nepheline occurs in quartz syenites. 


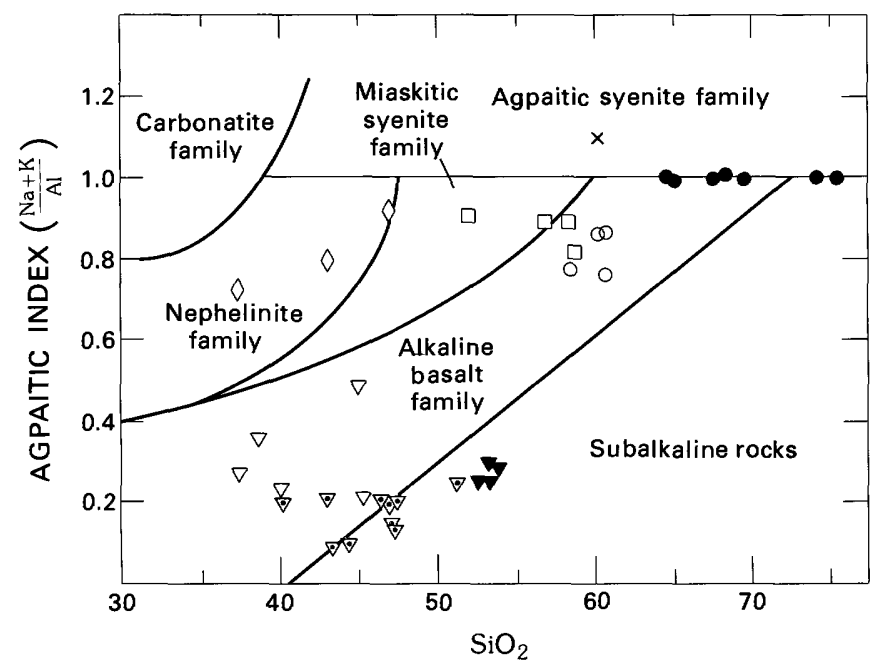

EXPLANATION

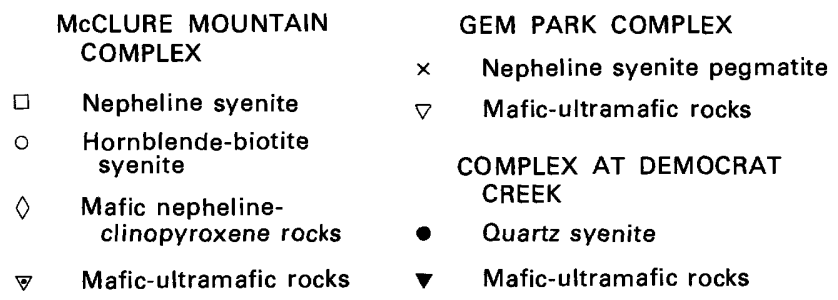

FIGURE 24.-Plots of agpaitic index versus weight-percent silica for samples from the McClure Mountain Complex, Gem Park Complex, and complex at Democrat Creek (modified from Currie, 1976, fig. 2).

Plots of the leucocratic rocks on a $\mathrm{Na}_{2} \mathrm{O}+\mathrm{K}_{2} \mathrm{O}$ versus $\mathrm{SiO}_{2}$ diagram (fig. 23) show that the nepheline syenites from McClure Mountain generally contain somewhat more $\mathrm{Na}_{2} \mathrm{O}+\mathrm{K}_{2} \mathrm{O}$ and slightly less $\mathrm{SiO}_{2}$ than do the hornblende-biotite syenites; the values overlap slightly. The quartz syenites of Democrat Creek, because of their higher $\mathrm{SiO}_{2}$ content, tend to plot away from the syenites from the McClure Mountain Complex. One sample of nepheline syenite pegmatite from Gem Park (analyzed by Roden, 1977) contains considerably more $\mathrm{Na}_{2} \mathrm{O}+\mathrm{K}_{2} \mathrm{O}$ than do the other syenites. All the hornblende-biotite syenites plot within the alkali basalt family field and are homogeneous in distribution; the nepheline syenites plot within various fields and are somewhat heterogeneous in distribution; and the quartz syenites from Democrat Creek plot in the alkaline basalt family and subalkaline rocks fields and also are heterogeneous. These plots do not provide unique solutions to problems of leucocratic rock genetic affiliations. Plots of leucocratic rocks on an agpaitic index versus $\mathrm{SiO}_{2}$ diagram (fig. 24) provide nearly the same information. The nepheline syenite pegmatite at Gem Park is the only rock that plots in the agpaitic syenite family field.
These chemical data alone show distinct differences between quartz syenites from Democrat Creek and the syenites from the McClure Mountain Complex. Although somewhat more subtle, chemical differences also exist between the hornblende-biotite syenites and nepheline syenites at McClure Mountain. The small exposure of nepheline syenite pegmatite, represented by one analysis (table 5, No. 8), shows large differences where compared with all other leucocratic rocks.

\section{MAFIC NEPHELINE-CLINOPYROXENE ROCKS}

Chemical and normative data of mafic nephelineclinopyroxene rocks are given in table 4 . These rocks have been found only in the McClure Mountain Complex.

The $\mathrm{SiO}_{2}$ content of the mafic nephelineclinopyroxene rocks is similar to that of the maficultramafic rocks (table 2), whereas the $\mathrm{Na}_{2} \mathrm{O}$ content is similar to that of the syenites at McClure Mountain (table 4). The $\mathrm{P}_{2} \mathrm{O}_{5}$ and $\mathrm{TiO}_{2}$ content is higher than that in most of the other rock types. Comparison of the analysis with the average derived from 41 analyses of African ijolites (LeBas, 1977, p. 307) shows a number of similarities, especially in the amounts of $\mathrm{SiO}_{2}(40.01$ percent), $\mathrm{TiO}_{2}$ (2.38 percent), $\mathrm{Na}_{2} \mathrm{O}$ (7.10 percent), and $\mathrm{Na}_{2} \mathrm{O} / \mathrm{K}_{2} \mathrm{O}$ ratio (2.3). The $\mathrm{P}_{2} \mathrm{O}_{5}$ content (0.88 percent) is not similar.

Plots of the mafic nepheline-clinopyroxene rocks on a diagram of $\mathrm{Na}_{2} \mathrm{O}+\mathrm{K}_{2} \mathrm{O}$ versus $\mathrm{SiO}_{2}$ (fig. 23) show they contain more abundant alkalies but comparable amounts of $\mathrm{SiO}_{2}$ in comparison to the mafic-ultramafic rocks of McClure Mountain. These characteristics place these analyses in or near the nephelinite family field. Moreover, plots of these rocks on a diagram of agpaitic index versus $\mathrm{SiO}_{2}$ (fig. 24) also place the analyses in the nephelinite family field.

\section{ADDITIONAL OBSERVATIONS}

In the diagram of $\mathrm{Na}_{2} \mathrm{O}+\mathrm{K}_{2} \mathrm{O}$ versus $\mathrm{SiO}_{2}$ (fig. 23), rocks of comagmatic series should plot at least subparallel to the boundary separating the alkaline basalt family from the subalkaline rocks. If this is true, one can visualize that three separate rock series are illustrated: (1) the mafic-ultramafic rocks and the quartz syenites from Democrat Creek; (2) the mafic-ultramafic rocks of McClure Mountain and Gem Park Complexes and the hornblende-biotite syenites of the McClure Mountain Complex, and (3) the mafic nepheline-clinopyroxene rocks and the nepheline syenite of the McClure Mountain Complex, and perhaps the nepheline syenite pegmatite of the Gem Park Complex.

Plots of all the analyses on a diagram of differentiation index versus oxide weight percent (fig. 25) show 
TABLE 4.-Chemical and normative data of hornblende-biotite syenites, nepheline syenites, and mafic nepheline-clinopyroxene rocks, McClure Mountain Complex, south-central Colorado

[Values in weight percent. Leaders (---) indicate no data. Analyses 1-7 by Eilen Daniels; Nos. 8-10 by K. Coates and H. Smith]

\begin{tabular}{|c|c|c|c|c|c|c|c|c|c|c|}
\hline $\begin{array}{c}\text { Analys is No.* } \\
\text { Field No. }\end{array}$ & * $\frac{1}{W M-62-131}$ & WM- ${ }^{2} 2-140$ & $\begin{array}{c}3 \\
W M-62-142\end{array}$ & $\begin{array}{c}4 \\
W M-62-143\end{array}$ & $\begin{array}{c}5 \\
W M-62-114\end{array}$ & $\begin{array}{c}6 \\
\text { WM- } 62-116\end{array}$ & $\begin{array}{c}7 \\
\text { WM- } 64-896 C\end{array}$ & $\begin{array}{c}8 \\
75-201 x\end{array}$ & $\begin{array}{c}9 \\
78-496\end{array}$ & $\begin{array}{c}10 \\
78 A-498 A\end{array}$ \\
\hline \multicolumn{11}{|c|}{ Chemical Composition } \\
\hline $\mathrm{SiO}_{2}$ & 59.57 & 59.50 & 57.71 & 59.80 & 55.95 & 51.70 & 57.77 & 46.9 & 43.0 & 37.7 \\
\hline $\mathrm{Al}_{2} \mathrm{O}_{3}$ & 20.04 & 18.64 & 19.18 & 18.64 & 21.43 & 21.41 & 21.29 & 16.2 & 16.5 & 11.3 \\
\hline $\mathrm{Fe}_{2} \mathrm{O}_{3}$ & 1.41 & 1.65 & 1.86 & 1.46 & 1.28 & 2.31 & 2.33 & 4.7 & 3.1 & 6.2 \\
\hline $\mathrm{FeO}$ & 1.80 & 1.80 & 2.09 & 1.93 & 2.09 & 2.34 & 1.73 & 4.7 & 7.4 & 10.6 \\
\hline $\mathrm{MgO}$ & .96 & 1.09 & 1.28 & 1.11 & .69 & .67 & .37 & 3.5 & 5.6 & 7.3 \\
\hline $\mathrm{CaO}$ & 2.69 & 2.55 & 3.34 & 2.34 & 2.49 & 3.39 & 1.63 & 9.9 & 9.6 & 12.5 \\
\hline $\mathrm{Na}_{2} \mathrm{O}$ & 5.98 & 5.37 & 5.39 & 5.82 & 7.36 & 7.65 & 7.46 & 6.7 & 5.4 & 2.4 \\
\hline $\mathrm{K}_{2} \mathrm{O}$ & 5.25 & 6.60 & 5.64 & 5.91 & 6.32 & 6.54 & 5.21 & 3.6 & 3.6 & 3.8 \\
\hline $\mathrm{H}_{2} \mathrm{O}$ & .64 & .54 & .57 & .76 & .67 & 1.11 & .81 & 1.04 & 1.18 & 2.04 \\
\hline $\mathrm{TiO}_{2}$ & .86 & .92 & 1.15 & .88 & .56 & .94 & .58 & 2.1 & 2.7 & 3.4 \\
\hline $\mathrm{P}_{2} \mathrm{O}_{5}$ & .32 & .41 & .50 & .31 & .18 & .19 & .06 & 1.2 & 1.2 & 2.2 \\
\hline $\mathrm{MnO}$ & .08 & .11 & .10 & .12 & .11 & .16 & .24 & .23 & .23 & .31 \\
\hline $\mathrm{Co}_{2}$ & .07 & .43 & .45 & .50 & .24 & 1.11 & .31 & .02 & .05 & .02 \\
\hline $\mathrm{Cl}$ & .02 & .01 & .02 & .01 & .21 & .02 & .12 & -- & -- & -- \\
\hline $\mathrm{F}$ & .10 & .15 & .14 & .15 & .10 & .09 & .06 & -- & -- & -- \\
\hline Total-- & 99.79 & 99.77 & 99.42 & 99.74 & 99.68 & 99.63 & 99.97 & 100.8 & 99.6 & 99.8 \\
\hline \multicolumn{11}{|c|}{ Normative Composition } \\
\hline C & 0.78 & 0.32 & 0.66 & 0.66 & -- & --- & 1.60 & $\cdots$ & -- & -- \\
\hline $0 r$ & 31.09 & 39.09 & 33.52 & 35.02 & 37.47 & 38.79 & 30.81 & 21.1 & 17.2 & -- \\
\hline$A D$ & 49.33 & 44.00 & 44.79 & 49.11 & 28.71 & 17.51 & 45.48 & 9.7 & -- & $-\cdots$ \\
\hline An & 10.31 & 6.44 & 9.82 & 5.54 & 7.62 & 4.86 & 5.34 & 3.5 & 10.2 & 8.9 \\
\hline $\mathrm{Ne}$ & .66 & .80 & .51 & .10 & 17.45 & 25.63 & 9.11 & 25.2 & 24.9 & 11.0 \\
\hline $\mathrm{HI}$ & .03 & .02 & .03 & .02 & .35 & .03 & .20 & --- & -- & -- \\
\hline Lc & -- & -. & -- & $\ldots$ &.-- & -- & $\cdots$ & $\ldots$ & 3.3 & 17.6 \\
\hline Wo & --- & -- & -- & $-\cdots$ & .61 & 1.33 & --- & 15.6 & 12.3 & 15.1 \\
\hline En & --- & -- & --- & -- & .27 & .76 & --- & 8.6 & 7.7 & 9.4 \\
\hline Fs & $\cdots$ & $\cdots$ & $-\cdots$ & --- & .33 & .52 & -- & 1.7 & 3.9 & 4.8 \\
\hline Fo & 1.68 & 1.91 & 2.25 & 1.94 & 1.02 & .64 & .65 & --- & 4.4 & 6.2 \\
\hline $\mathrm{Fa}$ & .67 & .49 & .46 & .86 & 1.34 & .48 & .57 & -- & 2.4 & 3.5 \\
\hline $\mathrm{Cs}$ & $\cdots$ & -- &.- & -- & -- & -- & $\ldots$ &.- & $\ldots$ & .8 \\
\hline$M t$ & 2.05 & 2.40 & 2.71 & 2.12 & 1.86 & 3.36 & 3.38 & 6.8 & 4.5 & 9.0 \\
\hline 11 & 1.64 & 1.75 & 2.20 & 1.68 & 1.07 & 1.79 & 1.10 & 4.0 & 5.2 & 6.5 \\
\hline$A p$ & .76 & .97 & 1.19 & .74 & .43 & .45 & .14 & 2.8 & 2.9 & 5.2 \\
\hline $\mathrm{Fr}$ & .15 & .23 & .20 & .25 & .17 & .15 & .11 & --- & --- & -- \\
\hline $\mathrm{Cc}$ & .16 & .98 & 1.03 & 1.14 & .55 & 2.53 & .71 & .05 & .1 & .05 \\
\hline Di & $\ldots$ & -.. & $\ldots$ & -. & 1.21 & 2.61 & -.- & 21.8 & 23.8 & 29.3 \\
\hline $\mathrm{Hy}$ & $-\cdots$ & -- & -- & -- & -- & -- & -- & 4.1 & -- & -- \\
\hline 01 & 2.35 & 2.39 & 2.70 & 2.80 & 2.36 & 1.12 & 1.22 & $\ldots$ & 6.9 & 9.7 \\
\hline
\end{tabular}

*Analysis Nos, are:

1. Hornblende-biotite syenite.

2. Hornblende-biotite syenite.

3. Hornblende-biotite syenite.

4. Hornblende-biotite syenite.

5. Nepheline syenite.

6. Nepheline syenite.

7. Nepheline syenite.

8. Mafic nepheline-clinopyroxene rock.

9. Mafic nepheline-clinopyroxene rock.

10. Mafic nepheline-clinopyroxene rock. 
TABLE 5.-Chemical and normative data of quartz syenites from the complex at Democrat Creek and nepheline syenite pegmatite from the Gem Park Complex, south-central Colorado

[Values in weight percent. Leaders (--) indicate no data. Analysis 1-7 by Z. A. Hamlin and F. Brown]

\begin{tabular}{|c|c|c|c|c|c|c|c|c|}
\hline $\begin{array}{l}\text { Analysis No.* } \\
\text { Field No. }\end{array}$ & $\begin{array}{c}1 \\
75 A-363\end{array}$ & $\begin{array}{c}2 \\
75 A-369\end{array}$ & $\begin{array}{c}3 \\
75 A-373\end{array}$ & $\begin{array}{c}4 \\
75 A-381\end{array}$ & $\begin{array}{c}5 \\
75 A-382\end{array}$ & $\begin{array}{c}6 \\
75 A-383\end{array}$ & $\begin{array}{c}7 \\
75 A-385\end{array}$ & $\begin{array}{c}8 \\
G P-4\end{array}$ \\
\hline \multicolumn{9}{|c|}{ Chemical Composition } \\
\hline $\mathrm{SiO}_{2}$ & 67.7 & 74.3 & 66.8 & 74.9 & 64.1 & 68.8 & 64.3 & 59.47 \\
\hline $\mathrm{Al}_{2} \mathrm{O}_{3}$ & 15.4 & 13.4 & 15.7 & 12.7 & 16.8 & 16.0 & 16.6 & 20.53 \\
\hline $\mathrm{Fe}_{2} \mathrm{O}_{3}$ & 1.3 & .88 & 1.6 & 1.0 & 1.4 & .93 & 1.2 & $2.86 * *$ \\
\hline $\mathrm{Fe} 0$ & 2.2 & .72 & 1.9 & .28 & 3.1 & .92 & 2.5 & -- \\
\hline $\mathrm{MgO}$ & .12 & .01 & .01 & .01 & .16 & .01 & .11 & .15 \\
\hline $\mathrm{CaO}$ & .47 & .39 & .52 & .25 & 1.1 & .39 & 1.1 & .97 \\
\hline $\mathrm{Na}_{2} \mathrm{O}$ & 6.8 & 5.1 & 6.8 & 4.8 & 6.7 & 6.6 & 6.8 & 8.11 \\
\hline $\mathrm{K}_{2} \mathrm{O}$ & 4.9 & 4.2 & 4.7 & 4.1 & 5.3 & 4.8 & 5.3 & 8.97 \\
\hline $\mathrm{H}_{2} \mathrm{O}$ & .52 & .28 & .41 & .47 & .59 & .45 & .61 & --- \\
\hline $\mathrm{TiO}_{2}$ & .08 & .03 & .12 & .02 & .25 & .02 & .22 & 3.25 \\
\hline $\mathrm{P}_{2} \mathrm{O}_{5}$ & .03 & .02 & .04 & .02 & .06 & .03 & .06 & $\cdots$ \\
\hline Mn 0 & .12 & .03 & .12 & .02 & .12 & .06 & .12 & .05 \\
\hline $\mathrm{CO}_{2}$ & --- & -- & .02 & .12 & -- & $\ldots$ & .16 & --- \\
\hline $\mathrm{Cl}$ & -- & -- & .01 & .02 & .03 & .02 & .01 & -- \\
\hline$F$ & .25 & .36 & .37 & .1 & .08 & .15 & .14 & -- \\
\hline Total-- & 99.9 & 99.7 & 99.1 & 98.8 & 99.8 & 99.2 & 99.2 & 104.36 \\
\hline \multicolumn{9}{|c|}{ Normative Composition } \\
\hline$Q$ & 9.0 & 28.5 & 8.6 & 31.6 & 1.8 & 11.6 & 2.3 & -- \\
\hline or & 29.0 & 25.0 & 27.8 & 24.5 & 31.4 & 28.6 & 31.6 & 52.99 \\
\hline $\mathrm{Ab}$ & 52.0 & 43.0 & 57.7 & 40.9 & 56.6 & 56.0 & 56.3 & 19.93 \\
\hline An & --- & -- & -- & --- & .2 & --- & -- & --- \\
\hline $\mathrm{Ne}$ & $\cdots$ & -- & -.- & -- & --- & -- & --- & 19.32 \\
\hline H1 & -- & --- & -.- & --- & .05 & .03 & .02 & -- \\
\hline Ac & 3.8 & -.. & --- & --- & -- & .1 & 1.4 & -- \\
\hline Ns & .3 & -.- & -- & -.- & -- & $\cdots$ & -- & 3.00 \\
\hline Wo & .1 & -- & +- &.-- & 1.8 & .3 & 1.3 & 1.05 \\
\hline En & .3 & .02 & .01 & .02 & .4 & .02 & .3 & .87 \\
\hline Fs & 4.1 & .5 & 2.3 & .3 & 4.4 & 1.0 & 3.9 &.- \\
\hline Mt & -- & 1.4 & 2.3 & 1.4 & 2.0 & 1.3 & 1.0 & -- \\
\hline II & .15 & .06 & .2 & .05 & .5 & .04 & .4 & 5.54 \\
\hline$F$ & $\cdots$ & .1 & .04 & .4 & $\cdots$ &.- & $\cdots$ & $\cdots$ \\
\hline $\mathrm{Ap}$ & .07 & .03 & .1 & .03 & .1 & .07 & .1 &.- \\
\hline $\mathrm{Fr}$ & .51 & .7 & .7 & .2 & .2 & .3 & .3 & $-\cdots$ \\
\hline $\mathrm{Pf}$ & --- & -- & -- & --- & -- & --. & -- & .56 \\
\hline$D i$ & .29 & --- & -.- & -.. & 3.8 & .6 & 2.7 & .87 \\
\hline $\mathrm{Hy}$ & 4.28 & .6 & 2.3 & .3 & 2.8 & .8 & 2.7 & 1.05 \\
\hline 01 & --- & --- & --- & --- & --- & -- & --- & $\ldots$ \\
\hline
\end{tabular}

*Analysis Nos. are:

1. Quartz syenite.

2. Quartz syenite.

3. Quartz syenite.

4. Quartz syenite.

5. Quartz syenite.

6. Quartz syenite.

7. Quartz syenite.

8. Nepheline syenite pegmatite (Roden, 1977, table 1).

$\star \star T o t a l$ iron as $\mathrm{Fe}_{2} \mathrm{O}_{3}$. 

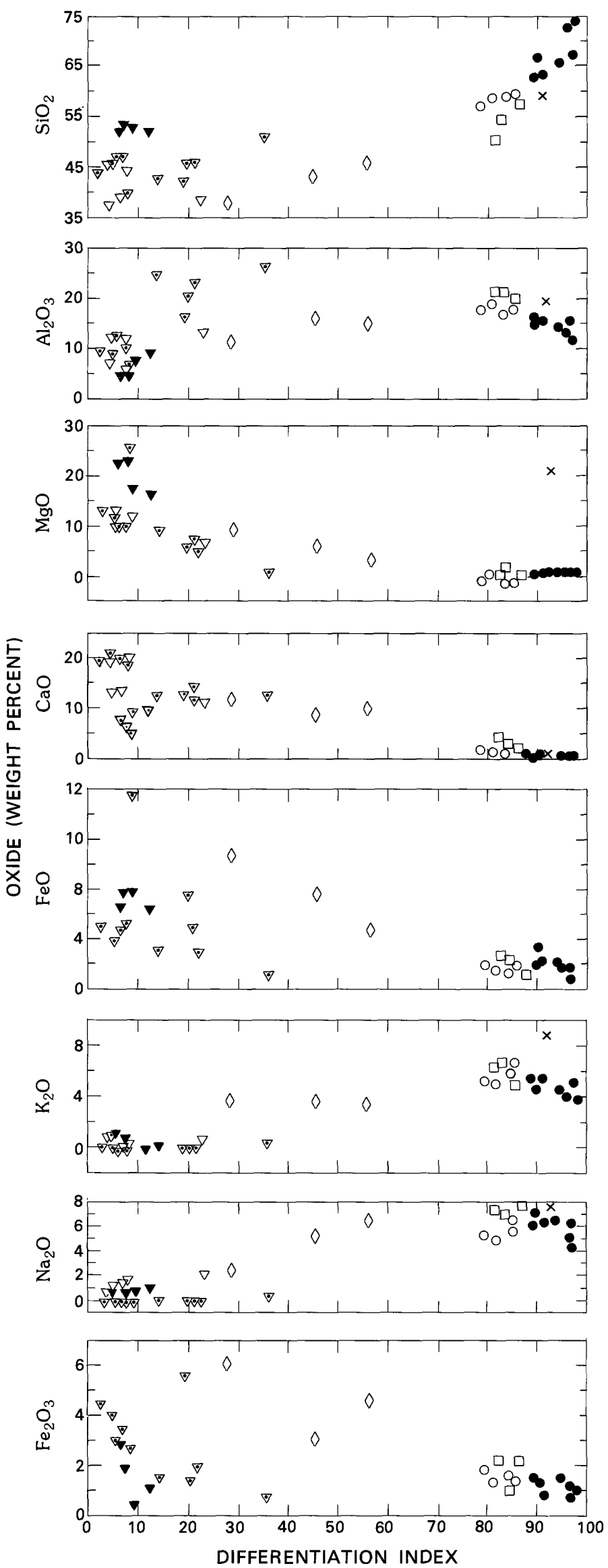

that the compositions of the rocks in the complexes are typically bimodal, with the exception of the mafic nepheline-clinopyroxene rocks. This bimodality is characteristic of rock sequences that form as a result of liquid immiscibility, although other evidence of this origin, such as the presence of ocellate structures, has not been recognized.

\section{MINOR ELEMENTS \\ MAFIC-ULTRAMAFIC ROCKS}

A summary of minor-element contents of maficultramafic rocks from the three alkaline complexes is presented in tables 6 and 7 . Nine analyses from the Iron Mountain part of the McClure Mountain Complex (Shawe and Parker, 1967, table 3) are included in the summary.

Abundances of elements in Wet Mountains maficultramafic rocks, alkaline ultramafic rocks of the Kola Peninsula (Gerasimovsky, 1974, table 3), and "average" ultramafic rocks (Goles, 1967, table 11.1) are compared with the abundance of elements in igneous rocks of the upper continental crust (Wedepohl, 1971) in table 8. The alkaline rocks of the Kola Peninsula are more alkaline than are Wet Mountains pyroxenitic rocks, and the "average" ultramafic rock is derived chiefly from tholeiitic rocks.

Alkaline ultramafic rocks from the Kola Peninsula contain amounts of $\mathrm{Ba}, \mathrm{Be}, \mathrm{Nb}, \mathrm{Sc}, \mathrm{Sr}, \mathrm{V}, \mathrm{Zr}, \mathrm{Ga}, \mathrm{U}$, Th, and other elements greater than the amounts in average igneous rocks in the Earth's crust; $\mathrm{Cr}, \mathrm{Co}, \mathrm{Ni}$, $\mathrm{Cu}, \mathrm{Pb}$, and other elements occur in amounts less than, or nearly equal to, those in average crustal rocks. The "average" ultramafic rock (Goles, 1967), on the other hand, contains abundant $\mathrm{Co}, \mathrm{Cr}$, and $\mathrm{Ni}$, and low con-

\section{EXPLANATION}

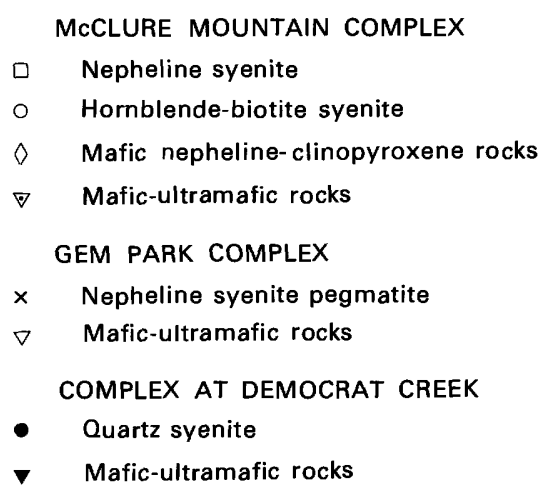

FIGURE 25.-Plots of differentiation index (DI) versus oxide weight percent of rocks from the McClure Mountain Complex, Gem Park Complex, and complex at Democrat Creek. $\mathrm{DI}=\mathbf{\Sigma}(\mathrm{Q}+\mathrm{Or}+\mathrm{Ab}+\mathrm{Ne}$ $+\mathrm{Lc})$. 
TABLE 6.-Summary of minor-element analyses of samples from the McClure Mountain Complex, south-central Colorado

[Values in parts per million; $n$, number of samples; Leaders (---) indicate no data]

\begin{tabular}{|c|c|c|c|c|c|c|c|c|}
\hline & \multicolumn{2}{|c|}{$\begin{array}{l}\text { Hornblende-biotite } \\
\text { syenite, } n=44\end{array}$} & \multicolumn{2}{|c|}{$\begin{array}{l}\text { Nepheline syenite, } \\
n=11\end{array}$} & \multicolumn{2}{|c|}{$\begin{array}{l}\text { Nephel ine-cl inopyroxene } \\
\text { rocks, } n=8\end{array}$} & \multicolumn{2}{|c|}{$\begin{array}{l}\text { Mafic-ultramafic } \\
\text { rocks, } n=20\end{array}$} \\
\hline & Mean & Range & Mean & Range & Mean & Range & Mean & Range \\
\hline $\mathrm{Ba}$ & 2527 & $200-7000$ & 2479 & $70-5000$ & 1320 & $300-3000$ & 111 & $30-200$ \\
\hline $\mathrm{Be}$ & $<1.5$ & $<1.5-2$ & $<1.5$ & $<1.5-2$ & $<1.5$ & $<1.5-5.1$ & $<1.5$ & -.. \\
\hline Co & $<5$ & $<5-15$ & 8.5 & $<5-20$ & 27 & $15-50$ & 42 & $5-150$ \\
\hline $\mathrm{Cr}$ & $<1$ & $<1-50$ & 15 & $<1-150$ & 167 & $2-700$ & 285 & $2-1000$ \\
\hline $\mathrm{Cu}$ & 4.3 & $<1-30$ & 11 & $1-50$ & 32 & $7-50$ & 77 & $3-200$ \\
\hline $\mathrm{La}$ & 78 & $<50-150$ & 108 & $50-200$ & 142 & $100-200$ & $<30$ & $<30-30$ \\
\hline Mo & $<3$ & --- & $<3$ & $<3-5$ & $<3$ & --- & $<3$ & --- \\
\hline $\mathrm{Nb}$ & 46 & $10-150$ & 88 & $20-300$ & 112 & $70-220$ & $<10$ & $<10-10$ \\
\hline $\mathrm{Ni}$ & $<3$ & $<3-30$ & 8 & $<3-50$ & 65 & $7-150$ & 128 & $<5-500$ \\
\hline $\mathrm{Pb}$ & $<10$ & $<10-20$ & 11 & $<10-30$ & $<10$ & $<10-10$ & $<10$ & --- \\
\hline Sc & $<5$ & $<5-10$ & $<5$ & $<5-15$ & 13 & $7-30$ & 43 & $5-100$ \\
\hline $\mathrm{Sr}$ & 1559 & $50-7000$ & 2900 & $200-7000$ & 1712 & $700-3000$ & 844 & $50-3000$ \\
\hline v & 50 & $<10-200$ & 103 & $<7-300$ & 258 & $150-500$ & 256 & $30-700$ \\
\hline Y & 22 & $10-70$ & 29 & $10-70$ & 53 & $30-100$ & 12 & $<10-20$ \\
\hline $\mathrm{Zr}$ & 158 & $10-1000$ & 165 & $70-300$ & 219 & $150-390$ & 18 & $<10-70$ \\
\hline $\mathrm{Ce}$ & $<100$ & $<100-200$ & 155 & $<150-500$ & 188 & $<100-380$ & $<100$ & $\cdots$ \\
\hline $\mathrm{Ga}$ & 20 & $15-30$ & 24 & $15-30$ & 24 & $20-30$ & 14 & $7-20$ \\
\hline$Y b$ & 2.2 & $<1-10$ & 2.8 & $1.5-7$ & 5 & $3-9.6$ & $<1$ & $<1-2$ \\
\hline Nd & $<70$ & $<70-150$ & 84 & $<70-150$ & 114 & $<70-200$ & $<70$ & $\cdots$ \\
\hline U & 2.44 & $0.53-7.06$ & 4.01 & $0.9-22.4$ & 1.4 & $0.9-2.2$ & 0.2 & $<0.2-0.5$ \\
\hline Th & 9.04 & $<2.3-23.4$ & 6.9 & $4.0-11.7$ & 8.4 & $6.4-13.4$ & .7 & $<.1-1.4$ \\
\hline
\end{tabular}

centrations of trace elements characteristic of syenitic and granitic rocks.

The mafic-ultramafic rocks from the complex at Democrat Creek (table 7) contain average amounts of $\mathrm{Co}, \mathrm{Cr}, \mathrm{Cu}, \mathrm{Ni}$, and $\mathrm{Sc}$ greater than those in average crustal rocks, and amounts of $\mathrm{Ba}, \mathrm{Sr}, \mathrm{Y}, \mathrm{Zr}, \mathrm{Ga}, \mathrm{RaeU}$, and Th less than those in average crustal rocks. Thus, these rocks have minor-element signatures more similar to the "average" ultramafic rocks derived from tholeitic rocks (table 8).

Mafic-ultramafic rocks from the Gem Park Complex (table 7) contain amounts of $\mathrm{Ba}, \mathrm{Co}, \mathrm{Cr}, \mathrm{Cu}, \mathrm{Ni}, \mathrm{Sc}$, $\mathrm{Sr}, \mathrm{V}$, and Ga greater than those in average crustal rocks, and amounts of $\mathrm{Y}, \mathrm{Zr}, \mathrm{RaeU}$, and Th less than those in average crustal rocks. This suite of minor elements is partly characteristic of the "average" ultramafic rock (table 8) and partly characteristic of Kola Peninsula alkaline ultramafic rocks (table 8 ).

Mafic-ultramafic rocks from the McClure Mountain
Complex (table 6) contain amounts of $\mathrm{Co}, \mathrm{Cr}, \mathrm{Cu}, \mathrm{Ni}$, $\mathrm{Sc}, \mathrm{Sr}$, and V greater than those in average crustal rocks, and amounts of $\mathrm{Ba}, \mathrm{Y}, \mathrm{Zr}, \mathrm{RaeU}$, and Th less than those in average crustal rocks. Except for barium, these minor-element signatures are similar to those of mafic-ultramafic rocks of the Gem Park Complex (table 7).

These comparisons suggest that the mafic-ultramafic rocks from the complex at Democrat Creek have minorelement abundances more similar to tholeiitic rocks than to alkaline rocks. The mafic-ultramafic rocks from the McClure Mountain and Gem Park Complexes have minor-element abundances similar to each other, but the minor elements have characteristics of both alkaline and tholeiitic ultramafic rocks.

\section{LEUCOCRATIC ROCKS}

A summary of minor-element analyses of quartz syenites from the complex at Democrat Creek is given in 
TABLE 7.-Summary of minor-element analyses of samples from the complex at Democrat Creek and the Gem Park Complex, south-central Colorado

Values in parts per million; $n$, number of samples; leaders (---) indicate no data]

\begin{tabular}{|c|c|c|c|c|c|c|}
\hline & \multicolumn{4}{|c|}{ Complex at Democrat Creek } & \multirow{2}{*}{\multicolumn{2}{|c|}{$\begin{array}{l}\text { Gem Park Complex } \\
\begin{array}{l}\text { Mafic-ul tramafic } \\
\text { rocks, } n=7\end{array}\end{array}$}} \\
\hline & \multicolumn{2}{|c|}{$\begin{array}{l}\text { Quartz syenite, } \\
n=21\end{array}$} & \multicolumn{2}{|c|}{$\begin{array}{l}\text { Mafic-ultramafic } \\
\text { rocks, } n=4\end{array}$} & & \\
\hline & Mean & Range & Mean & Range & Mean & Range \\
\hline $\mathrm{Ba}$ & 320 & $50-2000$ & 72 & $50-100$ & 657 & $100-1500$ \\
\hline Be & 15 & $5-50$ & $<1.5$ & -- & $<1.5$ & --- \\
\hline Co & $<5$ & $\cdots$ & 50 & $30-70$ & 73 & $50-100$ \\
\hline $\mathrm{Cr}$ & $<1$ & $<1-2$ & 1675 & $700-3000$ & 404 & $1-1000$ \\
\hline $\mathrm{Cu}$ & 8 & $<1-70$ & 175 & $150-200$ & 143 & $20-500$ \\
\hline La & 244 & $<30-500$ & $<30$ & --- & $<30$ & $<30-30$ \\
\hline Mo & $<3$ & $<3-5$ & $<3$ & $<3-7$ & $<3$ & -- \\
\hline $\mathrm{Nb}$ & 340 & $70-1000$ & $<10$ & $\cdots$ & $<10$ & $<10-10$ \\
\hline $\mathrm{Ni}$ & $<5$ & --- & 412 & $150-700$ & 152 & $5-200$ \\
\hline $\mathrm{Pb}$ & 40 & $<10-300$ & $<10$ & -- & $<10$ & --- \\
\hline Sc & $<3$ & $<3-7$ & 45 & $30-70$ & 49 & $20-70$ \\
\hline $\mathrm{Sr}$ & 30 & $10-100$ & 135 & $70-200$ & 757 & $300-2000$ \\
\hline v & $<5$ & $<5-10$ & 110 & $70-150$ & 586 & $<7-1000$ \\
\hline Y & 95 & $30-150$ & 10 & $<10-20$ & 26 & $20-50$ \\
\hline $\mathrm{Zr}$ & 785 & $200-2000$ & 16 & $<10-30$ & 98 & $50-150$ \\
\hline $\mathrm{Ce}$ & 384 & $<100-700$ & $<100$ & -- & $<100$ & --- \\
\hline Ga & 72 & $50-100$ & 7 & $<5-10$ & 28 & $15-50$ \\
\hline Yb & 12 & $3-20$ & 1.2 & $<1-2$ & $<1$ & --- \\
\hline Nd & 133 & $<70-200$ & --- & --- & $<70$ & $<70-70$ \\
\hline U & 11.8 & $3-22$ & 0.2 & --- & 0.4 & $0.2-0.62$ \\
\hline Th & 78.3 & $50-105$ & 0.5 &.-- & 2.4 & $1.0-3.7$ \\
\hline
\end{tabular}

table 7. A similar summary for hornblende-biotite syenites and nepheline syenites from the McClure Mountain Complex is given in table 6. Abundance of elements in alkali syenite and miaskitic nepheline syenite (Lazarenkov, 1978) and average crustal abundance of certain elements (Wedepohl, 1971) are given in table 8.

The quartz syenites of the complex at Democrat Creek contain average amounts of $\mathrm{Be}, \mathrm{La}, \mathrm{Nb}, \mathrm{Pb}, \mathrm{Y}$, $\mathrm{Zr}, \mathrm{Ce}, \mathrm{Ga}, \mathrm{Yb}, \mathrm{Nd}, \mathrm{RaeU}$, and Th greater than crustal abundances, and amounts of $\mathrm{Ba}, \mathrm{Co}, \mathrm{Cr}, \mathrm{Cu}, \mathrm{Ni}, \mathrm{Sc}$, $\mathrm{Sr}$, and $\mathrm{V}$ less than crustal abundances. Hornblendebiotite syenites from the McClure Mountain Complex contain average amounts of $\mathrm{Ba}, \mathrm{La}, \mathrm{Nb}$, and $\mathrm{Sr}$ greater than crustal abundances and amounts of $\mathrm{Co}, \mathrm{Cr}, \mathrm{Cu}$,
$\mathrm{Ni}, \mathrm{Sc}, \mathrm{V}, \mathrm{Y}, \mathrm{Zr}$, RaeU, and Th less than crustal abundances. The nepheline syenites from the McClure Mountain Complex contain average amounts of $\mathrm{Ba}$, $\mathrm{La}$, $\mathrm{Nb}, \mathrm{Sr}, \mathrm{Ce}, \mathrm{Ga}$, and $\mathrm{Nd}$ greater than crustal abundances, and amounts of $\mathrm{Cr}, \mathrm{Cu}, \mathrm{Ni}, \mathrm{Sc}, \mathrm{RaeU}$, and $\mathrm{Th}$ less than crustal abundances; some elements occur in amounts similar to crustal abundances.

Considerable differences exist in the average content of minor elements in the syenites from Democrat Creek and McClure Mountain. The quartz syenites from the complex at Democrat Creek contain greater average amounts of $\mathrm{Be}, \mathrm{La}, \mathrm{Nb}, \mathrm{Pb}, \mathrm{Y}, \mathrm{Zr}, \mathrm{Ce}, \mathrm{Ga}, \mathrm{Yb}, \mathrm{Nd}$, $\mathrm{RaeU}$, and Th than do the syenites from the McClure Mountain Complex. According to Gerasimovsky (1974, p. 406), all these elements, excluding lead, are charac- 
TABLE 8.-Abundance of elements in several types of rocks

[Values in parts per million. Leaders (---) indicate no data]

\begin{tabular}{|c|c|c|c|c|c|}
\hline Analysis No.* & 1 & 2 & 3 & 4 & 5 \\
\hline $\mathrm{Ba}$ & 590 & 1567 & 1388 & 850 & 0.4 \\
\hline $\mathrm{Be}$ & 2 & --- & $\cdots$ & 7.4 & .2 \\
\hline Co & 12 & 14 & 9.3 & 15 & 110 \\
\hline $\mathrm{Cr}$ & 70 & 11 & 16 & 30 & 2400 \\
\hline $\mathrm{Cu}$ & 30 & 28 & 23 & 34 & 30 \\
\hline La & 44 & 146 & 134 & $\cdots$ & $\cdots$ \\
\hline Mo & 1 & -.. & $\ldots$ & -- & .2 \\
\hline $\mathrm{Nb}$ & 20 & 70 & 89 & 300 & --- \\
\hline $\mathrm{Ni}$ & 44 & 6.9 & 10 & 36 & 1500 \\
\hline $\mathrm{Pb}$ & 15 & 25 & 35 & 13 & .05 \\
\hline $\mathrm{Sc}$ & 14 & --- & --- & 24 & 16 \\
\hline $\mathrm{Sr}$ & 290 & 434 & 835 & 1300 & 20 \\
\hline$v$ & 95 & 26 & 52 & 440 & 40 \\
\hline$Y$ & 34 & 64 & 62 & --- & 5 \\
\hline $\mathrm{Zr}$ & 160 & 510 & 411 & 340 & $30-45$ \\
\hline $\mathrm{Ce}$ & 75 & -- & --- & --- & --- \\
\hline $\mathrm{Ga}$ & 17 & 27 & 30 & 26 & 5 \\
\hline Yb & 3.4 & $\cdots$ & $\cdots$ & -- & $\cdots$ \\
\hline $\mathrm{Nd}$ & 30 & -- & --- & -- & -- \\
\hline$U$ & 3.5 & 4.5 & 4.8 & 15 & .02 \\
\hline$T h$ & 11 & 20 & 13.2 & 90 & .06 \\
\hline
\end{tabular}

*Analysis Nos. are:

1. Abundance of elements in igneous rocks of the upper continental crust (Wedepoh1, 1971, table 7.3).

2. Alkali syenite (Lazarenkov, 1978, table 1).

3. Miaskitic nepheline syenite (Lazarenkov, 1978, table 1).

4. Alkaline ultramafic rocks, Kola Peninsula.

(Gerasimovsky, 1974, table 3).

5. "Average" ultranafic rock (Goles, 1967, table 11.1).

teristic of agpaitic nepheline syenites, which by definition (Sorensen, $1974 \mathrm{~b}$, p. 23) have the ratio $\left(\mathrm{Na}_{2} \mathrm{O}+\mathrm{K}_{2} \mathrm{O}\right) / \mathrm{Al}_{2} \mathrm{O}_{3}$ (molecular proportions) greater than one. This agpaitic index (see fig. 24) averages 1.007 for the seven chemical analyses of quartz syenite in table 5 , but the quartz syenites possess few additional characteristics of agpaitic nepheline syenites (Sorensen, 1974b, p. 24). The quartz syenites also contain less average amounts of $\mathrm{Ba}, \mathrm{Co}, \mathrm{Cr}, \mathrm{Ni}, \mathrm{Sr}$, and $\mathrm{V}$ than do the nepheline syenites. These elements, except barium and strontium, chiefly reside in the mafic mineral assemblage; the paucity of mafic minerals in the quartz syenites reflects this characteristic. The paucity of barium and strontium is usually a function of crystallization and removal of feldspar from the mag- matic system. This deficiency, especially of strontium, in the quartz syenites relative to barium and strontium in the associated mafic-ultramafic rocks is perplexing, and may suggest a low concentration of strontium and probably barium in the crystallizing magma.

The quartz syenites at Democrat Creek contain high average abundances of uranium and thorium. Eighteen samples contain $12.9 \mathrm{ppm} \mathrm{RaeU}\left(15 \mathrm{ppm} \mathrm{U}_{3} \mathrm{O}_{8}\right)$ and 80.4 ppm thorium (91 ppm $\mathrm{ThO}_{2}$ ). For comparison, the Mesozoic Conway Granite of New Hampshire contains similar abundances of uranium ( $15 \mathrm{ppm} \mathrm{U}_{3} \mathrm{O}_{8}$ ), but somewhat less thorium $\left(64 \mathrm{ppm} \mathrm{ThO}_{2}\right)$.

\section{MAFIC NEPHELINE-CLINOPYROXENE ROCKS}

The average composition of eight samples of mafic nepheline-clinopyroxene rocks is given in table 5 . These rocks contain average amounts of $\mathrm{Ba}, \mathrm{Co}, \mathrm{Cr}, \mathrm{La}, \mathrm{Nb}$. $\mathrm{Sr}, \mathrm{V}, \mathrm{Y}, \mathrm{Zr}, \mathrm{Ce}, \mathrm{Yb}$, and Nd greater than crustal abundance, and average amounts of lead less than crustal abundance (table 8). $\mathrm{Be}, \mathrm{Cu}, \mathrm{Ni}, \mathrm{Sc}$, and $\mathrm{Ga}$ occur in amounts similar to crustal abundance. These rocks possess minor-element signatures similar to those of alkaline ultramafic rocks of the Kola Peninsula (table 8).

\section{RUBIDIUM-STRONTIUM SYSTEMATICS AND RARE-EARTH-ELEMENT DISTRIBUTION PATTERNS}

Concentrations of rubidium, strontium, rare-earth elements, and strontium isotopes have been determined in several alkaline rocks by C. E. Hedge and reported in Armbrustmacher, Hedge, and Parker (1979) and in Armbrustmacher and Hedge (1982). These values are given in tables 9 and 10 .

\section{RARE-EARTH ELEMENTS}

Chondrite-normalized rare-earth-element (REE) data for mafic rocks from the complex at Democrat Creek and the McClure Mountain Complex are plotted on figure 26, along with data from Kay and Gast (1973) for tholeiitic mid-ocean-ridge basalt, alkali basalt, and nephelinite. The gabbroic rock from Democrat Creek contains less total REE than do the several types of basalts, and it shows some increase in the light- to heavy-REE ratio relative to amounts of REE in the tholeiitic basalt. The mafic cumulate rocks from the McClure Mountain Complex contain total amounts of REE comparable to those in tholeiitic basalt, but the light REE are enriched and the heavy REE depleted relative to the tholeiitic basalt. Total REE content of cumulus rocks from the McClure Mountain Complex is greater than that in the Democrat Creek mafic rock; however, the McClure Mountain cumulates contain less 
TABLE 9.-Rubidium and strontium content (in parts per million) and several ratios for rocks from the McClure Mountain Complex and the complex at Democrat Creek, south-central Colorado

[Analyses by C. E. Hedge; leaders (--) indicate no data]

\begin{tabular}{|c|c|c|c|c|c|c|c|}
\hline Field No. & Rock type & $\mathrm{RD}$ & $\mathrm{Sr}$ & $\mathrm{Rb} / \mathrm{Sr}$ & ${ }^{87} \mathrm{Rb} /{ }^{86} \mathrm{Sr}$ & ${ }^{87} \mathrm{Sr} /{ }^{86} \mathrm{Sr}$ & $\begin{array}{c}\text { Initial } \\
{ }^{87} \mathrm{Sr} /{ }^{86} \mathrm{Sr}\end{array}$ \\
\hline \multicolumn{8}{|c|}{ McClure Mountain Complex } \\
\hline WM-64-827 & Plagioclase-clinopyroxene cumulate & 3.17 & 1010 & 0.0031 & 0.0091 & 0.70484 & 0.70477 \\
\hline WM-64-829 & -- do-- & 1.69 & 370 & 0.0046 & 0.0132 & 0.70454 & 0.70444 \\
\hline 417 & Nephel ine syenite & 126 & 1725 & 0.0730 & 0.2113 & 0.70519 & 0.70359 \\
\hline WM-62-116 & -- do-- & 134 & 2939 & 0.0456 & 0.1318 & 0.70497 & 0.70397 \\
\hline 4 & $--\mathrm{d} 0--$ & 161 & 2266 & 0.0711 & 0.1890 & 0.70515 & 0.70372 \\
\hline 421 & --do-- & 194 & 103 & 1.883 & 5.470 & 0.74548 & -- \\
\hline WM-62-143 & Hornblende-biotite syenite & 94.6 & 542 & 0.1745 & 0.5048 & 0.70856 & 0.70475 \\
\hline 8 & --do-- & 86.9 & 487 & 0.1784 & 0.5166 & 0.70831 & 0.70441 \\
\hline 12 & -- do-- & 98.4 & 530 & 0.1857 & 0.5371 & 0.70819 & 0.70413 \\
\hline 21 & -- do-- & 92.0 & 531 & 0.1733 & 0.5019 & 0.70821 & 0.70442 \\
\hline 419 & Carbonatite & 0.3 & 4997 & 0.00006 & 0.00020 & 0.70378 & 0.70378 \\
\hline $419 x$ & -- do-- & 0.6 & 11632 & 0.00008 & 0.00016 & 0.70406 & 0.70406 \\
\hline 496 & Mafic nepheline-cl inopyroxene rock & 97.1 & 1582 & 0.0614 & 0.1775 & 0.7050 & 0.7037 \\
\hline $498 \mathrm{~A}$ & -- do-- & 78.6 & 1370 & 0.0574 & 0.1660 & 0.7051 & 0.7038 \\
\hline \multicolumn{8}{|c|}{ Complex at Democrat Creek } \\
\hline 299 & Gabbro & 5.25 & 285 & 0.0184 & 0.0535 & 0.70290 & 0.70252 \\
\hline 302 & -- do-- & 1.32 & 208 & 0.0063 & 0.0183 & 0.70309 & 0.70296 \\
\hline 359 & Pyroxenite & 3.42 & 162 & 0.0211 & 0.0609 & 0.70384 & 0.70340 \\
\hline 412 & Quartz syenite & 96.9 & 474 & 0.2044 & 0.5923 & 0.70746 & 0.70315 \\
\hline 413 & --do-- & 251 & 34.1 & 7.361 & 21.61 & 0.86059 & $-\cdots$ \\
\hline 414 & --do-- & 174 & 26.1 & 6.667 & 19.54 & 0.84414 & -- \\
\hline 363 & -- do-- & 297 & 11.0 & 27.00 & 82.47 & 1.3146 & --- \\
\hline 369 & --do-- & 233 & 10.4 & 22.40 & 67.84 & 1.1893 & -- \\
\hline 382 & --do-- & 172 & 41.9 & 4.105 & 12.00 & 0.79088 &.-- \\
\hline
\end{tabular}

abundant REE than do the alkali basalt and the nephelinite.

Using the modal analyses of the mafic-ultramafic rocks and published crystal-to-liquid distribution coefficients for the component minerals, and assuming that the rocks formed by cumulus processes, one can calculate the REE patterns for the liquids from which these mafic rocks crystallized. These patterns are shown with the REE pattern for alkali basalt on figure 27. The close similarity of these REE patterns suggests that the liquids from which the gabbro at Democrat Creek and the cumulus mafic rocks at McClure Mountain Complex crystallized are similar in REE composition to a normal alkali basalt magma. Just as the REE content of the basalts increases in the order tholeiite-alkali basalt-nephelinite (fig. 26), perhaps the liquid from which the McClure Mountain cumulates crystallized had a slightly higher alkali content than the liquid from which the gabbros at Democrat Creek crystallized; the result is the more tholeiitic composition of the Democrat Creek rocks.

Chondrite-normalized REE data for the various syenites (table 2) are plotted on the diagrams in figures 28,29 , and 30 . The REE patterns of the hornblendebiotite syenites (fig. 28) in the McClure Mountain Complex vary only slightly. This small variation correlates with their small variations in modal mineralogy, normative mineralogy, and major-element abundances. Their 
TABLE 10.-Rare-earth-element content (in parts per million) of rocks from the McClure Mountain Complex and the complex at Democrat Creek, south-central Colorado

[Analyses by C. E. Hedge; leaders (---) indicate no data]

\begin{tabular}{|c|c|c|c|c|c|c|c|c|c|}
\hline Field No. & Rock type & $\mathrm{Ce}$ & $\mathrm{Nd}$ & $\operatorname{Sin}$ & Eu & $\mathrm{Gd}$ & Dy & Er & $Y_{b}$ \\
\hline \multicolumn{10}{|c|}{ McClure Mountain Complex } \\
\hline WM-64-827 & Plagioclase-clinopyroxene cumulate & 25.0 & 15.7 & 3.71 & 1.36 & 5.28 & 2.71 & 1.20 & 0.860 \\
\hline WM-64-829 & --do-- & 12.6 & 13.0 & 3.97 & 1.36 & 5.33 & 3.57 & 1.57 & 1.06 \\
\hline 417 & Nepheline syenite & 108 & 37.8 & 5.74 & 2.34 & 4.34 & 3.52 & 1.98 & 1.90 \\
\hline WM-62-116 & -- do-- & 159 & 60.5 & 9.38 & 2.78 & 6.39 & 4.98 & 2.37 & 1.95 \\
\hline 421 & -- do-- & 104 & 32.7 & 4.58 & 0.871 & 4.02 & 2.30 & 1.32 & 1.19 \\
\hline WM-62-143 & Hornblende-biotite syenite & 119 & 46.2 & 7.29 & 2.64 & 5.37 & 3.95 & 2.25 & 1.65 \\
\hline 8 & -- do-- & -- & 50.0 & 7.95 & 2.87 & 5.93 & 4.38 & 2.05 & 1.64 \\
\hline 21 & -- do-- & 104 & 39.0 & 6.11 & 2.54 & 4.67 & 3.34 & 1.69 & 1.41 \\
\hline 419 & Carbonatite & 3308 & 1346 & 177 & 51.1 & --- & 116 & 51.3 & 38.5 \\
\hline $419 x$ & $--d o--$ & 648 & 220 & 34.9 & 10.3 & $-\cdots$ & 22.9 & 13.2 & 13.9 \\
\hline \multicolumn{10}{|c|}{ Complex at Democrat Creek } \\
\hline 299 & Gabbro & 10.8 & 6.64 & 1.71 & 0.521 & 2.03 & 1.43 & 0.787 & 0.722 \\
\hline 412 & Quartz syenite & 116 & 45.6 & 8.26 & 2.58 & 7.05 & 6.32 & 3.52 & 3.40 \\
\hline 413 & -- do-- & 470 & 122 & 18.8 & 0.966 & 17.5 & 19.4 & 12.9 & 14.1 \\
\hline
\end{tabular}

small positive europium anomalies are due to the presence of sodic plagioclase. The REE patterns of nepheline syenites (fig. 29) show small positive and negative europium anomalies, which also correlate respectively with more and less modal plagioclase. These patterns also correlate with the variability in modal mineralogy of these rocks. The REE patterns of the quartz syenites of the complex at Democrat Creek (fig. 30) vary considerably. One pattern has a fairly large negative europium anomaly that corresponds to low $\mathrm{CaO}(<1.0$ percent) and low strontium contents (34 parts per million). These data suggest that this rock crystallized from a melt from which plagioclase had been removed.

In summary, the REE data show that the Democrat Creek mafic rocks are slightly, but significantly, different from the McClure Mountain Complex cumulates. The liquids from which the Democrat Creek mafic rocks crystallized appear to have been less alkaline than the liquids from which the McClure Mountain Complex cumulates crystallized. The REE patterns for the syenites reflect the homogeneity and apparent lack of evidence of fractionation of the hornblende-biotite syenite, the variation in plagioclase content because of some fractionation in the nepheline syenites, and the strong evidence of fractionation because of loss of plagioclase in the quartz syenites at Democrat Creek.

\section{INITIAL ${ }^{87} \mathbf{S r} /{ }^{86} \mathrm{Sr}$ RATIOS}

Initial ${ }^{87} \mathrm{Sr} /{ }^{86} \mathrm{Sr}$ ratios for alkaline rocks of the Wet Mountains area range in value from 0.7025 to 0.7048 (fig. 31). Uncertainty of these ratios is less than \pm 0.0001 . Mafic-ultramafic rocks from the complex at Democrat Creek have initial values that range from 0.7025 to 0.7034 , and one sample of quartz syenite has a value of 0.7032 . Mafic-ultramafic rocks from the McClure Mountain Complex have values of 0.7044 and 0.7048 , nepheline syenites range from 0.7036 to 0.7040 , hornblende-biotite syenites range from 0.7041 to 0.7048 , mafic nepheline-clinopyroxene rocks have values of 0.7037 and 0.7038 , and six carbonatites, including four analyzed by Roden (1977), have values of 0.7036 to 0.7041. The Democrat Creek rocks appear to form a distinct group characterized by rather low initial ${ }^{87} \mathrm{Sr} /$ ${ }^{86} \mathrm{Sr}$ values. At the McClure Mountain Complex, hornblende-biotite syenite has initial ${ }^{87} \mathrm{Sr} /{ }^{86} \mathrm{Sr}$ ratios similar to those of the mafic-ultramafic cumulate rocks but different from the nepheline syenites, the mafic nepheline-clinopyroxene rocks, and the carbonatites, which constitute a separate group having similar values. The carbonatites that intrude the Gem Park Complex have ratios (Roden, 1977) similar to carbonatites that intrude the McClure Mountain Complex.

A summary of strontium isotopic contents of alkaline 


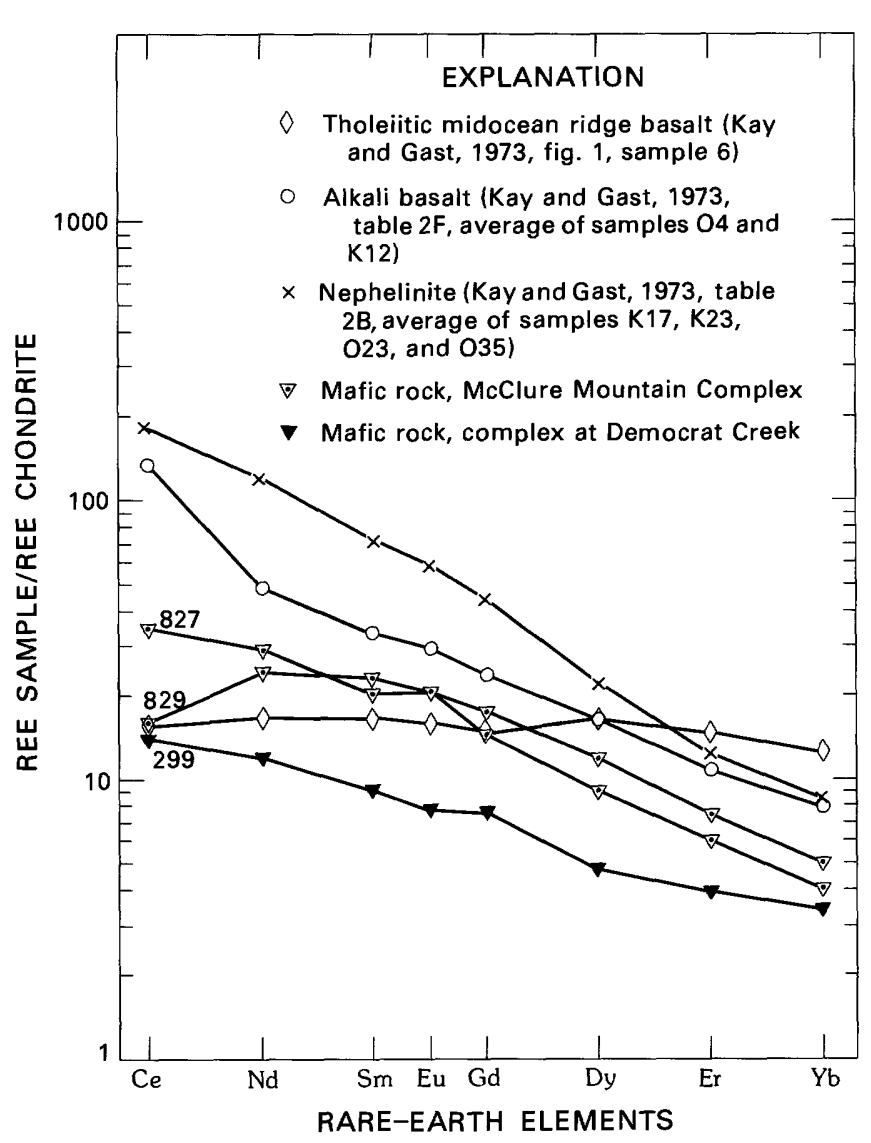

FIGURE 26.-Chondrite-normalized rare-earth-element data for mafic rocks from McClure Mountain Complex, the complex at Democrat Creek, and other basalt samples (from Kay and Gast, 1973).

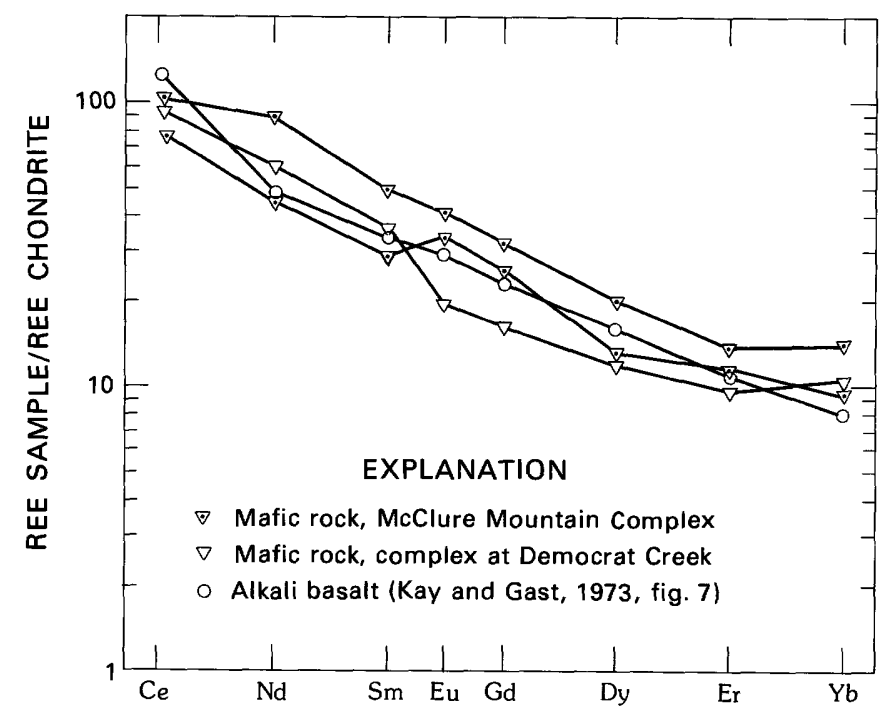

RARE EARTH ELEMENTS

FIGURE 27.-Chondrite-normalized rare-earth-element data for liquids from which mafic rocks of McClure Mountain Complex and complex at Democrat Creek crystallized. Data are calculated from published crysta//liquid distribution coefficients.

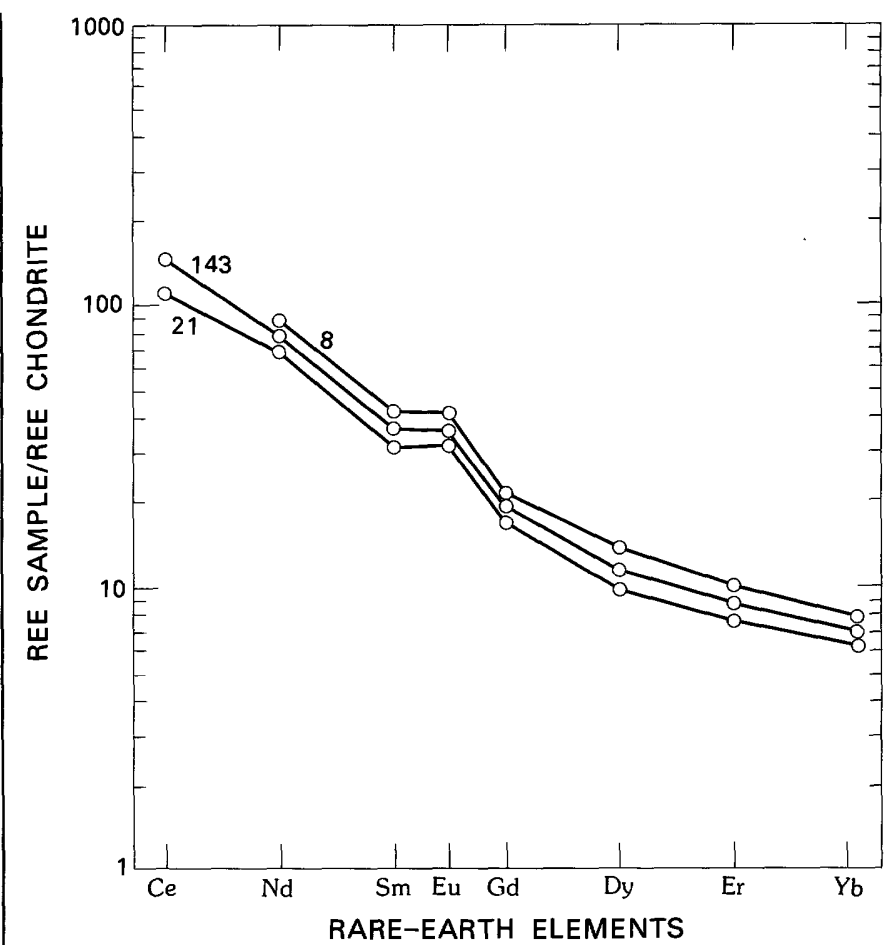

FIGURE 28.-Chondrite-normalized rare-earth-element data for hormblende-biotite syenite samples from the McClure Mountain Complex.

rocks from Australia, Spain, and the Western United States (Powell and Bell, 1970) shows initial ${ }^{87} \mathrm{Sr} /{ }^{86} \mathrm{Sr}$ ratios ranging from 0.7034 to 0.7169 ; some of the values are similar to those of oceanic basaltic rocks. But ratios for rocks from the Western United States (from 0.703 to 0.709) suggested to Powell and Bell that those rocks may have formed by partial melting of deep crustal rocks that have lower rubidium/strontium ratios than those of average crust. Bell and Powell (1970) showed a range of initial ${ }^{87} \mathrm{Sr} /{ }^{86} \mathrm{Sr}$ ratios between 0.7029 and 0.7061 for carbonatites and alkaline rocks from eastern Uganda; the carbonatites average 0.7034 and the associated alkaline rocks average 0.7045 . These differences indicated to them that the rocks are not related solely by magmatic differentiation from a single parent magma. Compared with these data, the Wet Mountains rocks have a considerably narrower range in initial ${ }^{87} \mathrm{Sr} /$ ${ }^{86} \mathrm{Sr}$ ratios, and the carbonatites have ratios comparable with those of nepheline syenite and mafic nephelineclinopyroxene rock.

In summary, samples from the complex at Democrat Creek have distinctly lower initial ${ }^{87} \mathrm{Sr} /{ }^{86} \mathrm{Sr}$ ratios than do those from the McClure Mountain Complex. Within the McClure Mountain Complex, the mafic-ultramafic cumulates and the hornblende-biotite syenites have initial ${ }^{87} \mathrm{Sr}{ }^{86} \mathrm{Sr}$ ratios that are similar, and the nepheline syenites, the mafic nepheline-clinopyroxene rocks, and the carbonatites all have similar ratios. These data 


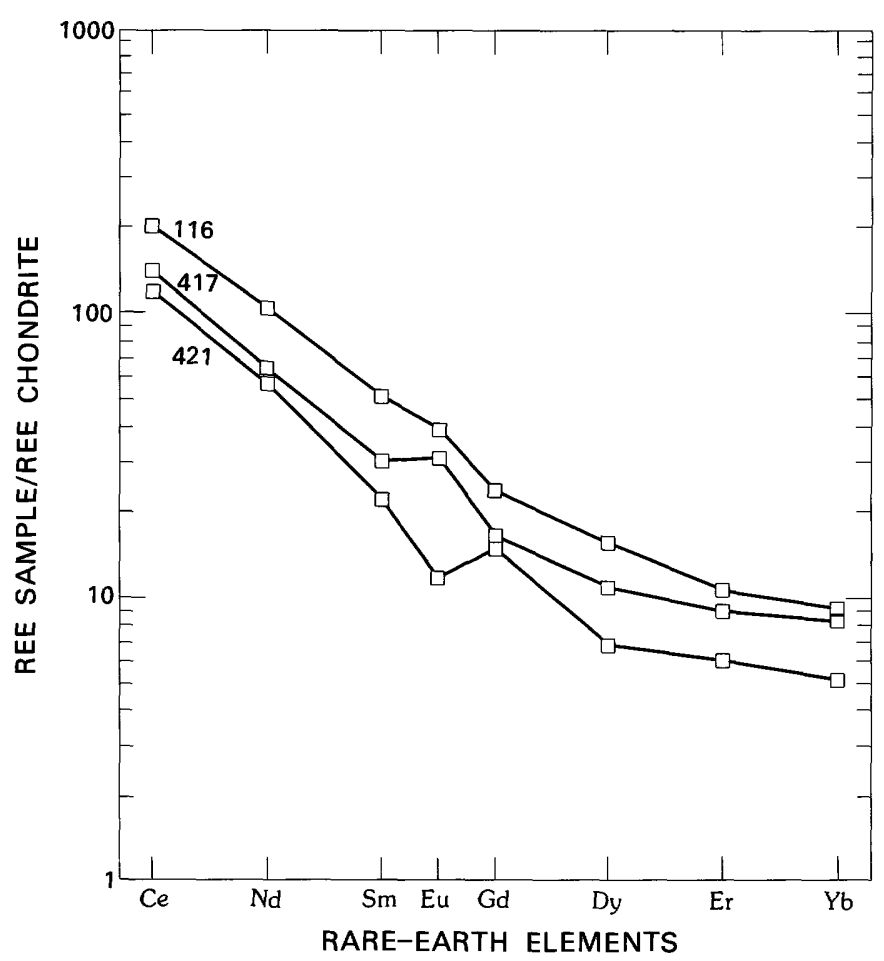

FIGURE 29.-Chondrite-normalized rare-earth-element data for nepheline syenite samples from the McClure Mountain Complex.

suggest that at least three separate magmatic sources, originating in the upper mantle or lower crust, are responsible for the Wet Mountains alkaline rocks.

\section{RUBIDIUM/STRONTIUM RATIOS}

Rubidium and strontium concentrations and $\mathrm{Rb} / \mathrm{Sr}$ ratios (table 9) suggest additional petrologic aspects of these rocks. The rubidium content of the maficultramafic rocks from the McClure Mountain Complex and the complex at Democrat Creek is low. Values range from 1.3 to $5.3 \mathrm{ppm}$. These low values are consistent with a cumulus origin for the mafic-ultramafic rocks at Democrat Creek as well as with those from the McClure Mountain Complex, because rubidium tends to be depleted in plagioclase and pyroxene-the major minerals in these rocks-and is concentrated in the residual melt. The highly variable $\mathrm{Rb} / \mathrm{Sr}$ ratios in quartz syenites in the complex at Democrat Creek range from 4.1 to 27 . This wide range reflects the highly fractionated nature of these rocks. The consistent $\mathrm{Rb} / \mathrm{Sr}$ ratios of the hornblende-biotite syenites in the McClure Mountain Complex range from 0.17 to 0.18 , and suggest that these rocks are not fractionated. The $\mathrm{Rb} / \mathrm{Sr}$ ratios of nepheline syenite and mafic nepheline-clinopyroxene rocks also tend to be somewhat variable.

Figure 32 shows the distribution of rubidium and strontium values for rocks of the McClure Mountain

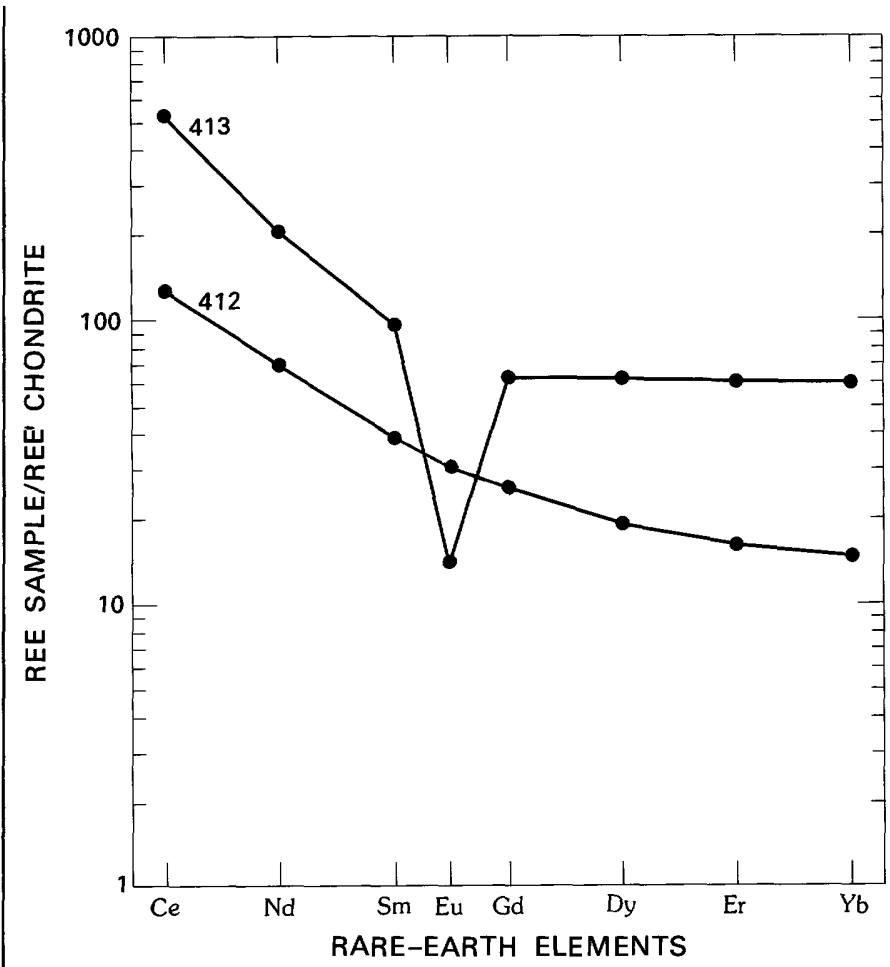

FIGURE 30.-Chondrite-normalized rare-earth-element data for quartz syenite samples from the complex at Democrat Creek.
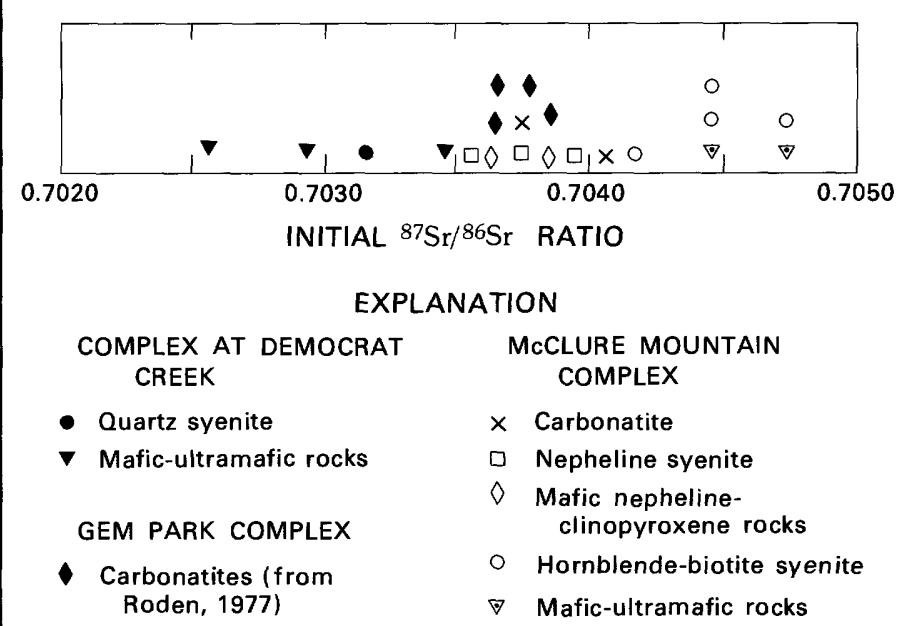

FIGURE 31.-Distribution of initial ${ }^{87} \mathrm{Sr} /{ }^{86} \mathrm{Sr}$ ratios for alkaline rocks of the Wet Mountains area.

Complex. The plotting of the mafic rocks below the $\mathrm{Rb}-$ $\mathrm{Sr}$ diagonal is a consequence of their cumulus originthe liquid remaining after the removal of pyroxenes and plagioclase would contain proportionately more rubidium than the resulting cumulus rocks. Figure 32 also shows that three of the nepheline syenites and the mafic nepheline-clinopyroxene rocks lie on or near the $\mathrm{Rb}-\mathrm{Sr}$ diagonal, indicating that the $\mathrm{Rb} / \mathrm{Sr}$ ratios of these rocks are similar to those of the material from which they were derived. The fourth nepheline syenite and a sample of red syenite lie on a line that is a trend of $\mathrm{Rb}-\mathrm{Sr}$ 


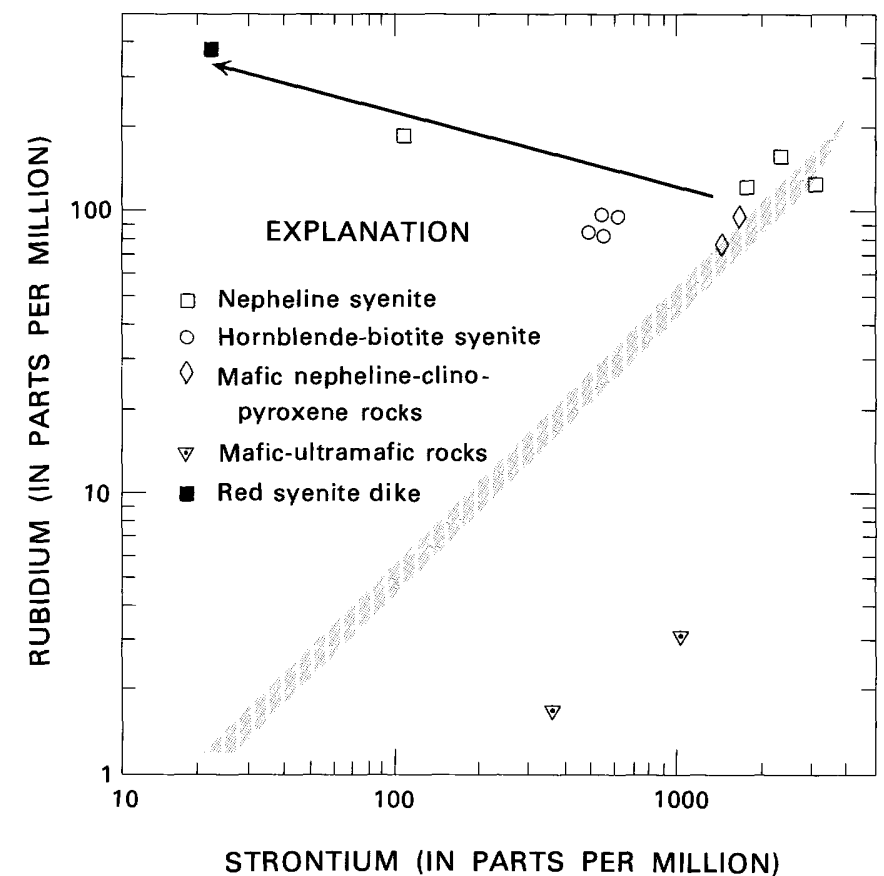

FIGURE 32.-Rubidium/strontium ratios of rocks from the McClure Mountain Complex. Patterned area represents approximate $\mathrm{Rb} / \mathrm{Sr}$ ratios required to yield observed ${ }^{87} \mathrm{Sr} /{ }^{86} \mathrm{Sr}$ ratios.

values best developed by fractionation of nephelinebearing rocks. The hornblende-biotite syenites homogeneously possess higher $\mathrm{Rb} / \mathrm{Sr}$ ratios than their calculated parent and do not lie on the $\mathrm{Rb}-\mathrm{Sr}$ diagonal.

Figure 33 shows the $\mathrm{Rb} / \mathrm{Sr}$ ratios of rocks from the complex at Democrat Creek. The fact that the mafic-ultramafic rocks again plot below the $\mathrm{Rb}$-Sr diagonal suggests a cumulus origin for these rocks also. No rocks have $\mathrm{Rb} / \mathrm{Sr}$ ratios that plot near the $\mathrm{Rb} / \mathrm{Sr}$ diagonal, and thus a complicated process is required to increase the $\mathrm{Rb} / \mathrm{Sr}$ ratios of the quartz syenites to more than those of the calculated parent magma-rocks reflecting this process, if present, have not been identified in this study. The distribution of $\mathrm{Rb} / \mathrm{Sr}$ ratios in the quartz syenites shows a more or less progressive decrease in strontium that suggests fractionation through removal of plagioclase. This fractionation as also suggested by the REE data (fig. 30).

\section{PETROLOGIC CONCLUSIONS}

The mafic-ultramafic cumulus rocks from the McClure Mountain and Gem Park Complexes typically contain normative nepheline and normative olivine but lack normative quartz and normative hypersthene. This assemblage is characteristic of alkali basalt types. The mafic-ultramafic rocks from the complex at Democrat Creek contain abundant normative hypersthene but lack normative nepheline and normative quartz. This

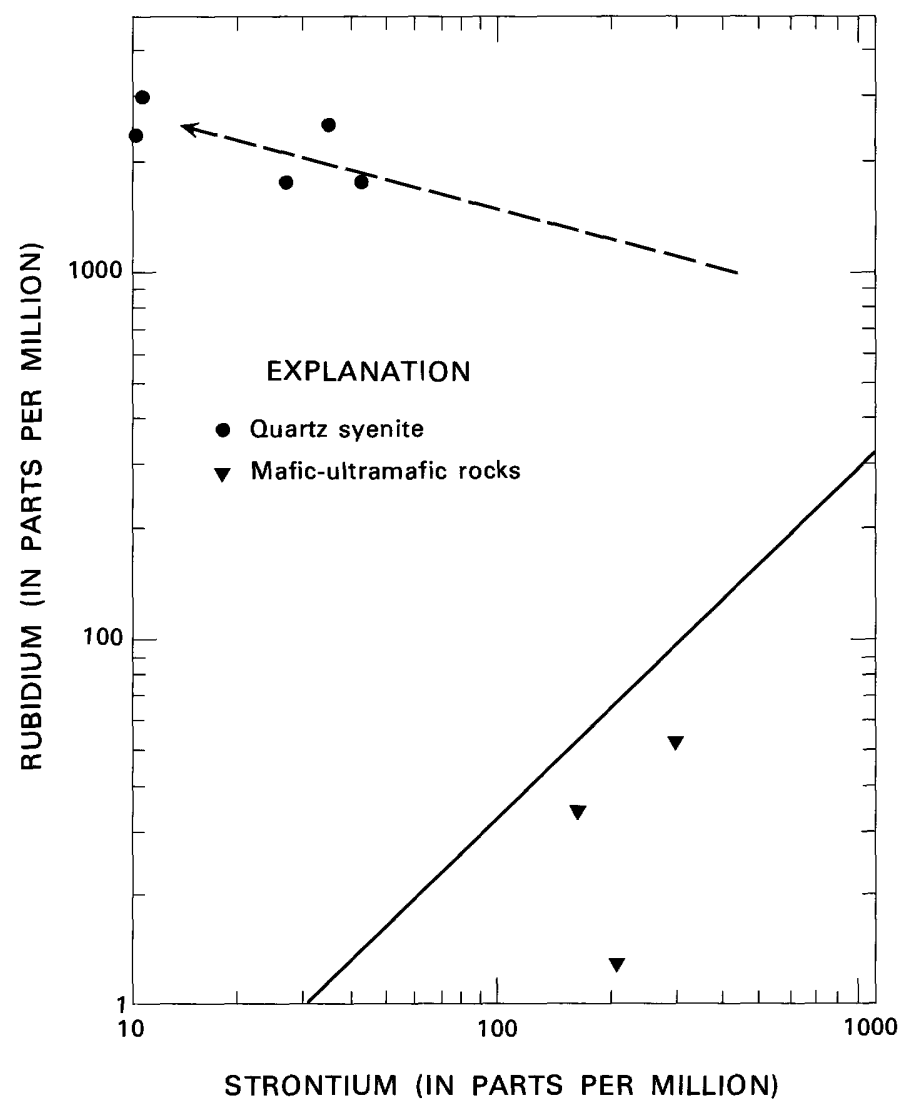

FIGURE 33.-Rubidium/strontium ratios of rocks from the complex at Democrat Creek. Solid line indicates approximate $\mathrm{Rb} / \mathrm{Sr}$ ratios required to yield observed ${ }^{87} \mathrm{Sr} /{ }^{86} \mathrm{Sr}$ ratios. Dashed line indicates fractionation.

assemblage is characteristic of saturated tholeitic basalt types. Minor-element contents of maficultramafic rocks of the complex at Democrat Creek are similar to those of alpine-type ultramafic rocks and ultramafic rocks of layered calc-alkaline intrusions. Minor-element contents of mafic-ultramafic cumulus rocks from the McClure Mountain and Gem Park Complexes are similar; they have characteristics of the more silica-saturated alpine-type ultramafic rocks and ultramafic rocks of layered calc-alkaline intrusions, as well as of some of the strongly silica-undersaturated alkaline ultramafic rocks.

The hornblende-biotite syenites and the nepheline syenites from the McClure Mountain Complex contain normative nepheline and thus lack normative quartz. The quartz syenites from the complex at Democrat Creek contain abundant normative quartz but lack normative nepheline. The hornblende-biotite syenites contain normative $\mathrm{Ab}>\mathrm{Or}>\mathrm{An}$, the nepheline syenites contain normative $\mathrm{Or}>\mathrm{Ab}>\mathrm{An}$, and the quartz syenites contain only normative $\mathrm{Ab}>\mathrm{Or}$. The quartz syenites contain normative hypersthene, but the other syenites do not. The hornblende-biotite syenites and nepheline 

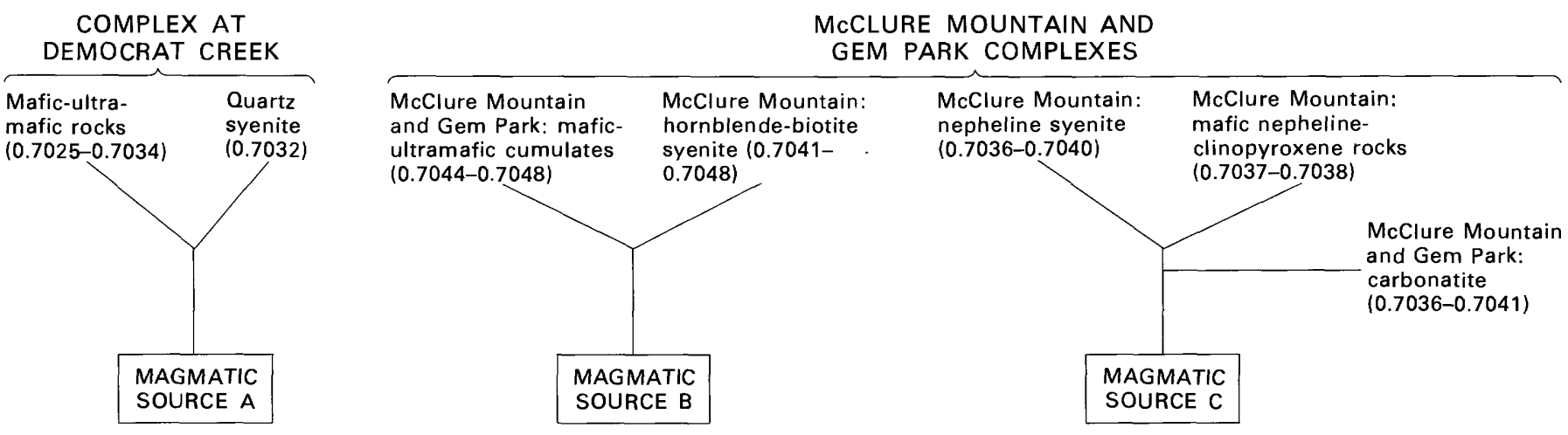

Figure 34.-Grouping according to initial ${ }^{87} \mathrm{Sr} /{ }^{86} \mathrm{Sr}$ ratios (values in parentheses) of rock types of alkaline complexes in the Wet Mountains area.

syenites are chemically undersaturated; this is indicated by the presence of normative olivine as well as normative nepheline. The quartz syenites lack normative olivine as well as normative nepheline. Minor-element contents are considerably different among the several types of syenites. The quartz syenites contain a suite of elements characteristic of agpaitic nepheline syenites, even though they possess none of the other traits of these rocks. The quartz syenites are also deficient in those elements typically concentrated in the maficmineral assemblage of a rock. The major- and minorelement contents of the mafic nepheline-clinopyroxene rocks are similar to those of alkaline mafic and ultramafic rocks.

The significant differences in age, mineralogy, chemistry, and initial ${ }^{87} \mathrm{Sr} /{ }^{86} \mathrm{Sr}$ ratios between the McClure Mountain Complex and the complex at Democrat Creek point out the fundamental genetic differences between the two complexes.

How much time might have been involved in the emplacement of the various rock types of the McClure Mountain Complex is not known, but the differences in initial ${ }^{87} \mathrm{Sr} /{ }^{86} \mathrm{Sr}$ ratios and minor element geochemistry require at least two source materials. The nepheline syenites and the carbonatites have similar ${ }^{87} \mathrm{Sr} /{ }^{86} \mathrm{Sr}$ ratios; therefore, they possibly were derived from the same source, and their profound differences in chemistry and mineralogy are possibly due to some process such as liquid immiscibility.

Initial ${ }^{87} \mathrm{Sr} /{ }^{86} \mathrm{Sr}$ ratios of the hornblende-biotite syenites and the mafic-ultramafic rocks are similar, but are distinct from those of the nepheline syenites. A genetic relationship between the hornblende-biotite syenites and the mafic-ultramafic rocks is possible, but such a hypothesis cannot be tested rigorously because the necessary intermediate rocks are not available for study. Mafic-ultramafic rocks are cumulates. Their extremely mafic mineralogy and their trace-element geochemistry indicate that they are cumulates of a more mafic magma than are the hornblende-biotite syenites. The hornblende-biotite syenites possibly fractionated from this mafic magma. The rather high $\mathrm{Rb} / \mathrm{Sr}$ ratios of the hornblende-biotite syenites are consistent with such a process, but the positive europium anomalies are not.

The hornblende-biotite syenites have lower strontium contents than do the nepheline syenites but higher initial ${ }^{87} \mathrm{Sr} /{ }^{86} \mathrm{Sr}$ ratios. Therefore, the hornblende-biotite syenites possibly were derived from the nepheline syenites with the addition of radiogenic ${ }^{87} \mathrm{Sr}$ from the Precambrian wall rocks. This hypothesis could explain the data, however, only if significant fractional crystallization that lowered the strontium content occurred together with the assimilation that raised the ${ }^{87} \mathrm{Sr} /{ }^{86} \mathrm{Sr}$ ratio. Fractional crystallization that would greatly lower the strontium content would have to involve plagioclase; plagioclase removal would produce negative europium anomalies, whereas the hornblende-biotite syenites actually have positive europium anomalies.

The only mechanism that can be envisioned for the genesis of the hornblende-biotite syenites that would be compatible with their high $\mathrm{Rb} / \mathrm{Sr}$ ratios and positive europium anomalies is that the syenites represent essentially primary magmas formed by a partial melting process that left a residue rich in pyroxene. The pyroxene would retain significant strontium but would not have a relative preference for europium.

Apparently a minimum of three distinct source materials and several geologic processes were necessary to produce the major alkaline rock types observed in the Wet Mountains area. This complicated situation is diagramed in figure 34. Only one source material is necessary to form the rocks of the complex at Democrat Creek, and the rock types there might be simply described as products of fractional crystallization. The hornblende-biotite syenites of the McClure Mountain Complex and the mafic-ultramafic rocks of the McClure Mountain and Gem Park Complexes ultimately may have been derived from the same source material, but 
mafic-ultramafic rocks are cumulates from a basaltic magma that was probably not directly related to the hornblende-biotite syenite magma. Similarly, the nepheline syenites and the carbonatites might have been derived from the same source material.

The source materials for the alkaline rocks in the Wet Mountains area might have been rocks that differed in basaltic compositions. A gabbro of tholeiitic composition would be a suitable source material for the rocks of the complex at Democrat Creek. A more alkaline gabbro might be a suitable source for the hornblende-biotite syenites of the McClure Mountain Complex, whereas a gabbro of nepheline basalt composition may have been the source of the nepheline syenites. Although this narrative is admittedly speculative, a history of formation at least this complicated is necessary to account for rocks so diverse and so closely related spatially.

\section{REFERENCES CITED}

Armbrustmacher, T. J., 1979, Replacement and primary magmatic carbonatites from the Wet Mountains area, Fremont and Custer Counties, Colorado: Economic Geology, v. 74, no. 4, p. 888-901.

-1980, Major- and minor-element distribution in alkaline rock complexes of the Wet Mountains area, Custer and Fremont Counties, Colorado: Geological Society of America Abstracts with Programs, v. 12, no. 6, p. 266.

Armbrustmacher, T. J., and Banks, N. G., 1974, Clouded plagioclase in metadolerite dikes, southeastern Bighorn Mountains, Wyoming: American Mineralogist, v. 59, p. 656-665.

Armbrustmacher, T. J., and Brownfield, I. K., 1978, Carbonatites in the Wet Mountains area, Custer and Fremont Counties, Colorado-Chemical and mineralogical data: U.S. Geological Survey Open-File Report 78-177, 6 p.

Armbrustmacher, T. J., Brownfield, I. K., and Osmonson, L. M., 1979, Multiple carbonatite at McClure Gulch, Wet Mountains alkalic province, Fremont County, Colorado: Mountain Geologist, v. 16 , no. 2 , p. $37-45$.

Armbrustmacher, T. J., and Hedge, C. E., 1982, Genetic implications of minor-element and Sr-isotope geochemistry of alkaline rock complexes in the Wet Mountains area, Fremont and Custer Counties, Colorado: Contributions to Mineralogy and Petrology, v. 79 , p. $424-435$.

Armbrustmacher, T. J., Hedge, C. E., and Parker, R. L., 1979, Alkaline rock complexes in the Wet Mountains area, Fremont and Custer Counties, Colorado: Genetic implications of minor-element and Sr-isotope geochemistry: Geological Society of America Abstracts with Programs, v. 11, no. 7, p. 380-381.

Becker, R. M., Shannon, S. S., Jr., and Rose, C. K., 1961, Iron Mountain titaniferous magnetite deposit, Fremont County, Colorado: U.S. Bureau of Mines Report of Investigations 5864, $18 \mathrm{p}$.

Bell, Keith, and Powell, J. L., 1970, Strontium isotopic studies of alkalic rocks - the alkalic complexes of eastern Uganda: Geological Society of America Bulletin, v. 81, p. 3481-3490.

Brock, M. R., and Singewald, Q. D., 1968, Geologic map of the Mount Tyndall quadrangle, Custer County, Colorado: U.S. Geological Survey Geologic Quadrangle Map GQ-596, scale 1:24,000.
Brown, P. E., 1973, A layered plutonic complex of alkali basalt parentage-The Lilloise intrusion, east Greenland: Journal of the Geological Society of London, v. 129, p. 405-418.

Christman, R. A., Brock, M. R., Pearson, R. C., and Singewald, Q. D., 1954, Wet Mountains, Colorado, thorium investigations, 1952-1954: U.S. Geological Survey Trace Elements Investigations Report 354, $52 \mathrm{p}$.

1959, Geology and thorium deposits of the Wet Mountains, Colorado-a progress report: U.S. Geological Survey Bulletin 1072-H, p. 491-535.

Currie, K. L., 1976, The alkaline rocks of Canada: Geological Survey of Canada Bulletin 239, $228 \mathrm{p}$.

Fenton, M. D., and Faure, G., 1970, Rb-Sr whole-rock age determinations of the Iron Hill and McClure Mountain carbonatite-alkalic complexes, Colorado: Mountain Geologist, v. 7, no. 4, p. 269-275.

Gerasimovsky, V. I., 1974, Trace elements in selected groups of alkaline rocks, in Sorensen, H., ed., The alkaline rocks: New York, John Wiley, p. 402-412.

Goles, G. G., 1967, Trace elements in ultramafic rocks, in Wyllie, P. J., ed., Ultramafic and related rocks: New York, John Wiley, p. $352-362$.

Heinrich, E. W., 1966, The geology of carbonatites: Chicago, Rand MeNally, $555 \mathrm{p}$.

Heinrich, E. W., and Alexander, D. H., 1976, Infinite variations on a fenite theme [abs.]: 25th International Geology Congress, $\mathrm{Au}-$ stralia, v. 1, p. 124-125.

- 1979, Geology and petrogenesis of the dike retinue of the McClure Mountain mafic-alkalic complex, Colorado, U.S.A. [abs.]: Geological Association of Canada-Mineralogical Association of Canada annual meeting, Program with Abstracts, v. 4, p. 56.

Heinrich, E. W., and Dahlem, D. H., 1966, Carbonatites and alkalic rocks of the Arkansas River area, Fremont County, Colorado: Mineralogical Society of India, IMA volume, p. 37-44.

- 1967, Carbonatites and alkalic rocks of the Arkansas River area, Fremont County, Colorado, pt. 4. The Piñon Peak breccia pipes: American Mineralogist, v. 52, p. 817-831.

1969, Dikes of the McClure Mountain-Iron Mountain alkalic complex, Fremont County, Colorado, U.S.A.: Bulletin Volcanologique, v. 33 , p. 960-976.

Heinrich, E. W., and Moore, D. G., Jr., 1970, Metasomatic potash feldspar rocks associated with igneous alkalic complexes: Canadian Mineralogist, v. 10, pt. 3, p. 571-584.

Jackson, E. D., 1961, Primary textures and mineral associations in the ultramafic zone of the Stillwater Complex, Montana: U.S. Geological Survey Professional Paper 358, 106 p.

Jaffe, H. W., Gottfried, David, Waring, C. L., and Worthing, H. W., 1959, Lead-alpha age determinations of accessory minerals of igneous rocks (1953-1957): U.S. Geological Survey Bulletin 1097-B, p. B65-B148.

Kay, R. W., and Gast, P. W., 1973, The rare earth content and origin of alkali-rich basalts: Journal of Geology, v. 81 , no. $6, p$. $653-682$.

Lazarenkov, V. G., 1978, Differences in trace-element composition between effusive and intrusive alkalic rocks: Geochemical International, v. 15 , no. 4 , p. $80-83$.

LeBas, M. J., 1977, Carbonatite-nephelinite volcanism-An African case history: London, John Wiley, $347 \mathrm{p}$.

MacDonald, G. A., and Katsura, T., 1964, Chemical composition of Hawaiian lavas: Journal of Petrology, v. 5, p. 82-133.

Olson, J. C., and Marvin, R. F., 1971, Rb-Sr whole-rock age determinations of the Iron Hill and McClure Mountain carbonatite-alkalic complexes, Colorado-Discussion: Mountain Geologist, v. 8, no. 4, p. 221 . 
Olson, J. C., Marvin, R. F., Parker, R. L., and Mehnert, H. H., 1977, Age and tectonic setting of lower Paleozoic alkalic and mafic rocks, carbonatites, and thorium veins in south-central Colorado: U.S. Geological Survey Journal of Research, v. 5, p. 673-687.

Parker, R. L., Adams, J. W., and Hildebrand, F. A., 1962, A rare sodium niobate mineral from Colorado, in Geological Survey research 1962: U.S. Geological Survey Professional Paper 450-C, p. C4-C6.

Parker, R. L., and Hildebrand, F. A., 1963, Preliminary report on alkalic intrusive rocks in the northern Wet Mountains, Colorado, in Geological Survey research 1962: U.S. Geological Survey Professional Paper 450-E, p. E8-E10.

Parker, R. L., and Sharp, W. N., 1970, Mafic-ultramafic igneous rocks and associated carbonatites of the Gem Park Complex, Custer and Fremont Counties, Colorado: U.S. Geological Survey Professional Paper 649, 24 p.

Powell, J. L., and Bell, Keith, 1970, Strontium isotopic studies of alkalic rocks-Localities from Australia, Spain, and the western United States: Contributions to Mineralogy and Petrology, v. 27, p. 1-10.

Rock, N. M. S., 1976, The role of $\mathrm{CO}_{2}$ in alkali rock genesis: Geological Magazine, v. 113, p. 97-113.

Roden, M. K., 1977, Rare earth elements distributions and strontium isotopic data from the Gem Park igneous complex, Colorado: Kansas State University M. S. thesis, 103 p.

Roden, M. K., and Cullers, R. L., 1976, Rare earth element distributions and strontium isotope data from the Gem Park igneous complex, Colorado: Geological Society of America Abstracts with Programs, v. 8, no. 5, p. 622-623.

Scott, G. R., and Taylor, R. B., 1975, Post-Paleocene Tertiary rocks and Quaternary volcanic ash of the Wet Mountain Valley, Colorado: U.S. Geological Survey Professional Paper 868, 15 p.
Scott, G. R., Taylor, R. B., Epis, R. C., and Wobus, R. A., 1976, Geologic map of the Pueblo $1^{\circ} \times 2^{\circ}$ quadrangle, south-central Colorado: U.S. Geological Survey Miscellaneous Field Studies Map MF-775, scale 1:187,500.

Shawe, D. R., and Parker, R. L., 1967, Mafic-ultramafic layered intrusion at Iron Mountain, Fremont County, Colorado: U.S. Geological Survey Bulletin 1251-A, p. A1-A28.

Singewald, Q. D., and Brock, M. R., 1956, Thorium deposits in the Wet Mountains, Colorado: U.S. Geological Survey Professional Paper 300, p. 581- 585.

Sorensen, H., 1974a, Introduction, in Sorensen, H., ed., The alkaline rocks: New York, John Wiley, p. 15-22.

Sorensen, H., 1974b, Alkali syenites, feldspathoidal syenites, and related lavas, in Sorensen, H., ed., The alkaline rocks: New York, John Wiley p. 22-52.

Taylor, R. B., Scott, G. R., Wobus, R. A., and Epis, R. C., 1975a, Reconnaissance geologic map of the Cotopaxi 15-minute quadrangle, Fremont and Custer Counties, Colorado: U.S. Geological Survey Miscellaneous Investigations Series Map I-900, scale $1: 62,500$.

-1975b, Reconnaissance geologic map of the Royal Gorge quadrangle, Fremont and Custer Counties, Colorado: U.S. Geological Survey Miscellaneous Investigations Series Map I-869, scale $1: 62,500$.

Wager, L. R., and Brown, G. M., 1967, Layered igneous rocks: Edinburgh, Oliver and Boyd, $588 \mathrm{p}$.

Wedepohl, K. E., 1971, Geochemistry: New York, Holt, Rinehart, and Winston, 231p.

Wilkinson, J. F. G., 1974, The mineralogy and petrography of alkali basaltic rocks, in Sorensen, $H$. ed., The alkaline rocks: New York, John Wiley, p. 67-95. 